\title{
REFORMAS DA INTERNACIONALIZAÇÃO DOS CURSOS SUPERIORES NO BRASIL
}

\section{REFORMS OF THE INTERNATIONALIZATION OF HIGHER COURSES IN BRAZIL}

\author{
GERVASIO, Cirlene Ferreira Neri ${ }^{1}$ \\ FONTENELE, Adelaine Aparecida Viana ${ }^{2}$ \\ SOUZA, Allessandra Cândido Ciza de ${ }^{3}$ \\ SOUZA, Ana Maria Reis de ${ }^{4}$
}

\begin{abstract}
Resumo
Objetivos: $O$ presente artigo tem como intuito analisar o cenário gerado pela internacionalização da educação superior bem como os novos papeis atribuídos às universidades no contexto da reforma da educação superior. Metodologia: A pesquisa recorreu ao método qualitativo, onde buscou subsídios em várias fontes publicadas onde foi feita uma breve fundamentação teórica e análise sobre a reforma da educação superior, a concepção da universidade e o seu papel social bem como a internacionalização propriamente dita e as intenções existentes por trás desta. Além disso, evidencia-se os pontos positivos e negativos deste processo dentro do contexto social brasileiro, destacando as melhorias a serem realizadas. Conclusão: enfatizar a necessidade da relação direta entre estratégias acadêmicas e inserção social para que, em processos como estes que envolvem a saída de estudantes para expandir a educação superior brasileira, não se restrinja àqueles que possuem maior renda e, sim, àqueles que de fato estão capacitados a representar o Brasil e intercambiar conhecimentos científicos, experiências culturais e aprendizados sociais.
\end{abstract}

Palavras-chave: Internacionalização. Instituições de Ensino Superior. Reforma educacional.

\section{Abstract}

Objectives: This article aims to analyze the scenario generated by the internationalization of higher education as well as the new roles attributed to universities in the context of higher education reform. Methods: The research used the qualitative method, which sought subsidies from various published sources where a brief theoretical foundation and analysis was made about the reform of higher education, the conception of the university and its social role as well as the internationalization itself and the intentions behind it. Furthermore, the positive and negative points of this process within the Brazilian social context are highlighted, highlighting the improvements to be made. Conclusion: emphasize the need for a direct relationship between academic strategies and social insertion so that, in processes like these that involve students leaving to expand Brazilian higher education, it is not restricted to those who have higher income, but to those who in fact they are able to represent Brazil and exchange scientific knowledge, cultural experiences and social learning.

Keywords: Internationalization. Higher education institutions. Educational reform.

\footnotetext{
${ }^{1}$ Pedagogia UFMG, mestranda Universidad de la Empresa - UDE, Uruguai.

${ }^{2}$ Pedagogia FISBI, mestranda Universidad de la Empresa - UDE. Uruguai.

${ }^{3}$ Pedagogia UERJ, mestranda Universidad de la Empresa - UDE. Uruguai.

${ }^{4}$ Pedagogia UNIVILA, mestranda Universidad de la Empresa - UDE. Uruguai.

RCMOS - Revista Científica Multidisciplinar O Saber. ISSN: 2675-9128. São Paulo, v. 02, n. 2, p. 01-10, fev. 2021
} 


\section{Introdução}

Por direitos humanos pode-se classificar os direitos e liberdades fundamentais relativos à garantia da vida digna a todas as pessoas, sendo que estes compostos por direitos civis e políticos (CUMPER, 2003). De acordo com a Declaração Universal dos Direitos Humanos (DUDH) da Organização das Nações Unidas (ONU), "Todos os seres humanos nascem livres e iguais em dignidade e em direitos. Dotados de razão e de consciência, devem agir uns para com os outros em espírito de fraternidade."

Segundo Beetham (1998), os direitos humanos são constituintes da democracia, regime político em que os cidadãos elegíveis participam de forma igualitária a partir de atuação direta ou indireta. A efetividade dos direitos e liberdades básicas é conditio sine qua non para que as pessoas possam atuar ativamente frente às demandas públicas sem que haja controle popular por parte dos governantes. Apesar da estreita relação e mútua dependência entre direitos humanos e democracia, esta não se faz de forma simplificada e se mostra carregada de situações onde a violação dos direitos traz limitação à expressão democrática.

Conforme afirmativa de Sguissard (2009), dentre os direitos fundamentais, pode-se citar a educação. Esta é peça constituinte da democracia e possui alto nível de consolidação e expansão dos conceitos atrelados aos direitos humanos, sendo essencial para a permanência da sociedade igualitária, civil e politicamente. A educação é um direito de todos, independentemente de situação financeira, social, local de moradia, dentre outros aspectos.

Diante do pano de fundo da importância da educação para a formação de uma nação, vê-se, ao longo da história brasileira, iniciativas por parte do governo federal no intuito de aprimorar o sistema educacional, principalmente no que tange à formação superior. Dentre essas medidas, ao longo dos anos de 2012 e 2018, pode-se citar a iniciativa por parte do Ministério da Educação, Ministério das Relações Exteriores e Ministério da Ciência, Tecnologia, Inovações e Comunicação na atuação como fomentador do processo de internacionalização da Educação, Ciência e Tecnologia brasileiras por intermédio das Instituições de Ensino Superior (IES) (SAVIANI, 2007).

Audi e Morosini (2010) afirmam que, por meio de programas apoiados pelo governo federal, gerou-se fluidez acadêmica internacional na graduação e na pós-graduação com o intuito do intercâmbio de conhecimentos e pesquisas. Nesse contexto, dá-se grande destaque ao 
Programa Ciência sem Fronteiras, instituído através do Decreto n. ${ }^{\circ} 7.642$ de 13 de dezembro de 2011, responsável pela intensificação do processo de internacionalização do Ensino Superior e configurando este como um fenômeno complexo e peculiar.

Pelo viés acadêmico, os debates sobre o tema demandam, previamente, a compreensão aprofundada sobre o assunto bem como sobre as consequências dos fatos recentes. Assim, com o intuito de estudar as premissas e debater o processo de internacionalização do Ensino Superior brasileiro, o presente artigo traz uma breve discussão sobre a reforma da educação superior, a redefinição do entendimento sobre a Universidade, a internacionalização do ensino superior propriamente dita, as políticas atreladas à internacionalização bem como as implicações geradas por esse processo.

Optar pela pesquisa bibliográfica, para Diascânio (2020, p.98), "É se propor a gerar novos conhecimentos, baseando-se nos processos mentais de análise, síntese, comparação e confrontamentos sobre as teorias existentes, identificando nas bases teóricas existentes as possíveis respostas para o problema científico da investigação".

Constitui-se em um método de pesquisa qualitativa que possibilita o entendimento de diferentes concepções sobre um determinado tema, pensado de forma coletiva num dado contexto e momento histórico (NEVES, 1996). Com esta técnica o pesquisador pode intensificar o acesso às informações sobre determinado fenômeno, seja pela intenção de gerar tantas possibilidades ou pela averiguação de uma ideia em profundidade. Portanto, a pesquisa é de caráter exploratório, e bibliográfico. Segundo Furaste (2006, p.38) a pesquisa exploratória "busca apenas mais informações sobre o que está sendo estudado". "A pesquisa qualitativa sugere a introdução no campo das ciências sociais como mecanismo que intervém sobre o fenômeno em toda a sua instância" (DIASCÂNIO, 2020, p.85).

\section{Fundamentação teórica}

\subsection{Ensino superior}

Conforme Vygotsky, Luria \& Leontiev (1992), o ensino é uma construção de conhecimentos através da participação e da interação com a sociedade. As Instituições de Ensino Superior - IES, segundo as Leis das Diretrizes e Bases de Educação Nacional - LDB 
(Lei n. 9.394/96), tem como finalidade "formar diplomados nas diferentes áreas de conhecimento, aptos para inserção em setores profissionais e para a participação no desenvolvimento da sociedade brasileira e colaborar na sua formação continua", sendo que é por meio dos currículos dos cursos que as IES definem o conjunto de disciplinas, organizando as em uma sequência lógica de conteúdos visando atender as necessidades e expectativas da sociedade em relação ao indivíduo que formam (TCHEOU, 2002).

A exigência de profissionais mais qualificados, por parte das empresas, desloca o eixo da formação, no caso contábil, para a necessidade de novas competências relacionadas com a inovação, a criatividade e a capacidade funcional. Portanto, ocorre uma alteração na estrutura de contratações que passam a requerer trabalhadores com um nível de educação, qualificação e experiência mais elevados.

De acordo com Souza (2006), inúmeras críticas têm sido feitas acerca do perfil dos graduados em contabilidade, gerando movimentos em favor de mudanças, tanto nos currículos como nas técnicas pedagógicas consideradas ultrapassadas, a fim de corrigir as deficiências dos cursos ofertados pelas Instituições de Ensino, possibilitando a formação de profissionais competitivos e competentes.

Sabe-se que o mercado de trabalho está a cada dia mais competitivo, pois a globalização causou uma revolução no campo tecnológico e têm despertado uma preocupação em todas as profissões e, consequentemente, em seus profissionais, surgindo assim à necessidade de investir na formação dos alunos e professores para atuarem nessa nova demanda que a sociedade exige.

Portanto, a formação do profissional no ensino superior passa por muitas etapas que se complementa, não se dissociando a teoria da prática e a orientação com bases pedagógicas, pois as formas de aprendizagem não devem ser esquecidas durante a vida escolar do aluno, não importando a etapa de formação que frequenta.

Outro fator que deve ser valorizado é a atual situação econômica do país, as frequentes oscilações e todo o processo de mudança, pois estabelecem, através do mercado de trabalho, novas exigências e necessidades profissionais de um modo geral. 


\subsection{Reforma da educação superior e redefinição nos fins da universidade}

De acordo com Lima et al. (2008), no Brasil, pode-se notar fortes modificações nas IES, principalmente, entre os anos 2003 e 2010 na gestão Luiz Inácio Lula da Silva em que houve grande proximidade com o movimento global de alteração do ensino superior, através, principalmente, do Processo Bolonha (tradução livre do original Bolong Process) que atingiu diversos países europeus. Esta fase foi marcada por características atinentes às premissas do Processo Bolonha, as quais seguem listadas na Tabela 1.

Tabela 1: Características notadas nas IES.

\begin{tabular}{|c|c|}
\hline ASPECTO GERAL & DESCRIÇÃO \\
\hline $\begin{array}{l}\text { AVALIAÇÃ̈O E } \\
\text { REGULAÇÃAO }\end{array}$ & $\begin{array}{l}\text { Centralidade dos sistemas de avaliação e regulação, que promove maior } \\
\text { rankeamento e a competitividade entre as IES; }\end{array}$ \\
\hline PARCERIAS & Maior incentivo à parceria universidade - setor produtivo; \\
\hline GESTÃO & Adoção de mecanismos de gestão estratégica ou gerencial; \\
\hline \multirow{4}{*}{$\begin{array}{l}\text { ABRANGÊNCIA } \\
\text { SOCIAL }\end{array}$} & Diversificação de cursos e de IES; \\
\hline & $\begin{array}{l}\text { Estabelecimento de metas para ampliar vagas, aumentar a relação } \\
\text { professor-aluno e diminuir o custo-aluno nas universidades públicas federais; }\end{array}$ \\
\hline & Ampliação dos cursos e das vagas mediante educação superior a distância; \\
\hline & $\begin{array}{l}\text { Criação e ampliação de sistemas de concessão de bolsas para estudantes } \\
\text { pobres em IES privadas. }\end{array}$ \\
\hline
\end{tabular}

Fonte: elaborada pelo autor a partir do Bologna Process (2013)

De acordo com Santos (2004), uma das teorias a respeito das alterações lançadas às IES, eram que estas faziam parte de uma série de estratégias para que o Brasil assumisse um posicionamento de destaque internacional quanto à qualidade do ensino universitário, quando comparado a países latino-americanos e africanos.

Assim, a transnacionalização da educação superior passou a corroborar com o avolumamento desse nível educacional tanto regionalmente como globalmente gerando alterações tanto no papel da universidade na sociedade como internamente a estas através da compatibilização curricular com cursos do exterior, destaque institucional, melhoria na metodologia de avaliação e no processo de gestão bem como das redes de pesquisas.

As medidas tomadas ao longo do governo Lula foram consequências diretas daquelas iniciadas pelo Fernando Henrique Cardoso - FHC (1995 - 2002), sendo estas orientadas pelo 
Banco Mundial, através de ações que visavam os seguintes pontos: incentivo à diversidade $\mathrm{e}$ distinção dos cursos superiores; adoção de programas educacionais à distância; diversificação das procedências dos aportes financeiros; implementação de processos de financiamentos de cunho estatal em conformidade com a performance esperada; melhoria e a aproximação entre professor e aluno; combate à saída precoce de alunos; combate às dependências nas disciplinas; exigência a maior transparência quanto aos gastos feitos com dinheiro público; o incentivo às pesquisas na tentativa de alinhar as demandas do mercado com os conteúdo ensinados em sala de aula; a promoção de políticas afirmativas para propiciar um maior acesso dos grupos prioritários; e, por fim, a instituição e o fortalecimento de reduções de mensalidades nas universidades privadas (SANTOS, 2004).

\subsection{Internacionalização do ensino superior}

De acordo com Morisini (2011), é possível destacar três possibilidades geradas pela transnacionalização da educação superior: a dimensionalidade internacional existente desde o século XX, censo está marcada pela incidência desconexa entre os programas; a educação internacional, propriamente dita, elaborada com finalidades políticas; e, por fim, a internacionalização da educação atrelada ao processo de globalização social e econômica, processo gerador de grandes impactos na educação superior.

Pode-se notar ao analisar obras a respeito do tema abordado que, muitos autores usam o conceito de internacionalização para se referir à globalização. Apesar disso, segundo Altbach e Knight (2007), deve-se atentar que estes são conceitos distintos: a globalização está ligada a tendência mundial gerada pelos processos capitalistas, principalmente ao longo do século XXI marcado pelo Estado mínimo e pela conscientização de parte da sociedade sobre a importância da educação superior. Já a internacionalização se refere ao grupo de políticas focados no sistema acadêmicos focadas na transnacionalização deste ambiente fazendo com que este não se limite às paredes da universidade e atinja patamares mundiais.

O Brasil, apesar de ter se inserido no contexto da globalização desde o início de sua história produtiva, aderiu aos ideais da internacionalização, como já citado, apenas na década a partir do Governo FHC, cuja continuidade foi marcada pela atuação intensa do governo federa. 
O Plano Nacional de Educação mais recente, que data o ano de 2014, estabelece dentre suas vinte metas propostas que três correspondam à internacionalização da educação superior:

Meta 12.12) Consolidar e ampliar programas e ações de incentivo à moblidade estudantil e docentes em cursos de graduação e pós graduação, em âmbito nacional e internacional, tendo em bist o enriquecientos da formação de nível superior, (...)

Meta 13.7) Fomentar a formação de consórcios entre IES públicas, com vistas a potencializar a atuação regional, inclusive por meio de plano de desenvolvimento institucional integrado, assegurando maior visibilidade nacional e internacional às aqtividades de ensino, pesquisa e extensão.

Meta 14,9) Consolidar programas, projetos e ações que objetivem a internacionalização da pesquisa e da pós graduação brasileiras. Incentibando a atuação em rede e o fortalecinento de grupos de pesquisa (PNE, 2014)

Diferentemente da globalização, processo contínuo e que não pode ser controle, a internacionalização depende de uma série de fatores que envolvem a decisão dos detentores do poder como consequência de interesses diversos, como por exemplo, a necessidade de melhoria do padrão de qualidade e de confiabilidade atreladas às IES (ALTBACH E KNIGHT, 2007).

\subsection{Implicações da internacionalização do ensino superior}

Oliveira (2000) afirma que a internacionalização do ensino superior pode auxiliar de forma direta a qualificação da mão de obra brasileira, sendo este um dos principais argumentos, por exemplo, da gestão Dilma Rousseff diante o Programa Ciência Sem Fronteiras. A ideia é que o estudante retornaria ao Brasil com uma melhor qualificação para atuar no mercado de trabalho em decorrência de todo o aprendizado adquirido na experiência internacional.

Além disso, pode-se notar no discurso do governo federal, que, além das mudanças focadas nas demandas do mercado, espera-se também uma alteração social em decorrência da possibilidade de aberturas de IES dentro do contexto internacional oferecendo maior visibilidade ao que se produz nas universidades brasileiras bem como propiciando um networking social, acadêmico e profissional. Assim, a troca de conhecimentos culturais e pessoais também seria uma forma de incrementar a hospitalidade brasileira e gerar questionamentos diante dos paradigmas da sociedade (OLIVEIRA, 2000).

Apesar dos aspectos positivos citados, de acordo com Nogueira (2008), a internacionalização do ensino superior deve ser feita através de estratégias que superem a barreira do conhecimento fluente em outra língua. Este é um ponto crucial, já que a educação 
básica brasileira não oferece respaldo suficiente para que um indivíduo adquira fluência e, portanto, os programas de saída do país acabam tendo caráter elitista, assim como o ingresso em universidades públicas.

\section{Considerações finais}

No presente artigo, realizou-se as diversas nuances atinentes às reformas educacionais no ensino superior evidenciando a alteração da concepção sobre a universidade e o impacto na internacionalização das IES. Pode-se concluir que as políticas focadas para este fim, possibilitam a fluidez acadêmica internacional na graduação e na pós-graduação, além de propiciar o intercâmbio de conhecimentos e pesquisas.

Apesar disso, pode-se identificar que o espaço científico muitas vezes é reduzido ao canal onde se evidenciam intenções de cunho político e econômico, sem que haja a percepção correta acerca dos impactos sobre a sociedade. Assim, deve-se enfatizar a necessidade da relação direta entre estratégias acadêmicas e inserção social para que, em processos como estes que envolvem a saída de estudantes para expandir a educação superior brasileira, não se restrinja àqueles que possuem maior renda e, sim, àqueles que de fato estão capacitados a representar o Brasil e intercambiar conhecimentos científicos, experiências culturais e aprendizados sociais.

\section{Referências}

AUDY, J; MOROSINI, M. Inovação, Universidade e Internacionalização: boas práticas na PUCRS. EdiPUCRS: Rio Grande do Sul, 2010.

BEETHAM, D. Human rights as a model for cosmopolitan democracy. In: ARCHIBUGI, D.; HELD, D.; KOHLER, M. (Eds.). Re-imagining political community: studies in cosmopolitan democracy. Cambridge: Polity Press, 1998.

\section{BOLOGNA PROCESS. EUROPEAN HIGHER EDUCATION AREA. Ministerial}

Declarations and Communiqués. Apresenta documentos sobre o Espaço Europeu de Ensino Superior. Disponível em: http://www.ehea.info/article-details.aspx?ArticleId=80. Acesso em: 25 fev. 2021. 
CUMPER, P. Direitos humanos: a história, desenvolvimento e classificação. In: HEGARTHY, A.; LEONARD, S. Direitos humanos. Uma agenda para o século XXI. Lisboa: Instituto Piaget, p. 21-34, 2003.

DIASCÂNIO, J. M. Etapas da pesquisa cientifica. Rio de Janeiro: Autobiografia, 2020.

FURASTÉ, P. A. Normas técnicas para trabalho cientifico: elaboração e formatação. 14. ed. ampl. e atual. Porto Alegre: [S. n.], 2006.

NEVES, J. L. Pesquisa qualitativa - características, uso e possibilidades. Cadernos de pesquisa em administração, São Paulo. v. 1, n. 3, 2. sem. 1996.

NOGUEIRA, M. A.; AGUIAR, A. M. S.; RAMOS, V. C. C. Fronteiras desafiadas: a internacionalização das experiências escolares. Educação e Sociedade. Campinas, v. 29, n. 103, p. 355-76, mai./ago. 2008.

OLIVEIRA, J. F. A reestruturação da educação superior no Brasil no processo de Nuances: estudos sobre Educação. Ano XVII, v. 17, n. 18, p. 50-67, jan./dez. 2010. Metamorfose das universidades federais: o caso da UFG. 2000. Tese (Doutorado em Educação). Faculdade de Educação, Universidade de São Paulo, São Paulo, 2000.

PORTUGAL. Ministério da Ciência, Tecnologia e Ensino Superior. Processo de Bolonha. Disponível em: https://ec.europa.eu/education/policies/higher-education/bologna-process-andeuropean-higher-education-area_pt. Acesso em: 11 jan. 2020.

PORTUGAL. Lei Federal 13.005, de 25 de junho de 2014. Aprova o Plano Nacional de Educação - PNE e dá outras providências. Brasília, DF, 25. jun. 2014.

LIMA, L.; AZEVEDO, M. L. N.; CATANI, A. M. O processo de Bolonha, a avaliação da educação superior e algumas considerações sobre a universidade nova. Avaliação, Campinas; Sorocaba, v. 13, n. 1, p. 7-36, mar. 2008. Disponível em: https://ape.unesp.br/pdi/execucao/artigos/avaliacao/a02v13n1.pdf. Acesso em: 07 ago. 2020.

SANTOS, B. S. A universidade no século XXI: para uma reforma democrática e emancipatória da universidade. São Paulo: Cortez, 2004.

SAVIANI, D. História das ideias pedagógicas no Brasil: Campinas: Autores Associados, 2007.

SGUISSARD, V. Universidade brasileira no século XX. São Paulo: Cortez, 2009.

SOUZA, M. B.; ORTIZ, H. C. A estrutura básica para o ensino superior de contabilidade. São Paulo: Saraiva, 2006. 
TCHEOU, H. Avaliação do ensino de Contabilidade nos Cursos de Administração de Empresas na cidade de São Paulo. Dissertação (Mestrado). Centro Universitário Álvares Penteado, São Paulo, 2002.

VYGOTSKY, L. S., LURIA, A. R. LEONTIEV, A. N. Linguagem, desenvolvimento e aprendizagem. São Paulo: Ícone, 1992. 


\section{EUTANÁSIA: UMA MORTE DIGNA}

\section{EUTHANASIA: A DIGINE DEATH}

FABENI, Pricila ${ }^{1}$

MATOS, Elzira²

\section{Resumo}

Objetivos: O presente estudo tem por objetivo realizar uma análise teórica acerca do direito a uma morte digna, fundamenta-se no princípio da dignidade da pessoa humana e na ética no final da vida. Serão apresentados alguns conceitos e procedimentos muito importantes para o entendimento do tema, entre eles, eutanásia, distanásia, suicídio assistido e ortotanásia, além da autonomia de vontade que se deve levar em consideração aos pacientes que se encontram em estágio terminal. Método: A metodologia utilizada neste artigo é de pesquisa qualitativa e bibliográfica sobre o tema em questão. Resultados: A morte com dignidade nos casos de pacientes em estados terminais é um assunto que merece mais atenção, visto que, em algumas situações não há mais o que se fazer, pois se sabe que o paciente não irá sobreviver. Importante ressaltar que aquela pessoa que esteja em plena sanidade mental e tenha tomado à decisão a respeito de sua morte de maneira livre e responsável, deve ter sua vontade (desejo) levada em consideração, pois estando naquelas situações desconfortáveis (terminais), além do sofrimento, da angustia, também afeta sua moral. Conclusão: $O$ assunto sobre a eutanásia é muito antigo e a população tem certo temor de dialogar claramente sobre a morte, pois para algumas pessoas é o ponto final em si mesmo. Assim, deixam o assunto sobre o tema por demais ignorado. Mas o Estado deve através de casos concreto com pacientes terminais, analisar e deixarem o paciente ou a família optarem pela morte, uma decisão que não deveria ser vista como um desrespeito a Constituição.

Palavras-chave: Dignidade. Direito. Morte.

\section{Abstract}

Objectives: The present study aims to conduct a theoretical analysis about the right to a dignified death, based on the principle of human dignity and ethics at the end of life. Some very important concepts and procedures for understanding the topic will be presented, including euthanasia, dysthanasia, assisted suicide and orthothanasia, in addition to the autonomy of will that must be taken into consideration for patients who are in the terminal stage. Method: The methodology used in this article is for qualitative and bibliographic research on the topic in question. Results: Death with dignity in cases of terminally ill patients is a subject that deserves more attention, since in some situations there is more-to do, as it is known that the patient will not survive. It is important to emphasize that that person who is in full mental health and has made the decision regarding his death in a free and responsible manner, must have his will (desire) taken into account, as he is in those uncomfortable (terminal) situations, in addition to suffering, of anguish, also affects their morale. Conclusion: The subject of euthanasia is a very old one and the population is afraid

\footnotetext{
${ }^{1}$ Acadêmicas do $3^{\circ}$ semestre do Curso de Bacharelado em Direito da Universidade Estadual de Mato GrossoCampus Pontes e Lacerda. E-mail:prifabeni2@gmail.com

2 Professora Mestre da Universidade Estadual de Mato Grosso-Campus Pontes e Lacerda. Email:elziramatos@hotmail.com
} 
to talk clearly about death, because for some people it is the end point in itself. Thus, they leave the subject on the subject too ignored. But the State must, through concrete cases with terminally ill patients, analyze and let the patient or family choose to die, a decision that should not be seen as disrespecting the Constitution.

Keywords: Dignity. Right. Death.

\section{Introdução}

A morte ainda hoje é vista como um tabu, mesmo sabendo que ela é certa para todos, o que não se sabe é o momento exato que irá acontecer. Com o desenvolvimento da medicina permitiu-se a cura de várias doenças e o prolongamento da vida. No entanto, esse avanço está caminhando para um impasse, quando se trata de buscar a cura e salvar uma vida a qualquer custo na qual a morte é inevitável. Um dos maiores temores do ser humano é ter sua vida mantida a qualquer custo mesmo que seja à base de muito sofrimento, tendo como companhia apenas equipamentos de uma UTI, ou talvez nem isso, pois os hospitais nem sempre podem dar essa assistência.

Neste trabalho será abordado os conceitos de eutanásia, distanásia, ortotanásia, suicídio assistido, dentre outros, que se faz necessário para entender e saber se o Brasil aceita tais procedimentos de interrupção contra a vida, principalmente tratando-se de pacientes em estado terminais. Pode-se parar e refletir, até quando a vida deve ser prolongada, será que da mesma maneira que existe o direito a uma vida digna, não deveria haver também o direito a morte uma digna, e a quem caberia tal decisão?

O desenvolvimento científico e tecnológico nos últimos anos prolongou os limites da vida e alterou a face da morte, que refletirá, impreterivelmente, na dogmática jurídico-penal. No Brasil, no momento atual, não há juridicamente nada específico sobre a eutanásia no Código Penal. A intervenção jurídica da cessação da vida é um dos pontos mais complexos e atuais do direito penal.

Deste modo, há uma urgente necessidade de que se organize uma análise atual e humanizada sobre a eutanásia, levando em consideração o indispensável e contínuo consenso entre a bioética, os fundamentos constitucionais e o direito penal. Ainda no Brasil, existe deficiência de estudos mais detalhados sobre a eutanásia na área criminal. A metodologia utilizada neste artigo é de pesquisa qualitativa e bibliográfica sobre o tema em questão. 


\section{Fundamentação Teórica}

O direito à vida estabelece o primeiro direito de qualquer indivíduo, assim, sendo tutelado em atos internacionais, na Constituição e também no direito infraconstitucional. Com o final da segunda guerra mundial, a dignidade da pessoa humana se tornou um dos maiores acordos éticos do mundo. Enquanto que no mundo moderno a dignidade da pessoa humana era o centro axiológico dos sistemas jurídicos.

A dignidade como autonomia, como poder individual é a compreensão que está submetida aos grandes documentos de Direitos Humanos do século XX. Ela envolve a capacidade de autodeterminação, bem como o direito de decidir os nortes da própria vida e de desenvolver espontaneamente a própria personalidade. A autonomia individual permite que o sujeito faça escolhas morais relevantes, tomando para si as responsabilidades sobre suas decisões que foram adotadas.

A dignidade da pessoa humana e a autonomia individual no final da vida é um tema muito complexo, e que ao ser discutido causa opiniões divergentes. A dignidade da pessoa humana pode ser entendida como algo intrínseco a todo e qualquer ser humano, é um elemento indisponível e não pode ser renunciado ou alienado. É um princípio que nunca terá um conceito concreto e limitado, pois cada indivíduo é diferente do outro, cada qual com suas características e valores. A pessoa que ocasionar qualquer atentado contra a dignidade da pessoa humana deverá ser punido pelo sistema penal. Cabe ressaltar que assim como a dignidade da pessoa humana, a bioética e o biodireito também são dois institutos importantes que estão relacionados ao ser humano.

A Bioética nasce como um ramo do conhecimento, cuja finalidade é analisarmos efeitos éticos que o desenvolvimento científico favorece, auxiliando as pessoas a refletirem nas possíveis consequências dos avanços da ciência sobre a vida humana. E para a autora Fernanda Schaefer,

(...) a Bioética designa os problemas éticos gerados pelos avanços das ciências tecnológicas, biológicas e médicas", já o Biodireito seria, portanto, a positivação jurídica de permissões de comportamentos médico-científicos, e de sanções pelo descumprimento destas normas (SCHAEFER, 2007, p. 33).

É muito importante refletir sobre a bioética e também sobre o Biodireito, pois, deste modo, os conflitos e decisões que estão vinculadas a medicina serão resolvidos de uma forma que não haja abusos e que os princípios também não sejam violados. Tanto a bioética quando o Biodireito não pode estar concordando com fatos que podem prejudicar o direito 
pertencente às pessoas. Portanto é de grande valia pensar sobre a bioética, pois assim, os profissionais da área podem exercer sua função de maneira correta, profissional e também humana, deste modo, não havendo o uso do ser humano para outras intenções.

É por meio da Bioética e do Biodireito que se pode debater, questionar temas relacionados à eutanásia, ortotanásia, dentre outros. Além do mais, é muito discutido em qual circunstância pode ser feito a eutanásia e a ortotanásia e se haverá punição para quem cometer determinado procedimento.

Com o avanço da medicina e da tecnologia existem, inclusive, alguns questionamentos sobre a imortalidade do ser humano. Para a sociedade ainda é muito difícil discutir a respeito da morte, pois ninguém pensa em morrer, mas em viver, ter uma vida digna.

A Constituição traz em seu art. $5^{\circ}$, direitos que são inerentes ao indivíduo, direitos estes que visam à dignidade da pessoa. Além do direito à vida, temos o direito à liberdade, à igualdade, à segurança e à propriedade.

Sabe-se que sem o direito à vida, o ser humano não teria outros direitos, então se pode dizer que este direito é o principal para o ser humano. Porém, não podemos deixar de lado o direito à dignidade, ainda mais se tratando de casos em que os pacientes estão em situações graves, isto é, em estado terminal. Muitas vezes os pacientes estão há tempos em hospitais, e não há melhoria para sua situação, ficam sofrendo com tratamentos, medicamentos e assim perdem alegria de viver. Ao perder o desejo pela vida, não sentem ter uma vida digna e morrer com dignidade torna-se mais importante que sua vida.

A eutanásia, também conhecida como boa morte acontece quando o paciente sabe que a sua doença não tem cura ou assume tal situação que o levará a não ter condições mínimas de ter vida digna, então pede ao médico ou a terceiro que lhe tire a vida antecipadamente, desta forma, evitando sofrimentos, dores físicas e psicológicas.

\footnotetext{
Entende-se como eutanásia a conduta em que alguém, deliberadamente é movido por fortes razões de ordem moral, causa a morte de outrem, vítima de uma doença incurável em avançado estado e que está parecendo de grande sofrimento e dores. A eutanásia seria justificada como uma forma de libertação do sofrimento acarretado por um longo período de doença (MARTINS, 2010, p. 21).
}

No Brasil, a eutanásia é crime, é ilegal e também é considerada antiética pelo código de medicina, porém existe a ortotanásia que é aceita em nosso país. Segundo a médica Rachel Duarte Moritz, a ortotanásia seria deixar morrer, enquanto a eutanásia seria fazer morrer, ou seja, a morte ocorreria aos poucos, naturalmente, enquanto que a eutanásia seria uma morte tida ou vista como rápida, que ocorreria através de medicamentos injetados ao paciente, ou através do desligamento de aparelhos médicos. O artigo a morte como ela é: dignidade $e$ RCMOS - Revista Científica Multidisciplinar O Saber. ISSN: 2675-9128. São Paulo, v. 02, n. 2, p. 01-10, fev. 2021. 
autonomia individual no final da vida, dos autores Luís Roberto Barroso e Letícia de Campos

Velho Martel, pontuam que a ortotanásia,

Trata-se da morte em seu tempo adequado, não combatida com os métodos extraordinários e desproporcionais utilizados na distanásia, nem apressada por ação intencional externa, como na eutanásia. É uma aceitação da morte, pois permite que ela siga seu curso. É prática "sensível ao processo de humanização da morte, ao alívio das dores e não incorre em prolongamentos abusivos com aplicação de meios desproporcionados que imporiam sofrimentos adicionais" (BARROSO; MARTEL, 2010, p. 5).

Assim, entendemos que a ortotanásia é a possibilidade de suspender os meios artificiais que submetem o paciente em estado terminal a procedimentos agressivos, que irão prolongar a sua vida quando esta não é mais possível, diante as condições (irreversíveis) em que se encontra. A ortotanásia também é chamada de morte digna, ou seja, ela é uma morte natural com todos os auxílios médicos adequados, mediante uma intervenção plena no sofrimento humano.

Também existem os procedimentos de suicídio assistido e distanásia. No suicídio assistido ocorre a método na qual o próprio paciente retira sua vida, porém há ajuda de terceiros, tais como, os médicos, familiares, amigos, entre outros. O nosso ordenamento jurídico criminaliza o suicídio assistido, deste modo, condenando quem pratica tal procedimento.

Suicídio assistido designa a retirada da própria vida com auxílio ou assistência de terceiros. $\mathrm{O}$ ato causador da morte é de autoria daquele que põe termo à própria vida. $\mathrm{O}$ terceiro colabora com o ato, quer prestando informações, quer colocando à disposição do paciente os meios e condições necessárias à prática. $\mathrm{O}$ auxílio e a assistência diferem do induzimento ao suicídio. No primeiro, a vontade advém do paciente, ao passo que no outro o terceiro age sobre a vontade do sujeito passivo, de modo a interferir com sua liberdade de ação (BARROSO; MARTEL, 2010, p.7).

Enquanto que a distanásia é um procedimento que visa o prolongamento da morte do paciente utilizando-se todos os meios plausíveis, mesmo que não se tenha algum tipo de esperança para cura do paciente.

Por distanásia compreende-se a tentativa de retardar a morte o máximo possível, empregando, para isso, todos os meios médicos disponíveis, ordinários $\mathrm{e}$ extraordinários ao alcance, proporcionais ou não, mesmo que isso signifique causar dores e padecimentos a uma pessoa cuja morte é iminente e inevitável (BARROSO; MARTEL, 2010, p. 4).

A distanásia nada mais é que um prolongamento artificial da vida do paciente, cujo este não tem mais a chance de ser curado e tampouco de recuperar-se de sua saúde de acordo com a ciência de saúde. Na distanásia não é prolongada à vida do paciente, mas sim a sua 
morte. E em determinados casos, em vez de ajudar o paciente ou permitir uma morte natural, acaba adiando seu sofrimento.

A obstinação terapêutica e tratamento fútil estão ligados à distanásia. A primeira versa na conduta médica de combater a morte de todas as maneiras possíveis, é como se o paciente fosse ser curado. $\mathrm{O}$ segundo são as técnicas e procedimentos extraordinários, que não tem capacidade de melhoria ou cura para o enfermo, mas que prolongam a vida, mesmo gerando sofrimento, de tal forma em que os benefícios previsíveis são muito baixos aos danos causados.

E por fim, tem-se o cuidado paliativo que é indissociável da ortotanásia, está relacionado ao uso de toda a tecnologia possível para diminuir o sofrimento físico do paciente, assim, melhorando a qualidade de vida do paciente. E a renúncia do tratamento médico versa na negação de iniciar ou de nutrir um ou alguns tratamentos médicos.

\section{Resultados e discussões}

Essa questão sobre a Eutanásia ou qualquer uma de suas modalidades é algo muito complexo, alguns indivíduos são a favor da eutanásia, distanásia, ortotanásia, suicídio assistido e outros meios para interrupção da vida, sejam em pacientes de estado terminal ou não, e existe a parte contrária contra qualquer tipo de interrupção da vida, pois sustentam que a vida humana é um bem jurídico supremo que não deve ser interrompido por hipótese alguma, e que deve ser tutelado tanto pelo Estado, como pelo médico inclusive pelo próprio titular.

Devemos ressaltar, por fim, que morte com dignidade nos casos de pacientes em estados terminais é um assunto que merece mais atenção, visto que, em algumas situações não há mais o que se fazer, pois se sabe que o paciente não irá sobreviver. Além do mais, deve-se levar em consideração à autonomia individual, pois é através dela que o indivíduo traça planos e os realiza.

Importante ressaltar que aquela pessoa que esteja em plena sanidade mental e tenha tomado à decisão a respeito de sua morte de maneira livre e responsável, deve ter sua vontade (desejo) levada em consideração, pois estando naquelas situações desconfortáveis (terminais), além do sofrimento, da angústia, também afeta sua moral. Aceitar o término da vida é reconhecer a morte como parte incondicional da vida e da existência humana, tão natural e previsível como nascer. 


\section{Considerações finais}

O debate sobre a eutanásia é muito antigo como a vida em sociedade. E da mesma forma é o temor de se dialogar claramente sobre a morte, que para alguns é o ponto final em si mesmo, deixando desta forma, o assunto sobre o tema por demais ignorado.

A realidade é que, com o aperfeiçoamento tecnológico que aconteceu, a pessoa, enquanto enfermo, passou a ser um simples objeto que os médicos praticam sua profissão, o que certamente é uma escolha extremada.

Diante do exposto, compreendeu-se uma considerável modificação no posicionamento médico conforme a visão do tema, sendo de grande importância. Distancia-se o conceito paternalista de que apenas o médico tem o direito de optar pelo prosseguimento da vida ou pelo seu fim, passando a ser conservada a autonomia da vontade do paciente à frente do fato material. A respeito dessa transição, tem pessoas que apoiam argumentando que a vida humana é um bem jurídico supremo e absoluto, cabendo ao Estado, representado pelo profissional médico, protegendo-a a qualquer forma, impedindo o fim da vida da pessoa.

Nesse contexto, os direitos do paciente ficariam várias vezes, submetido aos interesses do Estado, que define o emprego de todas as medidas disponíveis que possa prolongar da vida do paciente, mesmo que seja contra sua vontade, distanciando seja qual for, a possibilidade a respeito da prática da eutanásia.

A pesquisa de base teórica teve como objetivo principal apresentar sustentação que suportasse o respaldo, ao direito daquele que é portador de doença grave, sem expectativa de cura, ou ainda para as pessoas que estão em estado irreversível, para que tenha uma morte digna de acordo com suas crenças e valores.

O caso da pessoa enquanto paciente recusar-se a alguns tratamentos que visam prolongar o seu sofrimento não tem sentido, porque ele estaria desrespeitando a santidade da vida. Seria contraditória, este pessoa, ou sua família, decidir pela eutanásia apenas para evitar sofrimento desnecessário, alegando que a morte é inelutável.

Levando em conta exclusivamente o caráter da inalienabilidade e a inviolabilidade do direito à vida, que é um bem supremo por excelência, certifica a ilicitude da prática da eutanásia, não dispondo ao familiar, ao médico, ou o próprio paciente decidir pela morte, mesmo que seja a sua própria e motivada pela piedade, ou fundamentada na dignidade da pessoa humana. 
Chegar a um conceito selado do que é a vida, não é fácil. Pelo menos se considera uma vida não digna, quando uma pessoa que é paciente se encontra em circunstâncias frequentes do dia a dia, aprisionada ao leito, mantido por aparelhos, inconsciente do que ocorre à sua volta, não conseguindo sozinho executar suas necessidades intimas.

Necessita-se ter muita atenção ao se estudar as influências operadas pelos valores morais, éticos, religiosos e jurídicos quanto à conservação da vida diante situações que não se revertem. Responder a um paciente ou familiar a respeito de suas reclamações de morrer não é fácil, porém mesmo que seja seu direito o argumento ainda é que a vida humana é sagrada, mantendo vivo em qualquer condição que esteja, naquele espaço de tempo que necessitar.

O respeito à vida humana é um ordenado jurídico de ordem constitucional, necessitando, ser vista a dignidade do direito de morrer, afinal a dignidade da pessoa humana não é a possibilidade de conduzir sua vida e realizar sua personalidade conforme sua própria consciência, desde que não atinja direito do próximo.

As legislações estrangeiras vêm analisando regularmente sobre o assunto da eutanásia e para alguns países é visto como um modelo de homicídio privilegiado. Mas, alguns outros países faz uso da prática. O Brasil é extremamente contra a prática, inserindo delito seguido às demais formas de homicídio dentro do Código Penal.

A aceitação da prática da eutanásia acarreta muitos riscos e perigos escondidos em algumas de suas modalidades. A ciência a cerca destes riscos é fundamental para que se trabalhe o tema no meio jurídico.

Porém vale salientar que mesmo o assunto sendo polemico, não distancia a urgência e a necessidade de se discutir o tema de forma explícita. Assim, os juristas possam ter sustento em casos concreto, mudando assim o cenário que temos hoje no Brasil.

O direito a vida e a dignidade a ela são obrigações do Estado, devendo o mesmo assegurar dignidade ao ser humano proporcionar os mecanismos que proíbam seja qual for o ato que afronte a vida, restringindo à autonomia privada, relacionada ao seu direito individual, sustentando no direito à dignidade e a liberdade.

Assim, o tempo é de efetivar ações púbicas apontem à proteção do Estado Democrático de Direito defendendo a vida não somente por obrigação de viver carregando em si todo sofrimento de um tratamento de doença terminal e sim, proteger a vida com enfoque na dignidade da pessoa humana. 


\section{Referências}

BARROSO, L. R.; MARTEL, L. de C. V. A morte como ela é: dignidade e autonomia individual no final da vida. In: Panóptica 19, 69-104, jul.out. 2010. Disponível em: http://www.panoptica.org/seer/index.php/op/article/view/Op_5.2_2010_69-104/293. Acesso em: nov. 2017.

BECCARIA, C. Dos Delitos e das Penas. Tradução J. Cretella Jr. E Agnes Cretella. 5. ed. São Paulo: Editora Revista dos Tribunais, 2011.

FARIAS, E. P. Colisão de direitos: a honra, a intimidade, a vida privada e a imagem versus a liberdade de expressão e informação. 2. ed., atual. Porto Alegre: Sergio Antonio Fabris Editor, 2000.

MARTINEZ, S. R.; BELO S. Z. Os pacientes terminais e o princípio da dignidade da pessoa humana. civilistica.com. a. 4. n. 1. 2015. Disponível em: http://civilistica.com/wpcontent/uploads/2015/08/Martinez-e-Belo-civilistica.com-a.4.n.1.2015.pdf. Acesso em: nov. 2017.

MARTINS, M. S. M. Direito à morte digna: Eutanásia e morte assistida. Âmbito Jurídico, Rio Grande, XIII, n. 83, dez. 2010. Disponível em:

$\mathrm{http}: / /$ www.ambitojuridico.com.br/site/index.php?n_link=revista_artigos_leitura\&artigo_id=8 765. Acesso em: nov. 2017.

MORAES, A.de. Direito Constitucional. 25. ed. São Paulo: Atlas, 2010.

NOGUEIRA, P. L. Em defesa da vida: aborto, eutanásia, pena de morte, suicídio, violência/linchamento. São Paulo: Saraiva, 1995.

REALE, M. O Direito como experiência: introdução à epistemologia jurídica. 2. ed. São Paulo: Saraiva, 1992.

ROXIN, C. Estudos de Direito Penal. Tradução de Luís Greco. 2. ed. Rio de Janeiro: Renovar, 2008.

SCHAEFER, F. Bioética, Biodireito e Direitos Humanos. In: MEIRELLES, J. M. L. de. (Coord.). Biodireito em discussão. Curitiba: Juruá, 2007, p. 33. Acesso em: dez. 2017.

VILLELA, J. B. Variações impopulares sobre a dignidade da pessoa humana. Superior Tribunal de Justiça: doutrina. Edição comemorativa. São Paulo, 2009

TARTUCE, F. A questão do testamento vital ou biológico - primeiras reflexões. In: CARVALHO NETO, I. de (coord.). Novos direitos após seis anos de vigência do código civil de 2002. Curitiba: Juruá, 2009

ZAFFARONI, R.E.; BATISTA, N. Direito Penal brasileiro. Teoria do delito: introdução histórica e metodológica, ação e tipicidade. v. 2, 2. ed. Rio de Janeiro: Revan, 2010. 


\title{
PROPAGANDA MÉDICA NAS REDES SOCIAIS: UMA REALIDADE POSSÍVEL
}

\section{MEDICAL PROPAGANDA: A POSSIBLE REALITY}

\author{
FAVACHO, Natasha Costa ${ }^{1}$
}

\section{Resumo}

Objetivos: Este estudo avalia, primeiramente, a distinção entre os termos publicidade e propaganda e sua aplicação à atividade médica, justificando a escolha do termo "propaganda" no título deste artigo. Em um segundo momento, a pesquisa aborda o arcabouço normativo que permite aos Conselhos Federal e Regionais de Medicina regulamentar os limites e restições à propaganda pelos médicos e adotar as providências e sanções cabíveis no caso de violação às normas legais e éticas nas relações médico-paciente. Posteriormente, analisam-se os diplomas normativos e deontológicos, suas respectivas permissões e proibições de condutas do profissional médico ao realizar propaganda nas redes sociais. Finalmente, delineam-se as práticas de utilização das redes sociais pelos médicos em conformidade com a ética médica e com a Lei, chegando-se à conclusão de que é plenamente possível a realização de propaganda pelos médicos nas mídias sociais, desde que obedecidos os parâmentros legais e deontológicos da profissão. Metodologia: O presente artigo analisa a possibilidade de os profissionais da Medicina utilizarem ferramentas de propaganda nas redes sociais, mediante pesquisa bibliográfica de textos contidos em obras sobre Direito Médico e análise legistativa de normas legais e deontológicas que regem a atividade médica no Brasil. Os indicadores boleanos utilizados para pesquisa dos títulos foram "and" e "or", a partir dos seguintes descritores: "Propaganda", "Publicidade" e "Redes Sociais" e "Relação Médico-Paciente", todos extraídos do DeSC.

Palavras-chave: Propaganda. Publicidade. Redes Sociais. Relação Médico-Paciente.

\section{Abstract}

Objectives: This study evaluates, firstly, the distinction between the terms advertising and propaganda and its application to medical activity, justifying the choice of the term "propaganda" in the title of this article. In a second moment, the research approaches the normative framework that allows the Federal and Regional Medical Councils to regulate the limits and restitions to advertisement by doctor and to adopt the appropriate measures and sanctions in case of violation of legal and ethical norms in doctor-patient relations. Afterwards, the normative and deontological diplomas, their respective permissions and prohibitions of conduct of the medical professional when advertising on social networks are analyzed. Finally, the practices of use of social networks by doctors are outlined in accordance with medical ethics and the law, reaching the conclusion that it is fully possible for doctors to advertise on social media, provided that the legal and deontological parameters of the profession are followed. Methods: This article analyzes the possibility of medical professionals to use advertising tools in social networks, through bibliographic research of texts contained in works on Medical Law

\footnotetext{
${ }^{1}$ Pós-graduada em Direito de Família pela Universidade Estácio. Bacharel em Direito pela Universidade Federal do Pará. Ex-advogada. Servidora Pública Efetiva do Tribunal de Justiça do Estado do Pará. Foi Diretora de Secretaria da $7^{\mathrm{a}}$ Vara de Família de Belém. Analista Judiciária. Endereço eletrônico: natashafavacho86@gmail.com.
} 
and legal analysis about the legal and deontological norms that govern medical activity in Brazil. The Boolean indicators used for research of the titles were "and" and "or", from the following descriptors: "Propaganda", "Advertising" and "Social Networking" and "PhysicianPatient Relations", all extracted from DeSC.

Keywords: Propaganda. Advertising. Social Networking. Physician-Patient Relations.

\section{Introdução}

A era digital modificou completamente os paradigmas de comunicação em sociedade e os padrões de propaganda e publicidade apresentados ao público. O crescimento da rede mundial de computadores (internet), com o escopo de conectar os indivíduos, compartilhar informações, fotos, vídeos e conhecimento, fez surgir redes sociais como Facebook, Instagram, YouTube e aplicativos de comunicação instantânea como Whatsapp e Telegram, atingindo o cotidiano social de forma impactante, fazendo com que as pessoas experimentem um grande dinamismo na propagação e troca de informações, potencializando, deste modo, as capacidades comunicativas dos indivíduos nas mais variadas esferas sociais.

O Brasil conta com, aproximadamente, 212 milhões de habitantes e, segundo pesquisa "Digital in 2020"2, no mês de janeiro de 2020, haviam 205,8 milhões de conexões móveis no País e 140 milhões de pessoas utilizando alguma rede social.

Daí, observa-se que com o acesso de grande parte da população à internet, através de dispositivos móveis como tablets e smartphones, as redes sociais passaram a ter um papel fundamental no cotidiano das pessoas e, a rede mundial de computadores, especialmente em tempos de pandemia de Sars-coV-2 (coronavírus) que assola o planeta há mais de um ano, passou a ser uma grande vitrine de diversos profissionais dos mais variados ramos. Assim, a publicidade e propaganda on-line demonstram deter o potencial de alcançar o público com muito mais intensidade do que a tradicional, veiculada pela televisão, por cartazes, folhetos, outdoors, etc.

Os meios de comunicação atuais são distintos dos utilizados pelas sociedades anteriores. Como dito linhas acima, atualmente, o processo de informação tornou-se mais participativo, principalmente com a produção de conteúdo de forma instantânea, que não apenas entrega as informações, como também coleta do usuário as tendências e pensamentos do momento. Além disso, o fornecimento desses materiais, ideias, vídeos e fotos mediante as redes sociais permite uma interação entre quem os produz e quem os recebe, facilitando a comunicação em tempo real desses sujeitos e o aprofundamento desse relacionamento virtual. Com a utilização em

\footnotetext{
${ }^{2}$ We are social. Digital 2020: global digital yearbook. Disponível em: https://datareportal.com/reports/digital2020-brazil. Acesso em: 22 jan. 2021.
} 
massa das redes sociais, vivencia-se o surgimento de novas tecnologias, o aparecimento de novas profissões e o desaparecimento de inúmeras outras. As que sobrevivem precisam adaptar os novos conceitos, as novas tendências, métodos e mídias para manter sua continuidade. Com a Medicina não está sendo diferente.

Os profissionais da saúde, enquanto prestadores de serviços relativos à Medicina e à saúde, aderiram ao marketing e à propaganda, também referida como publicidade, no meio digital, em especial nas redes sociais, graças a maior oportunidade de se conectarem com seus pacientes e potenciais pacientes, mantendo-os informados sobre os seus serviços (MILDEMBERGER; PEREIRA, 2020, p. 399).

Diante disso, a busca por estar nas redes sociais trouxe uma temática que vem acompanhando os médicos: a propaganda nas estruturas online na qual diversas pessoas estão conectadas umas às outras, partilhando ideias, objetivos, pensamentos e valores em comum, seja para divulgar novas práticas ou métodos de tratamentos, seja para informar e educar os pacientes sobre determinado assunto.

Ocorre que, nesse contexto, surge o grande desafio para os profissionais da saúde, qual seja: fazer propaganda nas redes sociais de maneira a manterem-se competitivos no mercado de trabalho e, ao mesmo tempo, agir de forma ética e legal, respeitando os direitos de seus pacientes e obedecendo às normas legais e deontológicas em vigor, as quais regem sua profissão, pois a Medicina, como será explanado ao longo dessa pesquisa, em nenhuma circunstância, pode ser ser exercida como comércio.

A presente pesquisa se deu mediante a análise bibliográfica de textos contidos em obras sobre Direito Médico e por meio da interpretação da normatização legal e deontológica que rege a atividade médica no Brasil, em razão da novidade do tema.

A metodologia utilizada para este artigo consiste em uma pesquisa bibliográfica e legislativa baseada em diferentes fontes de dados como livros impressos, Resoluções do Conselho Federal de Medicina e publicações na internet.

A pesquisa é de caráter exploratório, no sentido de se interpretar, no contexto da evolução tecnológica pelo qual passa a sociedade, a possibilidade de o profissional médico utilizar as redes sociais para fazer propagada, com base nas normas que regem a profissão, bem como analisar o papel dos Conselhos de Medicina quanto à fiscalização e normatização das condutas dos médicos quando realizam propagandas nas redes sociais e traçar os limites éticos e legais para a propaganda médica nessas estruturas online. Sendo assim, esse artigo pretendeu promover a discussão de um tema de grande relevância para o aprimoramento do Direito 
Médico na atualidade e nos âmbitos profissionais e acadêmicos, analisando e explanando a possibilidade de realização da propaganda pelos profissionais médicos nas redes sociais, desde que feita em estrita obediência e respeito à Constituição Federal de 1988, à Lei e às Resoluções do Conselho Federal de Medicina e normas dos Conselhos Regionais de Medicina.

O debate é necessário para que haja a ampliação dos estudos sobre os limites da propaganda médica nas redes sociais à luz da evolução do comportamento da sociedade e das normas legais e deontológicas sobre a profissão médica, eis que o tema é novo, servindo de norte e orientação para a conduta de profissionais médicos frente às novas tecnologias que permitem a propagação de informações e a realização de comunicação através da rede mundial de computadores e de operadores do Direito na defesa e na prestação de consultoria para profissionais médicos, seja na esfera administrativa, perante os Conselhos Regionais e Federal de Medicina, seja na esfera judicial.

\section{REFERENCIAL TEÓRICO}

\subsection{Distinção entre os conceitos de publicidade e propaganda}

A relação médico-paciente é peculiar, pois, apesar do aspecto patrimonial advindo do pagamento pelo serviço prestado pelo profissional ao paciente, também há a necessidade de respeito e obediência a diversos direitos e deveres relativos a valores sociais que integram tal relação, como o direito à informação prestada pelo médico ao paciente sobre seu estado de saúde, a terapêutica a ser utilizada, de recusa de tratamento por aquele, dever de sigilo, dever de obtenção pelo profissional do consentimento livre e esclarecido pelo paciente, direito de exercício da atividade médica com liberdade e autonomia, dentre outros.

Mesmo que não possuam uma expressão ecônomica direta, mencionados direitos e deverem estão intimamente vinculados à dignidade da pessoa humana e à personalidade do indivíduo, pois, como disse a Ministra Carmen Lúcia do Supremo Tribunal Federal, saúde não é mercadoria, vida não é negócio, dignidade não é lucro (STF, 2021).

Nesse contexto, embora haja o entendimento de que a relação entre médico e paciente seja uma relação de consumo, não sendo essa discussão objeto do presente artigo, nessa pesquisa, adota-se a compreensão de que dita relação não pode ser consumeirizada, eis que jamais a Medicina pode ser exercida como atividade mercantil, sendo vedado ao médico o exercício mercantilista de sua profissão (CFM, 2019). Dessa maneira, considerando que a 
atividade médica não é comércio, faz-se necessário distinguir os conceitos de publicidade e propaganda, de modo a aplicar corretamente os termos à atividade médica e justificar a utilização da concepção propaganda no título desta pesquisa.

Pois bem, muitas vezes, os termos publicidade e propaganda médica são utilizados como sinônimos, inclusive pelo Conselho Federal de Medicina, o qual define, na Resolução $\mathrm{n}^{\mathrm{o}}$ 1.974/2011, em seu artigo $1^{\circ}$, anúncio, publicidade ou propaganda como a comunicação ao público, por qualquer meio de divulgação, de atividade profissional de iniciativa, participação e/ou anuência do médico (CFM, 2011).

Referidos termos são usualmente utilizados para definir a prática de difusão de textos, anúncios, etc., os quais têm como objetivo influenciar os indivíduos a consumir determinado produto ou serviço ou a aderir a certo pensamento, ideia ou religião, por exemplo. Todavia, há distinções que merecem ser pontuadas para que se use adequadamente os conceitos em questão.

A publicidade pode ser definida como a comunicação realizada por uma empresa para promover objetos, artefatos, serviços e ideias, de modo a persuadir um público a desejar comprar seus produtos. Tem por objetivo atrair o consumidor com a esperança de venda ou contrato de bens e serviços. Essa concepção, portanto, atinge uma esfera comercial e consiste em uma ferramenta a serviço do mercador ou fornecedor de serviço.

Desta forma, a publicidade é o ato de tornar público, divulgar um fato ou uma ideia com objetivos comerciais, já que busca despertar o desejo de compra e aquisição de determinado produto ou serviço, promovendo, desta forma, uma atividade comercial (GONÇALEZ, 2009, p. 7).

A propaganda, por sua vez, é a comunicação utilizada por organizações ou pessoas para disseminar pensamentos e doutrinas, geralmente religiosas, ideológicas ou políticas. Busca adesão a uma ideologia ou mudança de atitude do público em relação a determinada pessoa ou determinado assunto. A esfera é política, ideológica ou religiosa. Consiste na veiculação de anúncio ou mensagem persuasiva em meio de comunicação, tem caráter de esclarecimento e informação da sociedade. Abrange ações de atividades ideológicas que tendem a influenciar o homem com objetivo político, cívico ou religioso (GONÇALEZ, 2009, p. 7). É o ato de propagar ideias, princípio e teorias sem o viés mercantil ou econômico. Ora, como é possível constatar, publicidade está relacionada às atividades comerciais e mercantis enquanto a propaganda refere-se à propagação de informações, ideias, pesamentos, sem caráter comercial, sendo este último, por conseguinte, o termo mais adequado a ser utilizado na atividade médica, motivo pelo qual foi escolhida a expressão propaganda como componente do título do presente 
artigo. Vale, contudo, alertar o leitor, que, embora existam as diferenças apontadas entre os conceitos ora elencados, a expressão publicidade é utilizada (como sinônimo de propaganda) nos diplomas normativos dos Conselhos de Medicina analisados ao longo desta pesquisa. Ultrapassadas essas distinções, passa-se à análise do arcabouço legal que rege o tema.

\subsection{Da legitimidade e legalidade de regulamentação da medicina pelos conselhos profissionais}

Nos tempos modernos, a Medicina continua a ser uma profissão liberal, todavia, para que sua prática seja realizada nos parâmetros legais, há restrições que, em momentos anteriores da história, não existiam.

Independentemente do vínculo do médico, seja ele assalariado, autônomo ou servidor público, ele é considerado como profissional liberal e, mesmo que a profissão possa estar sujeita aos moldes socieconômicos vigentes, a Medicina, na condição de profissão liberal, tem como característica a liberdade do exercício de suas atividades na mais ampla autonomia e dentro de uma compatibilidade com a ordem pública e social. Tal liberdade, é evidente, está em tudo aquilo que essa ordem admite como lícito e necessário.

Nas sociedades atuais, a deontologia médica obedece às normas legais, infralegais e códigos de ética profissional, como parâmetros mínimos de conduta impostos pelo Estado com o escopo de garantir o exercício da profissão dentro de certos limites. A Medicina, principalmente nos útlimos trinta anos, sofreu um extraordinário e vertiginoso progresso, o que obrigou os profissionais médicos a enfrentar novas situações, muitas delas em sensível conflito com sua formação e com o passado Hipocrático, no qual o médico era tido como superior na relação médico-paciente, sendo sua vontande soberana e suas indicações deveriam ser cumpridas à risca, sem a interferência do paciente. Havia um certo "paternalismo" do médico em relação ao paciente.

Nesta senda, verifica-se que o médico sempre teve como guias sua consciência e uma tradição milenar, porém, dia a dia, surge a necessidade de conciliar esse pensamento e o interesse profissional com as mútiplas exigências da coletividade, as quais estão em constante modificação (LESSA, 2020, p. 17).

O homem se viu obrigado, em toda a história da humanidade, a viver socialmente e essa vida em comum exige formas de conduta que orientem o caminho do bem. Na medida em que a Medicina avança em suas conquistas e investigações, maior se torna o risco desse 
desenvolvimento. Longe de se diluir ou atenuar a significação da Ética, faz-se ela doravante mais mister do que nunca (FRANÇA, 2021).

Para Genival Veloso França, presume-se que a partir da metade do século passado a profissão médica começou a perder os vínculos com a ética clássica e seu "paternalismo" (superioridade de juízo) foi perdendo força, pois seu domínio de ação cedia espaço para outras profissões da área da saúde e na década de 1980 do século passado, foi-se vendo que a relação médico-paciente-sociedade deveria se fazer através de princípios, devendo cada caso ser tratado de forma própria (FRANÇA, 2021).

Desta forma, constata-se que a ética médica contemporânea vem se ajustando paulatinamente aos anseios da sociedade, pois, assim como outras profissões e áreas do conhecimento, a Medicina vem experimentando um ritmo vertiginoso de crescimento de inovações tecnológicas e as prioridades, novidades e mercantilização terapêuticas criam uma Medicina que evolui para uma sustentação cada vez mais difícil, sobretudo em um contexto no qual se verifica um grave quadro de desigualdades sociais, em particular, no que diz respeito ao acesso às inovações tecnológicas nesse campo por parte da maioria da população, que ainda fica alijada em determinadas situações (HOLANDA; MATOS, 2021).

Sendo assim, ao ser realizada a análise da ética no âmbito da saúde, busca-se diminuir a distância entre ela e o conhecimento e as formas de propagação deste e de várias fontes de informação frente às inovações tecnológicas que surgem diariamente na sociedade moderna.

Os métodos, procedimentos e orientações utilizados no passado acabam por não trazer uma segurança efetiva na tomada de decisões pelos profissionais, porque as condutas morais e a responsabilização do médico em relação aos seus pacientes também experimentam constante evolução e modificação na sociedade. Assim, a Medicina, enquanto ciência, necessita de desenvolvimento técnico e de um instrumento norteador de seus comportamentos, o qual é expresso mediante a deontologia médica.

Nesse cenário, a profissão médica experimenta uma regulamentação em dispositivos legais e infralegais, com o escopo de garantir o exercício da Medicina dentro de parâmetros mínimos, já que, na atualidade, os médicos enfrentam novas situações, utilizam tecnologias que não existiam antigamente, como é o caso das redes sociais, cada vez mais presentes no cotidiano dos indivíduos, e precisam balizar suas condutas de modo a zelar pelo perfeito desempenho ético da Medicina, bem como pelo prestígio e bom conceito da profisssão. A partir deste momento, considerando que houve a necessidade de criação de normas para balizar o comportamento do profissional da medicina de acordo com orientações morais, éticas e 
jurídicas nas suas relações com pacientes, com a sociedade e com seus colegas de trabalho, serão analisados os normativos que regem a profissão médica. Em primeiro lugar, cabe aqui destacar que o artigo $5^{\circ}$, inciso XIII, da Constituição Federal de 1988 garante o livre exercício de qualquer profissão, desde que atendidas às exigências legais, consoante transcrição a seguir:

\begin{abstract}
Art. $5^{\circ}$ Todos são iguais perante a Lei, sem distinção de qualquer natureza, garantindo-se aos brasileiros e aos estrangeiros residentes no País a inviolabilidade do direito à vida, à liberdade, à igualdade, à segurança e à propriedade, nos termos seguintes:

XIII - é livre o exercício de qualquer trabalho, ofício ou profissão, atendidas as qualificações profissionais que a Lei estabelecer;
\end{abstract}

Com efeito, o exercício das profissões é livre, porém, essa liberdade deve ser interpretada nos limites da Lei federal, nos termos do artigo 22, inciso XVI, da Carta Magna, in verbis:

Art. 22. Compete privativamente à União legislar sobre:

XVI - organização do sistema nacional de emprego e condições para o exercício de profissões.

Da análise dos dispositivos contitucionais acima colacionados, verifica-se que os médicos submetem-se à regulamentação constitucional, bem como à legal e infralegal no exercício de sua profissão, ou seja, para que possam exercer livremente suas atividades, devem obediência às referidas normas.

O decreto $\mathrm{n}^{\circ} 20.931 / 1932$, em vigor até os dias atuais, é umas das primeiras normas aplicáveis aos médicos. Ele regula e fiscaliza o exercício da Medicina, da odontologia, da medicina veterinária e das profissões de farmacêutico, parteira e enfermeira no Brasil.

Referido decreto disciplinou, em seus artigos $1^{\circ}$ e $2^{\circ}$, que exercício da Medicina, da odontologia, da medicina veterinária e das profissões de farmacêutico, parteira e enfermeiro, ficava sujeito à fiscalização na forma nele estabelecida, apenas sendo permitido o exercício das profissões ora enumeradas, em qualquer ponto do território nacional, a quem se achar habilitado nelas de acordo com as leis federais e tiver título registrado na forma do art. $5^{\circ}$ de mencionada norma.

Em época mais recente, foi publicada a Lei $\mathrm{n}^{\circ} 12.842 / 2013$, que versa sobre o exercício da Medicina e, em seu artigo $2^{\circ}$ dispõe que o objeto da atuação do médico é a saúde do ser humano e das coletividades humanas, em benefício da qual deverá agir com o máximo de zelo, com o melhor de sua capacidade profissional e sem discriminação de qualquer natureza. Por sua vez, a Lei nº 3.268/1957 foi o diploma legal que criou os Conselhos de Medicina, que são autarquias, motivo pelo qual são dotados de personalidade jurídica de direito público, com autonomia financeira e administrativa e, em seu artigo $2^{\circ}$, previu que os Conselhos Regionais 
de Medicina são órgãos fiscalizadores e aplicadores de sanções, além de serem os responsáveis pela verificação do desempenho ético da Medicina. Confira-se:

Art . $2^{\circ} \mathrm{O}$ conselho Federal e os Conselhos Regionais de Medicina são os órgãos supervisores da ética profissional em tôda a República e ao mesmo tempo, julgadores e disciplinadores da classe médica, cabendo-lhes zelar e trabalhar por todos os meios ao seu alcance, pelo perfeito desempenho ético da medicina e pelo prestígio e bom conceito da profissão e dos que a exerçam legalmente.

$\mathrm{O}$ artigo $5^{\circ}$, alínea $d$, de mencionada Lei, ainda confere ao Conselho Federal de Medicina a possibilidade de votar e alterar o código de deontologia médica, ouvidos os Conselhos Regionais de Medicina, garantindo, desta forma, a plena capacidade às autarquias de regulamentar a atividade médica.

Ademais, o artigo 20 da Lei acima referenciada ainda dispõe que Todo aquele que mediante anúncios, placas, cartões ou outros meios quaisquer se propuser ao exercício da medicina, em qualquer dos ramos ou especialidades, fica sujeito às penalidades aplicáveis ao exercício ilegal da profissão, se não estiver devidamente registrado.

Da análise desses dispositivos legais, fácil constatar que a Lei conferiu ao Conselho Federal de Medicina e aos Conselhos Regionais de Medicina a faculdade de estabelecer normas que regulam as condutas médicas, através de resoluções, as quais configuram um dos meios de dar efetividade às leis, fazendo também parte do processo legislativo, consoante disposição do artigo 59, inciso VII da Carta Maior de 1988.

Ademais, os Conselhos Federal e Regionais de Medicina, quando editam normas, aplicam sanções e efetuam as diligências necessárias, nada mais são do que a própria Administração Pública atuando na sociedade, já que, como dito linhas acima, são autarquias criadas por Lei, as quais exercem e titularizam atividades típicas da Administração, nos termos do artigo 37, inciso XIX, da Constituição Federal de 1988, in verbis:

Art. 37. A administração pública direta e indireta de qualquer dos Poderes da União, dos Estados, do Distrito Federal e dos Municípios obedecerá aos princípios de legalidade, impessoalidade, moralidade, publicidade e eficiência e, também, ao seguinte:

XIX - somente por Lei específica poderá ser criada autarquia e autorizada a instituição de empresa pública, de sociedade de economia mista e de fundação, cabendo à Lei complementar, neste último caso, definir as áreas de sua atuação (Redação dada pela Emenda Constitucional nº 19, de 1998).

Além disso, a Lei $n^{0} 3.268 / 1957$, em seu artigo 15 e alíneas, também confere aos Conselhos Regionais de Medicina as atribuições de fiscalizar o exercício da profissão de médico, conhecer, apreciar e decidir assuntos atinentes à ética profissional, impondo as 
penalidades adequadas, bem como promover, por todos os meios e o seu alcance, o perfeito desempenho técnico e moral da Medicina e o prestígio e bom conceito desta, da profissão e daqueles que a pratiquem, também exercer os atos de juridição que por Lei lhes sejam cometidos.

Logo, restou evidente que, no exercício do poder regulamentar, cabe ao Conselho Federal de Medicina estabelecer e definir as normas éticas que regem a profissão do médico, cabendo aos Conselhos Regionais de Medicina o exercício do poder de polícia para a fiscalização das condutas dos profissionais e a aplicação de eventuais sanções quando houver a violação das regras aplicáveis. Portanto, a normativa emananda pelos Conselhos e aplicada aos profissionais médicos é plenamente legal e válida, inclusive as que dizem respeito à propaganda médica e que serão objeto de análise a seguir.

\subsection{Da normatização legal e deontológica da propaganda édica com enfoques nas redes sociais}

Pois bem, o tema em análise é de extrema importância, eis que dialoga com a natureza jurídica da relação médico-paciente e, por ser uma matéria bastante controvertida e complexa, muitos profissionais não conhecem as normas que regem o seu atuar e, por consequência, desconhecem os limites do exercício da profissão, especialmente quando realizado utilizandose as mídias sociais.

Além da mudança de paradigmas nas relações entre médicos e pacientes, os meios de comunicação atuais são bastante diferentes dos utilizados pelas sociedades do passado. Atualmente, grande parte da população do mundo está concetada à rede mundial de computadores, a internet, e com o surgimento das redes sociais, sendo o Brasil um dos países com mais usuários de tais ferramentas, o profissional da saúde passou a ter ampla visibilidade, seja para divulgar novas práticas ou métodos de tratamento médico, seja para divulgar informações aos pacientes.

Ocorre que os médicos devem se atentar aos conteúdos que produzem e publicam, a fim de que possam realizar suas atividades com base nas normas que disciplinam a profissão, porque a propaganda médica atinge uma relação extremamente delicada entre o profissional médico e o paciente, ou paciente em potencial, já que a relação entre os dois sujeitos se dá, geralmente, em momentos de grande fragilidade física e emocial de quem está recebendo ou procura receber os cuidados médicos. Nesse viés, a relação entre médico e paciente é, em regra, 
contratual, mas predominantemente, existencial e há a participação ativa de ambos os agentes, com o surgimento de direitos e deveres não patrimoniais, como os deveres de sigilo, de confidencialidade, de cuidado, de informação, motivo pelo qual é imprescindível a troca de informações e conhecimento com base nas normas cabíveis (MILDEMBERGER; PEREIRA, 2020, p. 201). Sendo assim, a propaganda realizada pelo médico deve ocorrer de modo diferenciado, pois o serviço prestado por esse profissional não possui natureza meramente patrimonial, visto que envolve a saúde, a vida humana e, como já mencionado alhures, a despeito de haver remuneração em razão de sua prestação, a relação entre médico e paciente tem natureza preponderantemente existencial.

Desta maneira, é necessária a regulamentação da propaganda médica, eis que o objeto do serviço prestado pelo médico não se trata se atividade exclusivamente financeira, tendo, em primeiro lugar, o intuito de proteção e manutenção de um bem e direito protegido diretamente pela Carta Magna de 1988: a saúde.

Por ser uma atividade profissional regulada por Lei que disciplina os requisitos, condições e limites para o seu exercício e por se tratar de profissão intrinsecamente voltada ao cuidado da saúde das pessoas, justifica-se a preocupação do legislador, inclusive o penal, em proteger a saúde pública diante daqueles que exercem essa profissão sem estar capacitado ou devidamente autorizado a fazê-lo.

Com dito linhas acima, com o advento da internet e das redes sociais, está cada vez mais frequente a veiculação de assuntos médicos na mídia. Há grande interesse da população por ditos assuntos, principalmente durante esse período de pandemia que assola o planeta há mais de um ano. Contudo, esse interesse despertado nas pessoas merece ser tratado com o mais amplo zelo. A necessidade de informar a sociedade, o paciente e potenciais pacientes sobre avanços científicos, tecnológicos, sobre o tratamento para determinada moléstia, como a Covid-19, bem como de divulgar a habilitação e capacitação do profissional médico não pode ultrapassar os limites legais e éticos.

Na sociedade em que vivemos, existe um grande apelo para o consumo, havendo, muitas vezes, em decorrência disso, uma diluição dos valores sociais, inclusive no âmbito profissional. Desta forma, a medicina deve atuar como garantidora dos princípios e valores da relação médico-paciente, impedindo os excessos e condutas que desvirtuem o seu real objeto, pois a mercantilização do ato médico compromete a existência da Medicina, do médico e do próprio paciente. Ora, não é contrário à ética divulgar e anunciar o trabalho do médico. O que fere a ética é a mercantilização da profissão. Sendo assim, a profissão médica no Brasil e, por 
conseguinte, a propaganda realizada pelos profissionais da Medicina tem regulação por normas jurídicas e éticas, mediante forte controle por parte dos conselhos de fiscalização que, conforme dito acima, possuem atribuições regulamentar e disciplinar amparadas na Constituição Federal de 1988 e em diversos diplomas legais já referenciados nesta pesquisa. Nesse cenário, o Conselho Federal de Medicina é, ao mesmo tempo, julgador e disciplinador da classe médica, cabendo-lhe zelar e trabalhar, por todos os meios ao seu alcance, pelo perfeito desempenho ético da Medicina, pelo prestígio e bom conceito da profissão e dos que a exerçam legalmente. Desta forma, referida autarquia estabelece critérios norteadores da propaganda médica, tendo como finalidade alcançar os objetivos ora elencados, evitando práticas sensacionalistas, de autopromoção e que expressem concorrência desleal.

Pois bem, ao realizar o anúncio médico, que pode ser entendido como a comunicação ao público das atividades profissionais por iniciativa, participação ou anuência do médico, alcançando atestados, avisos, boletins, declarações, fichas, formulários, receituários, etc., por qualquer meio de divulgação, o profissional deverá limitar-se a revelar os conhecimentos necessários ao público ajudando-o na luta contra as doenças, naquilo que é de interesse da saúde pública (FRANÇA, 2017, p. 198).

A propaganda do médico, nesse sentido, deverá ser realizada de forma sóbria, mediante divulgação simples e sem exageros na linguagem; deverá ser discreta, não podendo haver sensacionalismo ou exibicionismo por parte do médico; deverá ser pautada na veracidade científica e na legalidade, devendo respeitar, como já repisado nesta pesquisa, as normas que regem a profissão (FRANÇA, 2017, p. 199).

Nesse contexto, passemos então à análise da normativa acerca da propaganda médica no Brasil. O decreto- Lei $\mathrm{n}^{\circ} 4.113$, de 14 de fevereiro de 1942, o qual se encontra em vigor no ordenamento jurídico pátrio e foi recepcionado pela Constituição Federal de 1988, regulamenta a propaganda médica, doravante referida como publicidade médica. Essa Lei estabelece os critérios de controle sobre a informação a ser prestada pelos médicos quando da divulgação do tratamento de órgãos ou sistemas, ou ainda doenças específicas. Além disso, a normativa compele que esse tipo de propaganda delimite o vínculo entre o profissional e sua especialidade, bem como o material propagandístico de sua apresentação como médico. Nesse contexto, referido diploma legal, em seu artigo $1^{\circ}$ dispõe sobre as vedações impostas aos médicos ao realizar anúncios, sendo importante sua transcrição a seguir, confira-se:

Art. $1^{\circ}$ É proibido aos médicos anunciar:

I - Cura de determinadas doenças, para as quais não haja tratamento próprio, segundo os atuais conhecimentos científicos; 
II - Tratamento para evitar a gravidez, ou interromper a gestação, claramente ou em termos que induzam a estes fins;

III - exercício de mais de duas especialidades, sendo facultada a enumeração de doenças, órgãos ou sistemas compreendidos na especialização;

IV - Consultas por meio de correspondência, pela imprensa, caixa postal, rádio ou processos análogos;

V - Especialidade ainda não admitida pelo ensino médico, ou que não tenha tido a sanção das sociedades médicas;

VI - Prestação de serviços gratuitos, em consultórios particulares;

VII - sistematicamente, agradecimentos manifestados por clientes e que atentem contra a ética médica;

VIII - com alusões detratoras a escolas médicas e a processos terapêuticos admitidos pela legislação do país;

IX - Com referências a métodos de tratamento e diagnóstico não consagrados na prática corrente ou que não tenham tido a sanção das sociedades médicas;

$\mathrm{X}$ - Atestados de cura de determinadas doenças, para as quais não haja tratamento estabelecido, por meio de preparados farmacêuticos. (sem destaque no original).

$\S 1^{\circ}$ As proibições deste artigo estendem-se, no que for aplicável, aos cirurgiões dentistas.

$\S 2^{\circ}$ Não se compreende nas proibições deste artigo anunciar o médico ou o cirurgião dentista seus títulos científicos, o preço da consulta, referências genéricas à aparelhagem (raios-X, rádio, aparelhos de eletricidade médica, de fisioterapia e outros semelhantes); ou divulgar, pela imprensa ou pelo rádio, conselhos de higiene e assuntos de medicina ou de ordem doutrinária, sem caráter de terapêutica individual.

Verifica-se, portanto, que o objetivo dessas limitações é coibir a publicação de anúncios inverídicos, com promessas de cura para enfermidades incuráveis e tratamentos não aprovados pelos órgãos competentes, a autopromoção do médico, limitando o anúncio de apenas duas especialidades médicas e vedando a publicação sistemática de agradecimentos de pacientes, tudo isso, como forma de evitar a mercantilização da Medicina e de orientar o profissional médico no seu atuar, inclusive nas redes sociais.

Ademais, referido decreto estabelece que nos anúncios de casas de saúde, estabelecimentos médicos e congêneres, deve haver menção da direção médica responsável. Caso seja verificada irregularidade ou ilegalidade no anúncio, a autoridade sanitária responsável intimará o anunciante a observar as normas dentro de trinta dias, o que reflete uma finalidade educativa desse decreto. É nesse ânimo, demonstrando a preocupação com a possível ocorrência da mercantilização da Medicina, com a orientação aos profisisonais médicos e com a preservação da relação médico-paciente que o Conselho Federal de Medicina (CFM) publicou, em 19 de agosto de 2011, a Resolução 1.974/11 (com alterações da resolução $n^{0}$ 2.126/2015), a qual é considerada o verdadeiro manual de publicidade (propaganda) médica no País. Quando foi editada, mencionada Resolução expressou a preocupação de realização de propaganda médica divulgada em revistas, sites e programas de televisão. Com o surgimento e crescimento das redes sociais, essa preocupação se estendeu também à conduta do profissional médico ao utilizar as estruturas online, como as redes e mídias sociais. Esse diploma, enquanto 
ato normativo geral e abstrato, estabelece os critérios direcionadores da propaganda na Medicina, conceituando anúncios, a divulgação de assuntos médicos, o sensacionalismo, a autopromoção, bem como define as proibições atinentes à matéria. Desta forma, pode-se dizer que tal Resolução é insuscetível de lesar direito, já que tem o fim resguardar o exercício técnico e moral da profissão médica, bem como assegurar o interesse público, assim como regulamentar a ética na publicidade (propaganda) médica, ou seja, é pautado em dois pilares: de um lado o cuidado com o sensacionalismo e a autopromoção e de outro com o caráter informativo e científico da propaganda médica (HOLANDA; MATOS, 2021).

Assim, a propaganda veiculada pelo profissional médico deve obedecer exclusivamente a princípios éticos de orientação educativa, não podendo ser comparada à publicidade de produtos e práticas meramente comerciais. Nesse sentido, o Código de Ética Médica (Resolução $\left.n^{\circ} 2.217 / 2018\right)$, estabelece:

\section{Capítulo V \\ É vedado ao médico:}

Art. 37. Prescrever tratamento e outros procedimentos sem exame direto do paciente, salvo em casos de urgência ou emergência e impossibilidade comprovada de realizálo, devendo, nesse caso, fazê-lo imediatamente depois de cessado o impedimento, assim como consultar, diagnosticar ou prescrever por qualquer meio de comunicação de massa.

$\S 1^{\circ} \mathrm{O}$ atendimento médico a distância, nos moldes da telemedicina ou de outro método, dar-se-á sob regulamentação do Conselho Federal de Medicina.

$\S 2^{\circ}$ Ao utilizar mídias sociais e instrumentos correlatos, o médico deve respeitar as normas elaboradas pelo Conselho Federal de Medicina. (sem destaque no original).

Capítulo XIII

É vedado ao médico:

Art. 111. Permitir que sua participação na divulgação de assuntos médicos, em qualquer meio de comunicação de massa, deixe de ter caráter exclusivamente de esclarecimento e educação da sociedade.

Art. 112. Divulgar informação sobre assunto médico de forma sensacionalista, promocional ou de conteúdo inverídico.

Art. 113. Divulgar, fora do meio científico, processo de tratamento ou descoberta cujo valor ainda não esteja expressamente reconhecido cientificamente por órgão competente.

Art. 114. Anunciar títulos científicos que não possa comprovar e especialidade ou área de atuação para a qual não esteja qualificado e registrado no Conselho Regional de Medicina.

Art. 115. Participar de anúncios de empresas comerciais, qualquer que seja sua natureza, valendo-se de sua profissão.

Art. 116. Apresentar como originais quaisquer ideias, descobertas ou ilustrações que na realidade não o sejam.

Art. 117. Deixar de incluir, em anúncios profissionais de qualquer ordem, seu nome, seu número no Conselho Regional de Medicina, com o estado da Federação no qual foi inscrito e Registro de Qualificação de Especialista (RQE) quando anunciar a especialidade.

Parágrafo único. Nos anúncios de estabelecimentos de saúde, devem constar o nome e o número de registro, no Conselho Regional de Medicina, do diretor técnico. 
Nessa esteira de entendimento, a participação do médico na divulgação e propagação de assuntos médicos, em quaisquer meios de comunicação, inclusive nas redes sociais, deve se basear pelo caráter exclusivo de esclarecimento e educação da sociedade, não podendo haver o estímulo ao sensacionalismo, a autopromoção ou a promoção de outras pessoas, pacientes ou profissionais, a concorrência desleal, a exposição de pacientes, sempre garantindo a divulgação de conteúdo cientificamente comprovado, válido, pertinente e de interesse público.

Desta forma, para evitar conceitos subjetivos, na Resolução no 1.974/2011, encontramse as definições de sensacionalismo e autopromoção e as proibições referentes à matéria, conforme elencado a seguir.

O sensacionalismo define-se com a apresentação de técnicas e meios científicos que possam causar intranquilidade, pânico ou medo à sociedade, bem como, usar de forma abusiva, enganosa e sedutora representações visuais que possam induzir a promessas de resultados. Não respeitar conceitos éticos, divulgar métodos que não tenham reconhecimento científico, adulterar dados estatísticos visando beneficiar-se individualmente ou à instituição que representa, apresentar técnicas e métodos científicos que devem limitar-se ao ambiente médico, divulgar procedimentos, ainda que consagrados, de maneira exagerada e fugindo de conceitos técnicos para individualizar e priorizar sua atuação ou a instituição em que atua ou tem interesse pessoal e também utilizar mídia para divulgar métodos que não tenham reconhecimento científico.

Por sua vez, a autopromoção consiste na utilização nos meios de comunicação que visam captar clientela; fazer concorrência desleal; pleitear exclusividade de métodos diagnósticos e terapêuticos; auferir lucros de qualquer espécie e na divulgação do endereço e do telefone de consultório, clínica ou serviço.

Constata-se, portanto, que a propaganda médica jamais deve se restringir à busca do lucro. Deve ser realizada como forma de divulgação do trabalho oferecido pelo profissional médico. Ademais, toda a ação médica deve ter por objetivo o benefício do paciente. Trata-se de aplicação do princípio da beneficência, o qual, no caso concreto, dá-se por meio de uma propaganda que leve o paciente a obter apenas o bem e o melhor que a Medicina possa lhe oferecer (CODAME, 2021).

Além das vedações quanto às condutas sensacionalistas, autopromocionais e desleais, o artigo $3^{\circ}$ de dita resolução também proíbe que o médico exponha, principalmente nas redes sociais, a figura de seu paciente, ainda que haja autorização deste, ressalvada a hipótese de casos para apresentação de trabalhos científicos, com a devida autorização daquele, conforme 
disposto no artigo 10 desta resolução. Daí, observa-se que a conduta tão praticada por médicos, na atualidade, com a exposição de fotos, vídeos e imagens de "antes" e "depois" de procedimentos médicos e cirurgias realizados em pacientes, em anúncios médicos, é cabalmente proibida.

A vedação acima referenciada está prevista no artigo $3^{\circ}$, alínea g da resolução 1.974/2011 do Conselho Federal de Medicina e não exige Lei específica porque não se trata de condições ou qualificação para o exercício de profissão do médico. Ao contrário, visa preservar a ética profissional para o exercício da Medicina. É insuscetível de controle judicial de legalidade a violação de preceito ético previsto pelo órgão profissional legalmente competente.

São notoriamente sabidos os malefícios e dissabores causados com a divulgação de imagens e de procedimentos realizados em pacientes por seus médicos nas redes sociais, pois, além de haver exposição das pessoas em momentos de extrema fragilidade e em procedimentos íntimos, o que pode ferir os direitos à imagem e à dignidade humana, a conduta do profissional também pode configurar captação de clientela, pois, com a divulgação de um resultado em determinado indivíduo, essa publicação pode fazer crer que outra pessoa, com condições distintas e organismo diferente, poderá alcançar o mesmo resultado divulgado nas redes sociais.

Ademais, não é possível saber se o resultado divulgado pelo profissional adveio realmente da cirurgia e procedimento médico ou de manipulação das imagens e vídeos por meio de programas de computador.

A vedação contida na resolução em comento coíbe a mensagem que possa induzir em erro o paciente ao apresentar demonstrações ou garantias de cura ou de resultados sem efeitos adversos ou secundários. Verifica-se, ainda, que o uso da imagem do paciente, mesmo com autorização, constitui ilícito, pois o que se busca é o sigilo médico, a privacidade do paciente, evitando que a identificação do paciente sirva para angariar clientela em razão de eventual influência, até porque é vedada a mercantilização da profissão. Portanto, fácil constatar que essa publicidade indevida do "antes e depois" traz conseqüências negativas para ambos: médico e paciente. Transforma o resultado obtido em uma mercadoria. O médico se compromete em garantir o resultado do procedimento. Induz o paciente a um erro, desnatura a obrigação médica, como se fosse de resultado, porém, trata-se de obrigação de meio.

O profissional que assim atua, age fora dos padrões éticos e deontológicos que regem a profissão e também desvirtua o objetivo de sua atividade, que não pode ser mercantilizada e passa, ainda, a vincular sua atividade ao resultado oferecido e não apenas um meio para se atingir o desejo do paciente, sujeitando-se às penalidades legais cabíveis em caso de verificação 
de conduta danosa. Além da vedação acima elencada, é proibido ao médico anunciar especialização não reconhecida pelo Conselho Federal de Medicina ou especialização inexistente. Ora, o profissional devidamente inscrito no Conselho Regional de Medicina está apto ao exercício legal da Medicina, em qualquer de seus ramos; no entanto, só é lícito o anúncio de especialidade médica àquele que registrou seu título de especialista no conselho, pois o anúncio de múltiplas especialidades pode configurar a autopromoção do médico.

O profissional ao publicar anúncios médicos não pode, ainda, divulgar seu número de telefone nas redes sociais ou apontar outra atividade que não seja Medicina. Por exemplo, em sua página em uma rede social, o médico não pode se apresentar como profissional da medicina e coach, investidor, etc., pois, novamente, a autopromoção e o sensacionalismo configuram práticas temerárias.

Consoante a normativa analisada, ao utilizar as redes sociais, o médico não pode "repostar" fotos, imagens e publicações de pacientes acerca de procedimentos por ele realizados, nem agradecimentos recorrentes ou as famosas selfies, porque, mais uma vez, essas práticas podem expressar uma forma de captação de clientes nas redes sociais, de autopromoção do médico e até de sensacionalismo, o que, como já foi amplamente explicitado neste artigo, é expressamente proibido pelas normas que regem a Medicina.

Além da Resolução 1.974/2011 acima examinada quanto à propaganda médica, o Conselho Federal de Medicina já havia editado outros diplomas acerca do assunto. A título de informação, a Resolução 788/1977 determina aos Conselhos Regionais de Medicina que, em caso de publicidade de organização ou pessoa jurídica que não obedeça às resoluções do CFM, seja instaurado processo ético-profissional contra o respectivo diretor-médico e principal responsável.

Já a Resolução 1.595/2000 proíbe a vinculação da prescrição médica ao recebimento de vantagens materiais oferecidas por agentes econômicos interessados na produção ou comercialização de produtos farmacêuticos ou equipamentos na área médica. Por sua vez, a Resolução 1.633/2002 dispõe sobre a proibição de matérias publicitárias vinculadas á área médico-hospitalar e afins, nos jornais e/ou revistas editadas pelos conselhos de medicina.

Por seu turno, a Resolução 1.836/2008 veda ao médico o atendimento de pacientes encaminhados por empresas que anunciem e/ou comercializem planos de financiamento ou consórcio para procedimentos médicos. Finalmente, o anexo da resolução 097/2001 do Conselho Regional de Medicina do Estado de São Paulo (CREMESP) elenca os princípios éticos para sites de medicina e saúde na internet, a saber: transparência, honestidade, qualidade, 
consentimento livre e esclarecido, privacidade, ética médica, responsabilidade e procedência. Sendo assim, é possível constatar a vasta regulamentação sobre a propaganda médica pelo Conselho Federal de Medicina, autarquia responsável pela fiscalização da profisssão médica e aplicação das sanções cabíveis no caso de infração ás normas apontadas.

Realizado o estudo das Resoluções do Conselho Federal de Medicina sobre a propaganda médica, cabe aqui tecer breves comentários a respeito da Lei nº 13.874/19.

Pois bem, com a entrada em vigor da Lei de liberdade econômica, Lei 13.874/19, restou gerado o questionamento se esse diploma legal afetaria as regras emanadas pelos Conselhos de Medicina para regular a publicidade e propaganda médica, já que devem ser asseguradas a liberdade e menos intervenção estatal nas atividades econômicas, pelo que o artigo $4^{\circ}$, VIII da referida Lei estabelece ser dever da Administração Pública e demais entidades evitar o abuso no poder regulatório de maneira a restringir o uso e o exercício da publicidade e propaganda sobre um setor econômico, ressalvadas as hipóteses expressamente vedadas em Lei federal.

Ocorre que a Lei de liberdade econômica não pode ser aplicada ao profissional médico, pois, o próprio diploma legal ressalva os casos em que existe previsão de Lei expressa regulamentando determinado setor profissional, como é o que ocorre com a atividade médica, seja por Lei em sentido estrito, seja por normas deontológicas que tem força normativa e são editadas com amparo na própria Constituição Federal a qual confere poder de polícia ao conselho profissional (artigo $5^{\circ}$, XIII).

Desta forma, as Resoluções do Conselho Federal de Medicina se alicerçam em princípios éticos que visam a evitar a concorrência desleal, a autopromoção, o sensacionalismo e a mercantilização da Medicina, evitando publicidade e anúncios abusivos, afastando, assim, a incidência de referida Lei aos médicos. Ademais, o Conselho Federal de Medicina, em nota aos médicos e à sociedade, publicada em 25 de setembro de 2019 , já se pronunciou no sentido de não incidência da Lei de liberdade econômica na publicidade médica, pois o objeto da atuação do médico é a saúde do ser humano e das coletividades humanas, em benefício da qual deverá agir com o máximo de zelo, com o melhor de sua capacidade profissional e sem discriminação de qualquer natureza, assim,a atividade médica não deve ser considerada de maneira finalística como atividade econômica/financeira.

Desta forma, entendeu que, no caso das normas éticas, inclusive as que versam sobre publicidade (propaganda) médica e outras matérias, a regulamentação exercida pelos Conselhos de Medicina não é indevida, nem busca restringir o mercado de trabalho e a liberdade econômica, tendo por principal objetivo a proteção da saúde da população e o perfeito 
desempenho ético da Medicina, conforme expressa previsão legal. Portanto, toda a regulamentação do CFM em relação à matéria ética, especialmente quanto à publicidade médica, continua válida, com fundamento expresso, e referendada pelo Poder Judiciário (CFM, 2019).

Coforme explanado ao longo deste artigo, o médico deve pautar sua conduta com base nas normas que regulam sua profissão, se abstendo de realizar as práticas vedadas pelos diplomas legais. Diante disso, caso incorra nas vedações supracitadas, pode haver a instauração de sindicância para apurar o fato, que pode ser instaurada de ofício ou mediante denúncia escrita ou verbal, sendo o profissional chamado para prestar esclarecimentos perante o Conselho de Medicina ao qual é vinculado. Nesse caso, pode haver pedido para que seja firmado um Termo de Ajustamento de Conduta ou pode ser instaurado um processo administrativo em face do profissional, que poderá culminar na aplicação das sanções previstas nas normas, dentre as quais, a cassação do registro profissional em razão de condutas reiteradas.

Nas esferas judiciais, cível e criminal, a publicidade (propaganda) indevida de médicos que prometem cura, resultados, etc., pode gerar sua responsabilização, com a conseqüente aplicação de penalidades e o reconhecimento de responsabilidade e dever de indenizar em casos de insucessos nos procedimentos médicos.

Portanto, a infração às normas jurídicas atinentes á propaganda profissional, na sua conformação civil, penal, administrativo-disciplinar e ético profissional, tem como conseqüências jurídicas: a obrigação de reparação do dano civil, material e moral, sanção essa aplicada pelo juiz de direito; sanção penal com as penas de detenção e multa aplicadas pelo juiz criminal; a sanção administrativa disciplinar aplicada pela autoridade competente; a sanção ético-disciplinar aplicada pelo conselho regional de medicina competente com recurso ao Conselho Federal de Medicina. Realizadas as considerações a respeito da normativa sobre propaganda médica, serão delineadas as práticas de utilização das redes sociais pelos médicos em conformidade com a ética médica e com a Lei.

\subsection{Da possibilidade de realização de propaganda médica nas redes sociais dentro dos limites legais e éticos}

A rede mundical de computadores consiste em um dos meios de comunicação em massa mais ágeis e com capacidade de difusão de informações em grande escala. Em razão da facilidade e amplo acesso à internet, qualquer indivíduo pode criar um sítio e disponibilizar os 
mais variados tipos de informações a qualquer pessoa, inclusive, em tempo real, através de vídeos, transmissões ao vivo (lives), etc. Desta maneira, a informação, na atualidade, é fundamental para qualquer atividade profissional inclusive para o desempenho do trabalho dos médicos, pois a rede mundial de computadores também está mudando a forma de trocas de informações sobre saúde. Todavia, como já demonstrado nesta pesquisa, há limites para que essas informações sejam propaganda pelo profissional da Medicina.

Conforme mencionado neste artigo, a propaganda relativa ao exercício da Medicina integra o conceito de liberdade profissional, garantida nos termos e limites legais e daqueles estabelecidos pelas normas editadas pelos Conselhos de Medicina, consoante previsão do art. $5^{\circ}$, XIII, da Constituição Federal.

Sendo assim, o médico tem direito de fazer propaganda de suas habilitações profissionais, desde que observe os ditames legais e deontológicos que regem sua profissão, os quais refletem normas permissivas e proibitivas, que limitam a propaganda na sua forma, conteúdo e finalidade, porque a atividade médica jamais pode ser mercantilizada.

Flamínio Fávero, em sua obra Noções de Deontologia Médica e Medicina Profissional declara que o médico tem, naturalmente, direito de anunciar, mas deve ser sóbrio, comedido, recatado, pudico nesses reclamos, quer nos títulos, quer na especialidade, quer nas dimensões, quer na forma, quer nas promessas, quer no local onde põe o anúncio, lembrando sempre que é o representante de uma profissão sobremaneira digna, honesta e respeitável (FAVERO, s.d, p. 162).

Desta forma, a comunicação e a propaganda médica devem ser socialmente responsáveis, transmitindo informações precisas e éticas, já que a sociedade espera que o profissional médico expresse uma comunicação honesta e não o interesse em conquistar mercado por meio de estratégias da mídia e, ao aprimorar a qualidade da propaganda médica, dentro dos padrões éticos, os profissionais da Medicina ficarão mais fortes e respeitados pela sociedade (CFM, 2019).

Ora, não restam dúvidas que a divulgação de novas técnicas diagnósticas e terapêuticas, novos procedimentos médicos, novos tratamentos para as enfermidades aos pacientes e à população em geral, é um dos aspectos mais importantes da propaganda médica, pois ela pode e deve ter um efeito educativo para quem recebe a informação, sendo sempre uma propaganda positiva e não meramente promocional de quem anuncia. É fundamental, para que isso aconteça, que a propaganda não se afaste da verdade, ou seja, apenas deve ser divulgado o que é cientificamente correto e aceito como boa prática médica (CFM, 2019). Para o médico, a 
propaganda pode ser um instrumento de o profissional se tornar conhecido pela sociedade, pois, seguindo a normativa da profissão, pode fazer ser conhecido e oferecer seus serviços à comunidade e aos pacientes em potencial.

Desta forma, considerando que as informações veiculadas sobre saúde, procedimentos médicos, novas técnicas, novos tratamentos para enfermidades, dentre outros serviços, podem garantir a melhora da saúde dos indivíduos ou, até mesmo provocar danos àqueles, os profissionais que propagam informações na rede mundial de computadores, em especial nas redes sociais, tem o dever de veicular conteúdos verdadeiros, de qualidade, bem como devem seguir a normativa aplicada à profíssão, respeitando o sigilo médico, a privacidade e imagem do paciente, etc.

As informações médicas veiculadas em sítios online, bem como nas redes sociais devem ser estritamente educativas e com o escopo de prestar esclarecimentos à sociedade. Os médicos, desta forma, estão obrigados a seguir a regulamentação legal no que concerne à propaganda médica.

Poderá haver a aplicação de sanções ao profissional pelo Conselho Médico caso o médico utilize as redes sociais para realizar a autopromoção, buscando a captação de clientela, caso realize a concorrência desleal, divulgando, por exemplo, promoções no valor de consultas e procedimentos, pleiteie exclusividade de métodos diagnósticos ou terapêuticos, faça propaganda de determinado produto, equipamento ou medicamento, em troca de vantagem econômica oferecida por empresas ou pela indústria farmacêutica, estimule o sensacionalismo, prometendo cura de doenças para as quais a medicina ainda não possui recursos, divulgue métodos, meios e práticas experimentais ou alternativas que não tenham reconhecimento científico, exponha o paciente através de fotografias, videos ou os famosos "antes e depois".

Ante todas essas vedações, pergunta-se: é possível que o médico faça propaganda nas redes sociais? A resposta é claramente afirmativa. Ora, como já dito acima, o médico, enquanto profissional, tem o direito de divulgar informações para a sociedade, desde que o faça nos ditames legais e éticos.

Desta maneira, para que a propaganda médica possa ser realizada, os princípios deontológicos devem ser preservados, respeitados e cumpridos, devendo o médico realizar a divulgação de idéias e informações com discrição, verdade, zelo e respeito ao paciente e seus direitos. Não pode o profissional mercantilizar a atividade médica. Deve, todavia, fazer propaganda com o intuito de seguir o princípio bioético da beneficência. Sendo assim, pode ser realizada a propaganda médica desde que não haja excesso, não haja sensacionalismo, não haja 
autopromoção, não haja comercialização do ato médico, não haja mercantilização da medicina. Desde que, como já bastante repisado nesta pesquisa, sejam observados os princípios éticos e legais com o intuito de esclarecer, elucidar e educara comunidade.

O médico deve informar a população sobre as novidades na Medicina, mas essa divulgação não pode ter o caráter de autopromoção ou de mercantilização da atividade médica.

O profissional médico pode conceder entrevista à televisão e rádio, com o intuito de esclarecer à sociedade levando informação de utilidade pública e poderá divulgar, inclusive em sua página nas redes sociais, seu nome completo, sua especialidade, com a indicação do número de seu registro de qualificação de especialização (RQE) e número do CRM acompanhado na unidade da federação onde possui inscrição. Todavia, é vedado fornecer telefone ou endereço do consultório.

O médico não pode se utilizar dos meios de comunicação e das redes sociais para divulgar métodos e tratamentos não reconhecidos cientificamente, como o milagroso soro para tratar a Covid-19, por exemplo.

É vedado ao médico publicar foto durante o ato médico relatando o que será executado ou o que acabou de executar, com pessoas identificáveis como celebridades, vinculando seu nome ou da clínica, pois tal atitude configura autopromoção. É vedado, ainda expor foto do paciente para divulgar técnica do antes e depois, já que o ato é considerado como quebra de sigilo profissional, autopromoção, concorrência desleal e promessa de resultado. Fotos, vídeos e imagens de procedimentos médicos apenas podem ser apresentados em reuniões científicas (congressos) e após a obtenção de consentimento do paciente. O médico devidamente inscrito perante o Conselho regional de Medicina está apto a exercer sua profissão em qualquer área médica, porém, é vedado anunciar nos meios de comunicação e redes sociais o exercício de mais de duas especialidades, sendo facultada a enumeração de doenças, órgãos ou sistemas abrangidos na especialização.

Do mesmo modo, o médico que não possuir título de especialista em determinada área não pode divulgar em seus anúncios especialidades que não possua. Não pode haver a divulgação de preços, modalidades de pagamento, descontos, como forma de estabelecer um diferencial nos serviços prestados com relação aos demais profissionais médicos. A divulgação de preços e parcelamentos não pode ser utilizada como forma de angariar clientes, porque configura concorrência desleal e pode expressar a mercantilização da Medicina.

Deve-se evitar comentários sobre a marca de produtos e tratamentos, não podendo o profissional médico participar de anúncios publicitários e comerciais de qualquer natureza, 
especialmente de produtos, equipamentos ou medicamentos em troca de vantagens econômicas oferecidas por empresas ou indústria farmacêutica. Nas redes sociais, como já dito, é vedado ao médico expor seus pacientes, porém, o profissional pode usar desenhos, animações, bonecos, infinitas imagens digitais que não sejam pacientes para ilustrar técnicas e procedimentos, por exemplo.

Nessa esteira de entendimento, também é vedada a publicação de selfies do profissional e do profissional acompanhados de seus pacientes, bem como proíbe-se a utilização de "repostagem" de fotos e de elogios recorrentes publicados por pacientes nas redes sociais, pois configura-se autorpromoção e captação de clientela pelo médico, duas condutas que vão de encontro á normativa legal e deontológica sobre o tema.

Portanto, será permitido ao médico divulgar em redes sociais informações, entrevistas, vídeos e postagens sobre artigos com assuntos médicos, com a utilização de textos curtos acompanhados de imagens ilustrativas, sempre com finalidade educativa, divulgando cursos e atualizações realizadas, desde que relacionados a especialidades ou áreas de atuação, sempre com as exigências estabelecidas pelos Conselhos de Medicina e em obediência às normas legais e éticas que regem a profissão. Recomenda-se que o médico separe o perfil profissional do pessoal nas redes sociais, a fim de que sejam obedecidas as normas que regem a profissão.

\section{Considerações finais}

A sociedade atual é considerada como a sociedade da informação, sendo essencialmente informática e comunicacional. Em razão do surgimento de novas tecnologias vive-se um momento de intensa troca de informações sobre os mais variados assuntos entre os indivíduos, principalmente através da rede mundial de computadores e essa tendência abrange todos profissionais que integram a comunidade.

A relação entre médico e paciente também acompanha essa evolução tecnológica e informacional. Desta forma, ao exercer sua profissão e realizar a propaganda médica, é imprescindível que o médico tenha conhecimento das normativas éticas, bem como devem ser obedecidos os ditames legais que regem a profissão, para que sejam preservados os princípios deontológicos, bioéticos e legais, como o escopo de ser realizada sempre uma prática da Medicina de maneira saudável, atual, ética e compatível com a evolução digital e com os tempos modernos. O profissional da Medicina deve sempre pautar sua atuação na regulamentação existente, podendo divulgar seus feitos de forma informativa, educativa e elucidativa, tendo a 
consciência de que o interesse público é primordial e sempre que este for atingido por ato individual haverá a sanção correspondente pelo Estado ou por quem detém competência para tanto, como é o caso dos Conselhos Profissionais, não cabendo assim, no atuar do médico, o sensacionalismo, a autopromoção e a concorrência desleal.

Todo anúncio e propaganda realizados pelo médico devem ter como baliza as informações de qualidade para o público em geral, divulgadas com comprometimento, sobriedade, veracidade e clareza, de maneira que o profissional possa se colocar no mercado competitivo de forma idônea, sem se desvincular do objetivo principal da medicina: a saúde e vida humanas.

Portanto, ao realizar suas atividades dentro dos limites legais e deontológicos estabelecidos, o médico cumpre seu papel como importante profissonal na comunidade, preservando e zelando a Medicina e a sociedade em geral, sendo a propanda nas redes sociais uma realidade plenamente possível.

\section{Referências}

BRASIL. Constituição da República Federativa do Brasil. Brasília: Senado, 1988.

BRASIL. Decreto no 20.931, de 11 de janeiro de 1932. Regula e fiscaliza o exercício da medicina, da odontologia, da medicina veterinária e das profissões de farmacêutico, parteira e enfermeira, no Brasil, e estabelece penas. Disponível em: http://www.planalto.gov.br/ccivil 03/decreto/1930-1949/d20931.htm. Acesso em: 02 fev. 2021.

BRASIL. Decreto- Lei $\mathbf{n}^{\circ}$ 4.113, de 14 de fevereiro de 1942. Regula a propaganda de médico, cirurgiões dentistas, parteiras, massagistas, enfermeiros, de casas de saúde e de estabelecimentos congêneres e a de preparados farmacêuticos. Disponível em: https://www2.camara.leg.br/legin/fed/declei/1940-1949/decreto- Lei-4113-14-fevereiro-1942414086-publicacaooriginal-1-pe.html. Acesso em 23 jan. 2021.

BRASIL. Lei no 12.842, de 10 de julho de 2013. Dispõe sobre o exercício da Medicina. Disponível em: http://www.planalto.gov.br/ccivil_03/_ato2011-2014/2013/Lei/112842.htm. Acesso em 22 jan. 2021.

BRASIL. Lei no 13.874/19, de 20 de setembro de 2019. Institui a Declaração de Direitos de Liberdade Econômica; estabelece garantias de livre mercado; altera as Leis $n^{\underline{o s}} 10.406$, de 10 de janeiro de 2002 (Código Civil), 6.404, de 15 de dezembro de 1976, 11.598, de 3 de dezembro de 2007, 12.682, de 9 de julho de 2012, 6.015, de 31 de dezembro de 1973, 10.522, de 19 de julho de 2002, 8.934, de 18 de novembro 1994, o Decreto- Lei $\mathrm{n}^{\circ}$ 9.760, de 5 de setembro de 1946 e a Consolidação das Leis do Trabalho, aprovada pelo Decreto- Lei $\mathrm{n}^{\circ}$ 5.452, de $1^{\circ}$ de maio de 1943; revoga a Lei Delegada $n^{\circ}$ 4, de 26 de setembro de 1962, a Lei $\mathrm{n}^{\mathrm{o}} 11.887$, de 24 de dezembro de 2008, e dispositivos do Decreto- Lei $\mathrm{n}^{\mathrm{o}} 73$, de 21 de 
novembro de 1966; e dá outras providências. Disponível em: http://www.planalto.gov.br/ccivil_03/ ato2019-2022/2019/ Lei/L13874.htm. Acesso em 01 fev. 2021.

BRASIL. Lei $\mathbf{n}^{\mathbf{0}}$ 3.268, de 30 de setembro de 1957. Dispõe sobre os Conselhos de Medicina e dá outras providências. Disponível em: http://www.planalto.gov.br/ccivil_03/leis/13268.htm. Acesso em 23 jan. 2021.

CODAME. ÉTICA EM PUBLICIDADE MÉDICA, 2. ed. Responsabilidade na publicidade médica. Disponível em: http://feridologo.com.br/manual_do_Codame_2_Ed_Site.pdf. Acesso em 09 fev. 2021.

CONSELHO FEDERAL DE MEDICINA. Código de Ética Médica. Resolução CFM n ${ }^{\circ}$ 2.217/2018. Disponível em: https://portal.cfm.org.br/images/PDF/cem2019.pdf. Acesso em 23 jan. 2021.

CONSELHO FEDERAL DE MEDICINA. Nota aos médicos e à sociedade. Aspectos positivos da publicidade médica. Disponível em:

http://www.crmdf.org.br/index.php?option=com_content\&view=article\&id=21798:2019-0926-20-48-51\&catid=3. Acesso em 08 fev. 2021.

CONSELHO FEDERAL DE MEDICINA. Nota aos médicos e à sociedade. Esclarecimentos sobre as regras da publicidade / propaganda médicas. Disponível em: http://www.crmdf.org.br/index.php?option=com_content\&view=article\&id=21798:2019-0926-20-48-51\&catid=3. Acesso em 08 fev. 2021.

CONSELHO FEDERAL DE MEDICINA. Nota aos médicos e à sociedade.

Responsabilidade na publicidade médica. Disponível em:http://www.crmdf.org.br/index.php?option=com_content\&view=article\&id=21798:201909-26-20-48-51\&catid=3. Acesso em 08 fev.2021.

CONSELHO FEDERAL DE MEDICINA. Resolução 1.595/2000. Disponível em: https://sistemas.cfm.org.br/normas/visualizar/resolucoes/BR/2000/1595. Acesso em 30 jan.2021.

CONSELHO FEDERAL DE MEDICINA. Resolução 1.633/2002. Disponível em: https://sistemas.cfm.org.br/normas/visualizar/resolucoes/BR/2002/1633. Acesso em 01 fev. 2021.

CONSELHO FEDERAL DE MEDICINA. Resolução 1.836/2008. Disponível em: https://sistemas.cfm.org.br/normas/visualizar/resolucoes/BR/2008/1836. Acesso em $01 \mathrm{fev}$. 2021.

CONSELHO FEDERAL DE MEDICINA. Resolução 1974/2011. Disponível em: https://portal.cfm.org.br/publicidademedica/arquivos/cfm1974_11.pdf. Acesso em 23 jan. 2021. 
CONSELHO FEDERAL DE MEDICINA. Resolução 788/1977. Disponível em: https://sistemas.cfm.org.br/normas/visualizar/resolucoes/BR/1977/788. Acesso em 30 jan.2021.

CONSELHO FEDERAL DE MEDICINA. Resolução CFM n 2.126/2015. Disponível em: https://sistemas.cfm.org.br/normas/visualizar/resolucoes/BR/2015/2126. Acesso em 23 jan. 2021.

\section{CONSELHO REGIONAL DE MEDICINA DO ESTADO DE SÃO PAULO. Resolução} 097/2001. Disponível em:

http://www.cremesp.org.br/?siteAcao $=$ PesquisaLegislacao \&dif $=$ s\&ficha $=1 \& \mathrm{id}=3217 \&$ tipo $=\mathrm{R}$ ESOLU\%C7\%C3O\&orgao=Conselho $\% 20$ Regional $\% 20 \mathrm{de} \% 20$ Medicina $\% 20 \mathrm{do} \% 20$ Estado $\%$ $20 \mathrm{de} \% 20 \mathrm{~S} \% \mathrm{E} 3 \mathrm{o} \% 20$ Paulo\&numero $=97 \&$ situacao $=$ VIGENTE $\&$ data $=20-02-2001$. Acesso em 01 fev. 2021.

DANTAS, E. Direito Médico. 4. ed. rev.atual. e ampl.Salvador: Editora Juspodivm, 2019. FAVERO, F. Noções de deontologia médica e medicina profissional. Rio de Janeiro: Pimenta de Melo, [s. d.]. 302p. (Coleção Médico-Cirurgia, 162).

FRANÇA, G. V. Direito Médico. Editora Forense, 14 ed. Rio de Janeiro, 2017.

FRANÇA, G. V. A velha e a nova ética médica. Disponível em: http://www.anml.org.br/diversos/. Acesso em 25 jan. 2021.

GONÇALEZ, M. C. Publicidade e propaganda. IESDE BRASIL S, A: Curitiba, 2009.

HOLANDA, C. A.; MATOS, M. L. V. Deontologia médica e mídias sociais: Breves considerações sobre o atuar dos profissionais da medicina frente às novas formas tecnológicas na publicidade da sociedade contemporânea. In: DANTAS, E.; CORRÊA, F. A - J., (coord.). Tendências do Direito Médico. Rio de Janeiro: GZ Editora; 2021.

LESSA, P. G. Tudo O Que Você Precisa Saber Sobre Direito Médico E Saúde. Rio de Janeiro: G Z Editora, 2020.

MILDEMBERGER, C. S.; PEREIRA, P. M. F. de L. Publicidade Médica Nas Mídias Sociais: proposta de Um Modelo Contemporâneo No Brasil. In: NETO, M. K.; NAGAROLI, R. (coord.). Debates contemporâneos em direito médico e da saúde. São Paulo: Ed. Revista dos Tribunais, 2020.

NETO, M. K.. Responsabilidade Civil do Médico.10. ed.rev.ampl.São Paulo: Editora Revista dos Tribunais, 2019.

SUPREMO TRIBUNAL FEDERAL. Notícias STF. Disponível em: http://www.stf.jus.br/portal/cms/verNoticiaDetalhe.asp?idConteudo=384048. Acesso em 25 de janeiro de 2021.

We are social. Digital 2020: global digital Year book. Disponível em: https://datareportal.com/reports/digital-2020-brazil. Acesso em: 22 jan. 2021. 


\title{
FORMAÇÃO DO PROFESSOR E AS METODOLOGIAS ATIVAS
}

\section{TEACHER TRAINING AND ACTIVE METHODOLOGIES}

\author{
GERVASIO, Cirlene Ferreira Neri ${ }^{1}$ \\ MEYER, Marcel $^{2}$ \\ SILVA, Katia Cristina da ${ }^{3}$ \\ SOUZA, Ana Maria Reis de ${ }^{4}$
}

SOUZA, Michele Ronsane Fanezzi de ${ }^{5}$

\section{Resumo}

Objetivos: Esse artigo trata das metodologias ativas e a formação dos professores para trabalhar com novas informações, novas metodologias, que são necessárias para acompanhar o interesse do aluno em um ensino mais interativo e motivado. Se constata que a educação básica no Brasil cada dia mais se apresenta de maneira transformada diante do dinamismo de uma sociedade que se transforma a cada instante com as informações recebidas nessa era de globalização onde a competição com a mídia já permeia o espaço escola, exigindo desse espaço de educação uma reconstrução constante de suas diretrizes exigidas pela própria sociedade como um todo. Diante do desenvolvimento do pensamento humano dispersado nas diversas maneiras de compreensão das pessoas, isso leva a mudanças necessárias no sentido de colocar a educação no patamar da contemporaneidade. Conclusão: A pesquisa bibliográfica recorre a vários autores que se dedicaram ao tema e conclui que existe a necessidade de formação de professores para atuar nessa nova mentalidade de educar que exige uma mudança de percepção de como ensinar partindo das necessidades e vontade do aluno em aprender.

Palavras chave: Metodologias Ativas. Formação. Professor.

\begin{abstract}
Objectives: This article deals with the active methodologies and the training of teachers to work with new information, new methodologies, which are necessary to follow the student's interest in a more interactive and motivated teaching. It is evident that basic education in Brazil is being transformed every day, due to the dynamism of a society that is constantly changing with the information received in this era of globalization, where competition with the media already permeates the school space, demanding from this educational space a constant reconstruction of its guidelines required by society itself as a whole. In the face of the development of human thought dispersed in the various ways people understand, this leads to necessary changes in order to place education at the level of contemporaneity. Conclusion: The bibliographical research resorts to several authors who have dedicated themselves to the theme and concludes that there is a need for training teachers to act in this new mentality of educating, which requires a change in perception of how to teach based on the student's needs and will to learn.
\end{abstract}

Key words: Active Methodologies. Formation. Educator.

\footnotetext{
1 Pedagogia UFMG, mestranda Universidad de la Empresa - UDE

2 Bacharel em administração, MBA em gestão de projetos mestrando Universidad de la Empresa - UDE

3 Pedagogia UEMG, mestranda Universidad de la Empresa - UDE

${ }^{4}$ Pedagogia, mestranda Universidad de la Empresa - UDE

5 Administração e pós graduada em educação a distância, mestranda Universidad de la Empresa - UDE
}

RCMOS - Revista Científica Multidisciplinar O Saber. ISSN: 2675-9128. São Paulo, v. 02, n. 2, p. 01-12, fev. 2021. 


\section{Introdução}

$\mathrm{Na}$ sociedade do conhecimento a aprendizagem requer um aprendiz critico, criativo, autônomo com capacidade de formar opinião. Nesse sentido surgem vários estudos apontando novas metodologias que pretendem investir na formação e preparação do educando para exercer a sua autonomia, entre elas a Metodologias Ativas que se utilizam da problematização como meta para motivar o aprendiz a desenvolver reflexões de ideias mediante ao problema apresentado, relacionando sua história, sua realidade oportunizando uma ressignificação das suas descobertas para que possa aplicá-la na prática. A problematização leva o educando, ou integrante de atividades, a refletir sobre a informação produzindo o conhecimento com o objetivo de solucionar as dúvidas e inquietações relacionadas aos problemas enfrentados, os desafios, promovendo, assim, o seu próprio desenvolvimento a partir da construção e reconstrução do saber.

Este artigo de metodologia bibliográfica, tem o objetivo de refletir sobre as metodologias ativas e a formação do professor frente as novas informações, pois, para a aprendizagem é importante que os participantes estejam preparados para assumir um ensino mais participativo, onde os participantes já se relacionem, principalmente que exista proximidade entre professor e aluno, pois a aprendizagem acontece nas relações formadas, na troca de afetividade, na motivação e no empenho para alcançar os objetivos traçados. Em relação à realização, entende-se como função da escola formar seus alunos de modo encaminhálos na conquista de suas aspirações, principalmente no campo profissional, sem deixar de lado a formação como cidadão, com valores, princípios e ética.

O ensino precisa de liberdade para progredir, ter a opção de criatividade e construção do saber, de forma espontânea, sem cobrança respondendo aquilo que ele realmente sabe e absorveu com associações de sua vivencia. Não cabe mais as respostas decoradas e sem sentido para quem responde. Nesse sentido a aprendizagem só terá valor se for suficiente para permitir que o aluno se desenvolva livremente, explorando suas potencialidades.

Nesse sentido se questiona se: a formação de professores tem sido frequentemente considerada a partir de critérios técnicos que visam, em primeiro lugar, atender a necessidade de mudança de paradigmas se inserindo nas novas informações?

A oportunidade de reflexão proporcionada ao professor é muito importante, pois, a educação não é mais tratada como algo estanque, onde se elabora um currículo que deve ser seguindo sem alterações, a nova realidade requer reflexão e ação dos docentes, para que seja 
tratado na escola, na sala de aula os interesses dos alunos, seguir sim um conteúdo programado, mas sem deixar que esse conteúdo seja estranho à realidade dos envolvidos.

\section{Fundamentação teórica}

\subsection{A formação de professores}

Conforme Cunha (2003) a formação dos professores vem sendo, principalmente a partir da década de 1990, alvo de muitas discussões. Motivo que deu origem a muitas pesquisas centralizando investigações, procurando encontrar "bons professores", "professores competentes", "professores reflexivos", ou seja, educadores que em sala de aula apresentam um fazer pedagógico coerente com concepções progressistas de educação.

Entretanto, as pesquisas têm revelado o quanto à prática pedagógica destes profissionais pode ser ressignificada à luz das novas concepções de educação. Garcia (2003, p.22), se refere sobre o assunto, dizendo que "a docência, se considera uma profissão, é necessário, tal como noutras profissões, assegurar que as pessoas que a exerçam possuam competência profissional".

Faz-se necessário ressaltar que por muito tempo a formação oficial não teve a preocupação de incentivar a relação entre teoria e prática docente. Inicialmente, contentava-se em "reciclar" o educador, descartando o seu conhecimento real, introduzindo o novo desconectado do velho, oferecendo cursos rápidos e descontextualizado, somado a palestras e encontros esporádicos superficiais (GARCIA, 2003).

Nas reflexões de Garcia (2003) ainda se encontra que mais tarde, coerente com o momento histórico por qual passava a concepção de educação, contentou-se em "treinar" o educador tendo como eixo central à modelagem de comportamentos, desencadeando ações apenas com finalidades mecânicas. Ao educador era atribuída a tarefa de fazer e não de pensar, impondo-se modelos, receitas, técnicas do fazer pedagógico. Buscando superar a dinâmica das formações anteriores surge, na década de 80 , novos conceitos de se pensar/fazer tal processo: "aperfeiçoamento" e "capacitação" de educadores. Coerente com tais conceitos, novas decisões foram tomadas e novas ações propostas. Porém para alguns educadores, tais estratégias de formar ainda não respondem as demandas de uma prática pedagógica transformadora.

Ao refletir-se sobre o verdadeiro sentido da palavra aperfeiçoar, (GARCIA, 1999) alude que se chega ao tornar perfeito, completar o que estava incompleto. No conceito de capacitação, 
tornar capaz, parece existir, também, uma doutrinação, inculcação de ideias como sendo verdades absolutas que precisam ser, simplesmente, aceitas, exercendo uma função curativa, remediadora e imediatista.

Hargreaves (1998), se referiu as regras do mundo que estavam mudando, portanto, era hora das regras do ensino e do trabalho docente mudarem também. Freire (1982), Nóvoa (2002) e Perrenoud (2003) se referem à; "formação permanente" e ou "formação continuada". Estes dois termos podem ser considerados similares, pois pontuam como eixo central a pesquisa em educação, valorizam o conhecimento do professor, e em um processo interativo/reflexivo, buscam contribuir para uma análise do próprio fazer docente.

Freire (1982), sempre se preocupou com a formação do povo, tendo a escola como fonte onde essa educação pode ocorrer, e contemplar a realidade do educando, ele diz : a "ultrapassar a visão fragmentada da realidade, levando as pessoas a superar o individualismo através da cooperação, das soluções coletivas, da liberdade de pensamento, tornando-se cidadãos, avançando de uma "consciência ingênua para uma consciência crítica" (FREIRE, 1982, p.24), a busca nesse contexto é por uma mobilização social que questione o próprio sistema e transforme a realidade.

Nóvoa (2002), defende que o educar/formar nesta perspectiva é reconhecer, os professores a partir de três eixos estratégicos: a pessoa do professor e sua experiência; a profissão e seus saberes, e a escola e seus projetos. “A formação não se constrói por acumulação (de cursos de conhecimento ou de técnicas), mas sim através de um trabalho de reflexão crítica sobre práticas e de (re)construção permanente de uma identidade pessoal" (NÓVOA, 2002, p.38).

Portanto, é necessário que se respeite os professores como pessoas, seres em constante formação, eternos aprendizes, que a partir de uma formação contextualizada buscam transformar-se, entender o grupo no qual estão inseridos e ressignificar a suas práticas pedagógicas. Desta forma Marin (2007, p.2), diz:

Não se trata de uma simples aquisição de conhecimentos, mas de uma transformação da própria pessoa envolvendo mecanismos psicológicos mais amplos, e essa interação sujeito-mundo (local onde habito e no qual dou e recebo significações) é que faz aparecerem problemas mais profundos, os quais a simples instrução não consegue resolver. É necessária uma prática transformadora constituída pela teoria e pela ação, formando uma proposta pedagógica que não concebe as pessoas como 'destinatárias' mas como sujeitos da própria atividade política.

Conforme relata Marin (2007) busca-se uma nova competência pedagógica, surgida a partir da reflexão e sobre a prática, que em um movimento de ação-reflexão-ação, caminha para 
uma menor dicotomia teoria/prática, entendendo sempre que entre uma determinada teoria que se quer assumir e a prática que se quer ressignificar existe a teoria do sujeito, a qual se constrói a partir das indagações daquilo que faz.

Enfim, é fundamental que o educador seja auxiliado a refletir sobre sua prática, a organizar suas próprias teorias, a compreender as origens de suas crenças para que possa tornarse pesquisador de sua ação, um profissional reflexivo, que melhorando o seu trabalho em sala de aula, recria constantemente sua prática. Precisa-se, fazer notar que a prática reflexiva do professor, aliada a atitudes de meta-aprendizagem por parte dos alunos só significará um substancial melhora na qualidade dos conhecimentos adquiridos na escola, se essa postura não se der numa perspectiva individual no espaço escolar.

Moraes (2000), aponta para a importância de formar professores desde que estes estejam abertos a uma mudança de postura quanto ao seu papel, promovendo a equiparação de oportunidades e de direitos de seus alunos, o que extinguirá todo e qualquer comportamento agressivo e promoverá o desenvolvimento não só cognitivo, como também social e afetivo dos mesmos.

Faz-se necessário ressaltar que por muito tempo a formação oficial não teve a preocupação de incentivar a relação entre teoria e prática docente. Inicialmente, contentava-se em "reciclar" o educador, ignorando o seu conhecimento real, introduzindo o novo conhecimento desconectado do já adquirido, oportunizando cursos rápidos e descontextualizados da realidade, somados a palestras e encontros esporádicos superficiais. Mais adiante, coerente com o momento histórico por qual passava a concepção de educação, contentou-se em "treinar" o educador tendo como eixo central à modelagem de comportamentos, tendo como resultado ações apenas com finalidades mecânicas. Nesse contexto, ao educador era atribuída a tarefa de fazer e não de pensar, impondo-se modelos, receitas, técnicas do fazer pedagógico.

$\mathrm{Na}$ atualidade se percebe a existência de uma educação com nova roupagens, totalmente diferenciada da educação do século passado. Essas novas características levaram a mudanças significativas interferiram de forma contundente na forma do professor ensinar e a forma da qual o aluno compreende. Nesse sentido, os pesquisadores, teóricos da educação definiram várias teorias importantes e diversos modos de encarar a sala de aula, passando pelas metodologias tradicionais, as relacionadas com a as técnicas, as que levam em conta a interação entre os pares e as próprias Metodologias Ativas que conforme Berbel (2011) são formas de 
desenvolver o processo de aprender, se utilizando de experiências, sejam elas reais ou simuladas, tendo em vista às condições de encontrar solução, enfrentando os desafios originados das atividades essenciais da prática social, em diferentes contextos.

\subsection{Metodologias ativas}

Um período importante para a educação foi identificado no movimento da Escola Nova, onde se fortaleceu com os inúmeros seguidores, que aprovaram a ideia de um ensino focado no aluno, demandando metodologias ativas e criativas (DEWEY, 1959). Aprender é próprio do aluno: só ele aprende, e por si; portanto, a iniciativa lhe cabe. O professor é um guia, um diretor; pilota a embarcação, mas a energia propulsora deve partir dos que aprendem (DEWEY, 1979, p.43).

Também se referem às metodologias ativas os autores Barbosa e Moura (2013), que dizem que a aprendizagem ativa ocorre por meio da interação do aluno com o assunto estudado, ouvindo, falando, perguntando, discutindo, fazendo e ensinando, sendo estimulado a construir o conhecimento ao invés de recebê-lo passivamente. Nesse sentido, ao aplicar os aprendizados em contextos diferentes daqueles em que foram obtidos se exigirá mais do que simples decoração ou solução mecânica de exercícios. Será exigido o domínio de conceitos, flexibilidade de raciocínio e capacidades de análise e abstração. Ao realizar tais reflexões, o aluno terá uma maior clareza sobre o conteúdo. Futuramente, esse conhecimento construído não precisará ser retomado, apenas relembrado (ZABALA, 2001).

A aprendizagem ativa (Active Learning), na definição de Bonnell e Eison (1991), é um termo genérico que surgiu para expressar as múltiplas atividades elaboradas para envolver os alunos em realizar e pensar sobre as tarefas que eles estão fazendo nos processos de aprendizagem. Nesse mesmo sentido Silberman (1996) ensina que a Active Learning é um método de pedagogia de engajamento, onde se busca o comprometimento dos alunos na aprendizagem.

Conforme define Hunh (2015), a aprendizagem ativa reúne uma enorme gama de atividades educacionais, com motivadoras estratégias e métodos ensino, e ainda qualquer abordagem pedagógica onde se pretende ativar ou desenvolver o pensamento crítico dos alunos no processo de aprendizagem. Com as abordagens dos autores acima citado, pode-se entender Metodologias Ativas como mecanismos que os professores lançam mão em prol da 
aprendizagem do aluno, a motivação, envolvimento, interação. A utilização dessas metodologias pode favorecer a autonomia, despertar a curiosidade, estimular tomadas de decisões individuais e coletivas. E, o que se considera muito importante, reverter os índices de repetência escolar, o que é considerado a possível causa da evasão de alunos.

As metodologias ativas são uma nova maneira de pensar o ensino tradicional. Isso porque um dos princípios da Base Nacional Comum Curricular (BNCC) que deve guiar o currículo de toda a Educação Básica brasileira incentiva a promoção do aluno como protagonista de seu processo de ensino-aprendizagem. Portanto, as metodologias ativas surgem como uma alternativa para proporcionar aos estudantes meios para que eles consigam guiar o seu desenvolvimento educacional, fugindo do modelo de ensino em que o professor detinha todo o conhecimento dentro da sala de aula.

Ao se referir sobre os desafios da educação voltados às novas diretrizes educacionais e centrados na competência do professor, Souza (2009) diz que o período é de transição decorrente da presença de inúmeros desafios que envolvem diferentes dimensões, como as culturais, sociais, políticas, morais e espirituais. Essa busca de novas compreensões sobre a aprendizagem leva a busca de um novo referencial para a educação. A aprendizagem exige a compreensão do conteúdo pelo aluno e isso se dá através da construção de redes de relações em um sistema onde cada novo conhecimento é inserido pelo aluno, ampliando ou modificando o sistema inicial.

Conforme relata Pereira (2012), além da educação básica, essas metodologias têm sido amplamente divulgadas em universidades do exterior e implantadas em instituições do Brasil. A sua utilização induz a que os alunos se interessem mais pelas aulas, pois por meio dessa abordagem, sua curiosidade é despertada devido à utilização de situações de seu cotidiano, trazendo novas descobertas construídas a partir de informações já disponíveis ao aluno (BORGES; ALENCAR, 2014).

Ao se referir sobre as metodologias ativas, Mitre et al. (2008), esclarece que elas se apoiam na problematização como impulso estratégico para a motivação do discente no processo de ensino/aprendizagem, pois quando enfrenta um problema e se sente estimulado a resolver, ele se detém, estuda atentamente, reflexiona, relaciona com a sua vivência e passa a fazer a ressignificação e encontrar caminhos para a resolução, através de inúmeras descobertas.

Ao ser confrontado com uma situação problema o aluno pode ser levado ao contato com as informações e possibilidade de produzir conhecimento, principalmente, com o objetivo 
superar os impasses e promover o seu próprio desenvolvimento. Portanto, aprender por meio da problematização e/ou da resolução de problemas é uma das possibilidades de envolvimento ativo dos alunos em seu próprio processo de formação (MITRE et al. 2008),

Essas novas metodologias, que representam a educação nos tempos atuais, deixam explícitos a carência de formação dos professores, cursos que os capacitem e impulsione ao enfrentamento de novos desafios, o que reflete nas Metodologias Ativas. Paulo Freire (1996) faz uma defesa das metodologias ativas, quando afirma que na educação de adultos, o que impulsiona a aprendizagem é a superação de desafios, a resolução de problemas e a construção do conhecimento novo a partir de conhecimentos e experiências prévias dos indivíduos.

Ainda existem resistência por parte de muitos educadores no reconstruir sua prática já ultrapassada por um ensino mais dinâmico e interativo, pois, para as Metodologias Ativas passarem a fazer parte do cotidiano educacional, cumprindo com a intencionalidade pela qual são pensadas, é necessário, principalmente, que os educadores, atores principais do processo de formação dos educandos dentro da escola, as assimilem, no sentido de compreendê-las e acreditarem no seu potencial pedagógico e se mostrem disponíveis, tanto intelectual como afetivamente, valorizando uma reconstrução do processo educacional para trabalharem conforme a proposta.

Dessa forma, o papel do professor é extremamente relevante, visto que, lhe acrescentam responsabilidades fazendo-o sair da zona de conforto, deixando de lado os estilos de trabalho convencionais. De acordo com a literatura da área motivacional, é pouco provável que os estudantes, em situação escolar, envolvam-se espontaneamente em todas as atividades de aprendizagem de modo autônomo, com grande interesse, alegria ou prazer (GUIMARÃES, 2003). A interação entre os professores é uma das principais fontes o fortalecimento e incentivo dos alunos, a motivação se constrói na confiança e empatia entre professores e alunos, facilitando a interação em sala de aula, possibilitando a valorização das atividades e conteúdos propostos e a internalização das exigências ou demandas externas.

Com o ambiente de colaboração os estudantes passam a ter prazer na realização de um trabalho e o realiza com presteza e qualidade, o que contribui para a motivação individual e coletiva, o que é associado com processamento das informações, criatividade, persistência, preferência por desafios, entre outros resultados positivos. Como os alunos não são todos iguais é necessário também um planejamento diferenciado, que cada etapa possa ter sentido para agregar todos os alunos. Nesse sentido se justifica a necessidade de o professor buscar 
diferentes alternativas que contenham, em sua proposta, as condições de provocar atividades que estimulem o desenvolvimento de diferentes habilidades de pensamento dos alunos e possibilitem a atuação nas situações que promovem a autonomia, substituindo, sempre que possível, as situações de controle e direcionamento implícito e explicito. Cabe ao professor, se inserir nas formas mais dinâmicas de ensinar para junto com seus alunos aproveitarem os benefícios das Metodologias Ativas.

No entender de Pimenta e Anastasiou (2005) a aula é um momento privilegiado, onde será construído o conhecimento através das ações conjuntas entre professor e aluno. É necessário um trabalho conjunto entre os professores e alunos, sendo fundamental que o professor conheça, organize as atividades de ensino, pois a ação do aluno será realizada de acordo com as suas mediações.

Tornar os alunos responsáveis pela própria aprendizagem implica que eles deverão desempenhar uma série de tarefas. Woods (1994) relaciona as seguintes: a) explorar o problema, levantar hipóteses, identificar e elaborar as questões de investigação; b) tentar solucionar o problema com o que se sabe; c) identificar o que não se sabe e o que é preciso saber para solucionar o problema; d) priorizar as necessidades de aprendizagem, estabelecer metas e objetivos de aprendizagem e alocar recursos de modo, a saber, o que, quanto e quando é esperado e, para a equipe, determinar as tarefas individuais; e) planejar, delegar responsabilidades para o estudo autônomo da equipe; f) compartilhar o novo conhecimento para que todos os membros aprendam os conhecimentos pesquisados pela equipe; f) aplicar o conhecimento para solucionar o problema; e g) avaliar o novo conhecimento, a solução do problema e a eficácia do processo utilizado, refletindo sobre o processo.

Portanto, é necessário que se adote metodologias que favoreçam o envolvimento em atividades cada vez mais inovadoras e complexas, nas quais os alunos tenham que acompanhar todo o desenrolar, mantendo o foco em cada etapa e resultados. Se o objetivo é que os alunos sejam criativos, é necessário oferecer a eles inúmeras e diferentes possibilidades de mostrar sua iniciativa e capacidade de criar. Em relação as Metodologias Ativas, Smith (et.al. 2005) relataram que educadores, pesquisadores e formuladores de políticas têm defendido o envolvimento dos alunos durante algum tempo como um aspecto essencial da aprendizagem significativa. Neste sentido as metodologias de aprendizagem ativa são uma forma de atrair e envolver os alunos. Portanto, a importância das Metodologias ativas está expressa nas palavras de muitos autores quando Morán (2015) argumenta que há muito tempo, teóricos como Dewey 
(1979), Freire (2009), Rogers (1973), Novack (1999), entre outros, enfatizam, a importância de superar a educação bancária, tradicional e focar a aprendizagem no aluno, envolvendo-o, motivando-o e dialogando com ele. Berbel (2011) relata que as Metodologias Ativas se baseiam em formas de desenvolver o processo de aprender, utilizando experiências reais ou simuladas, visando às condições de solucionar, com sucesso, desafios que vem das atividades essenciais da prática social, em diferentes contextos.

Nos argumentos de Candau (1991) a escola se vê mergulhada em sua insuficiência e em sua luta de sobrevivência cotidiana, os problemas da comunidade aumentam, neste contexto o estudante não é preparado para lidar, a interferir em tais problemas, ficando a margem dos fatos. As metodologias ativas são defendidas por Freire (1996), quando afirma que, para que haja educação, a superação de desafios, a resolução de problemas e a construção de novos conhecimentos a partir de experiências prévias, são necessárias para impulsionar as aprendizagens.

\section{Considerações finais}

Analisando as necessidades de um novo direcionamento na área educacional, buscando a aprendizagem com a participação do foco principal que é o aluno, é importante fazer uma reflexão sobre a necessidade de formação dos professores para se inserirem nessa abordagem cada vez mais inovadora e dinâmica que é a educação. A intervenção que deve ser feita, a nível da formação contínua que, em caso algum, pode deixar de fora, as dúvidas, as dificuldades, as preocupações, que surgem dentro da escola, fazendo com que a metodologia ganhe novos rumos, como no caso das metodologias ativas.

Assim, este estudo buscou conhecer um pouco mais das Metodologias Ativas e fazer uma ponte com a necessidade de formação dos professores, pois somente com um pessoal capacitado que se pode dar sentido as novidades que surgem em todas as áreas, principalmente, no caso abordado que é a educação. E também provocar uma reflexão quanto a pratica educativa e a importância da busca por estudos de formação. Nessa época em que as crianças, adolescentes e jovens em idade escolar, passam grande parte do dia conectado e sentado em frente a um computador, celular, interagindo com pessoas diversas ou participando de atividades recreativas, é importante que a escola ofereça um ensino atrativo, com capacidade de despertar a atenção e envolver os educandos e atividades prazerosas que tenham sentido na vida real dele. Nesse sentido, este estudo representa também um processo de crescimento, onde se busca uma 
forma mais abrangente de conhecimento, sem que não haja exclusão e sim união dos profissionais da educação em busca do aperfeiçoamento cultural.

\section{Referências}

BARBOSA, E. F.; MOURA, D. G. Metodologias ativas de aprendizagem na Educação Profissional e Tecnológica. Boletim Técnico do Senac, 2013.

BERBEL, N. A. N. As metodologias ativas e a promoção da autonomia de estudantes. Seminario: Ciências Sociais e Humanas, 2011.

BONWELL, C. C., e EISON, J. A. Active learning: creating excitement in the classroom. Washington: Eric Digests, 1991.

BORGES, T. S.; ALENCAR, G. Metodologias ativas na promoção da formação crítica do estudante: o uso das metodologias ativas como recurso didático na formação crítica do estudante do ensino superior. Cairu em Revista, 2014.

CANDAU, V. Repensando a Didática. Campinas, São Paulo, Papirus, 1991.

CUNHA, M. I. da. O bom professor e sua prática. São Paulo: Papirus, 2003.

DEWEY, J. Experiência e educação. São Paulo: Editora Nacional. São Paulo: Companhia Editora Nacional, 1979.

FREIRE, P. Educação como prática da liberdade. Rio de Janeiro: Paz e Terra, 2009.

FREIRE, Paulo. Pedagogia do oprimido. São Paulo: Paz e Terra, 1982.

FREIRE, P. Pedagogia da Autonomia: saberes necessários à prática educativa. São Paulo: Paz e Terra, 1996.

GARCIA, C. M. Formação de Professores para uma mudança educativa. Porto Alegre: Artemed, 2003.

GUIMARÃES, A. A inclusão que funciona. Nova Escola: a revista do professor, São Paulo, ano xviii, n. 165, p. 42-47, set. 2003.

HARGREAVES, A. Os professores em Tempos de Mudança. Amadora: Editora McGraw Hill de Portugal, L., 1998.

HUNG, H.-T. Flipping the classroom for English language learners to foster active learning. Computer Assisted Language Learning, v. 28, n. 1, 81-96, 2015.

MARIN, A. J. Educação continuada: introdução a uma análise de termos e concepções. Cadernos CEDES, n. 36, 2007. 
MITRE, S. M., et. al, Metodologias ativas de ensino-aprendizagem na formação profissional em saúde: debates atuais. Ciência \& Saúde Coletiva, 2008.

MORAES, R. Construtivismo e ensino de ciências: Reflexões epistemológicas e metodológicas. Porto Alegre: Edipucrs, 2000.

MORÁN, J. M. Mudando a educação com metodologias ativas. In: SOUZA, C. A.; TORRESMORALES, O. E. (org.). Convergências midiáticas, educação e cidadania: aproximações jovens. Ponta Grossa, PR: UEPG, 2015.

NOVAK, J. D.; GOWIN, D. B. Aprender a aprender. 2. ed. Lisboa: Plátano Edições Técnicas. 1999.

NÓVOA, A. (org.). Os professores e sua formação. Lisboa: Dom Quixote, 2002.

PEREIRA, R. Método Ativo: Técnicas de Problematização da Realidade aplicada à Educação Básica e ao Ensino Superior. Anais do VI Colóquio Internacional "Educação e Contemporaneidade", São Cristóvão, 2012.

PERRENOUD, P. Práticas pedagógicas, profissão docente e formação: perspectivas sociológicas. Lisboa: Dom Quixote, 2003.

PIMENTA, S.G.; ANASTASIOU, L.G.C. Docência no Ensino Superior. 2. ed. São Paulo: Cortez, 2005.

ROGERS, C. Liberdade para Aprender. Belo Horizonte: Ed. Interlivros, 1973.

SILBERMAN, M. Active learning: 101 strategies do teach any subject. Massachusetts: Ed. Allyn and Bacon, 1996.

SMITH, K. A., SHEPPARD, S. D., JOHNSON, D. W.; JOHNSON, R. T. Pedagogies of engagement: Classroom-based practices. In ASEE Journal of Engineering Education, volume 94, 2005.

SOUSA, S. M. Z. L. de. Avaliação e gestão da educação básica no Brasil: da competição aos incentivos. In: DOURADO, L. F. (Org.). Políticas e gestão da educação no Brasil: novos marcos regulatórios. São Paulo: Xamã, 2009.

WOODS, D. Problem-Based Learning: how to get the most out of PBL. Hamilton: W. L. Griffen Printing Limited, 1995.

ZABALA, A. Enfoque Globalizador e Pensamento Complexo: uma proposta para o currículo escolar. Porto Alegre, RS: Artmed, 2001. 


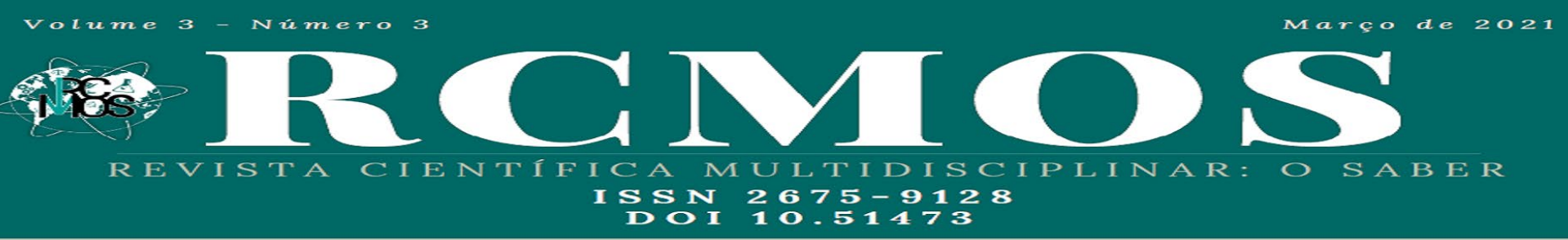

\title{
UTILIZAÇÃO DA TECNOLOGIA COMO ESTRATÉGIA DE CONSTRUÇÃO DO PENSAMENTO
}

\section{UTILIZATION OF TECHNOLOGY AS A STRATEGY FOR THE CONSTRUCTION OF THOUGHT}

\author{
GERVASIO, Cirlene Ferreira Neri ${ }^{1}$ \\ GOES, Mayara Eleuterio ${ }^{2}$ \\ MEYER, Marcel $^{3}$ \\ SOUZA, Alessandra Cândido Ciza de ${ }^{4}$ \\ SOUZA, Ana Maria Reis de ${ }^{5}$ \\ SOUZA, Michele Rosane Fanezzi de ${ }^{6}$
}

\section{Resumo}

Este artigo trata sobre a tecnologia e seu uso como estratégia para incentivar a construção do pensamento, de forma criativa e dinâmica. A sociedade contemporânea vive em meio às tecnologias e tem sido impactada pelo princípio da multiplicidade onde todos se veem ligados a uma rede. Nessa perspectiva, a tecnologia é um poderoso mecanismo no processo educacional, auxiliar na mediação entre as metodologias de facilitação como se comportam as atividades relacionadas à leitura e à escrita quando a tecnologia entra em cena. A rapidez e a evolução dessas possibilidades, por vezes, podem não observar que se está envoltos numa teia de inteligências que podem sobrepor, equilibrar-se ou antepor a essas estratégias como maneiras eficazes de se almejar resultados. Para construção dessa reflexão se recorreu a pesquisa bibliográfica, buscando várias fontes de pesquisa. É necessário se ater aos fins que se deseja quanto ao resultado final a se esperar e conhecer, quais contribuições têm sido relevantes como mediadoras eficazes no incentivo ao desenvolvimento intelectual.

Palavras chave: Tecnologia. Educação. Construção do Pensamento.

\begin{abstract}
This article deals with technology and its use as a strategy to encourage the construction of thought, in a creative and dynamic way. Contemporary society lives in the midst of technologies and has been impacted by the principle of multiplicity where everyone is connected to a network. In this perspective, technology is a powerful mechanism in the educational process, assisting in the mediation between the facilitation methodologies as the activities related to reading and writing behave when technology enters the scene. The speed and evolution of these possibilities, at times, may not observe that one is involved in a web of intelligences that can overlap, balance or precede these strategies as effective ways to aim for results. To construct this reflection, bibliographic research was used, looking for various
\end{abstract}

\footnotetext{
${ }^{1}$ Mestre Universidade Interamericana - PY - Paraguai, e-mail gervasiocirlene@gmail.com

${ }^{2}$ Mestranda Universidad de la Empresa - UDE UY, Uruguai, e-mail analistamayara@gmail.com

${ }^{3}$ Mestrando Universidad de la Empresa - UDE UY, Uruguai, e-mail profmarcelmeyer@gmail.com

${ }^{4}$ Mestranda Universidad de la Empresa - UDE UY, Uruguai, e-mail aleciza@gmail.com

${ }^{5}$ Mestranda Universidad de la Empresa - UDE UY, Uruguai, e-mail anamelreis1965@gmail.com

${ }^{6}$ Mestranda Universidad de la Empresa - UDE UY, Uruguai. e-mail mfanezzisouza@htmail.com
} 


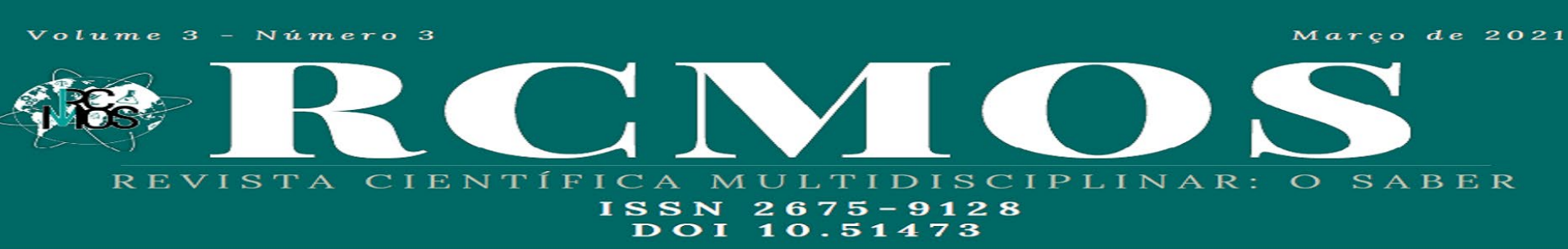

sources of research. It is necessary to stick to the ends that are desired as to the final result to be expected and to know, which contributions have been relevant as effective mediators in encouraging intellectual development.

Keywords: Technology. Education. Construction of Thought.

\section{Introdução}

A Tecnologia não causa mudanças apenas no dia a dia do ser humano, mas também em no comportamento, na forma como se elabora conhecimentos e no relacionamento com o mundo. Vive-se num mundo tecnológico, onde se estrutura as ações através da tecnologia.

Neste estudo, se considera a tecnologia como estratégia de fomento a construção do pensamento através da leitura e escrita entendendo como tais ferramentas impactam nessa formação quando observadas de forma direta através da motivação e interesse, e ainda assim, como estas tecnologias se apresentam em seu contexto social e educacional. As tentativas de uso do computador na educação escolar vão desde a simples digitação de uma redação manuscrita, ao uso de softwares prontos, como também e felizmente, através de projetos educacionais com um enfoque interdisciplinar. Este último é resultado de um trabalho integrado, processado pelos alunos e mediado pelo educador.

Não se pode mais ignorar que o computador faz parte da vida de muitas pessoas, e não somente da vida profissional como também da vida pessoal. Muitos se comunicam mais por email do que por telefone. A digitação de uma tese, dissertação ou trabalho teórico ficou muito mais eficiente e ágil depois da propagação do editor de texto. Sem falar nas possibilidades inúmeras de inserção de figuras, gráficos, vídeos, fotos, entre tantas outras.

Entretanto, apesar dos benefícios do computador e suas ferramentas na sociedade atual, o sistema educacional ainda tem dificuldade em descobrir uma maneira produtiva e eficiente de se trabalhar com este instrumento na rotina escolar. A escola não pode, portanto, ficar à margem da evolução tecnológica. É nesse contexto que surge hoje a Informática educativa, menos como uma ciência ou disciplina e mais como uma nova linguagem de comunicação com o mundo.

\section{Fundamentação teórica}

2.1 A tecnologia aliada à educação

A tecnologia, surge como um meio para oportunizar diversos meios de resolver questões ou auxiliar resolvê-los, concretizando o sentido de sua função social. O avanço tecnológico 


\section{Volume 3 - Número 3

empregado a equipamentos eletrônicos agrega uma nova percepção sobre a tecnologia, a qual pode ser identificada também como novas tecnologias na sociedade da informação. Se tornando cada dia mais abrangente e com ovas possibilidades de informação, o que faz com que mais usuários se agreguem usufruindo de saberes em tempo real, em informações e distrações a cada dia mais complexas e desafiadoras.

Nesse sentido a escola sofre uma competição que podemos considerar desleal, pois os mecanismos encontrados fora da escola são mais atraentes que do ensino da sala de aula. Surge a necessidade de a escola se reinventar, e oferecer ao seu público um ensino de qualidade associado à sua realidade. Um currículo que faça sentido aos alunos, que tenham familiaridade, e com a consciência que nossa vida não é só tecnologia, existem momentos que o ser humano é o centro das atenções, por sua criatividade e capacidade de resolver problemas e mudar as suas perspectivas de vida e da sociedade onde vive.

Nessa realidade em que se vive, onde é necessário estar preparado para interagir com as várias e diferentes formas de informações, a educação semeia estratégias para cumprir com sua função de formar, educar, preparar e instruir para a vida. Ao delimitar na educação a função da escrita, em destaque, Lévy (2011) corrobora com Vygotsky (1993) quando diz que "todas as pessoas são capazes de aprender, mas é preciso que adaptemos a nossa prática de ensino às necessidades dos indivíduos e do contexto onde eles estão inseridos" (VYGOTSKY, 1993, p. 17).

É pela prática segura dos meios auxiliares de ensino e conhecimento pleno de seus mecanismos que se alcança a concreção do ensino. Essa prática é essencialmente esperada pelo professor. De acordo com Libâneo (1994), sem essa dinâmica, dialogar com as novas gerações será uma expressão pouco concreta.

São as ações do professor pelas quais se organizam as atividades de ensino e dos alunos para atingir objetivos do trabalho docente em relação a um conteúdo específico. Eles regulam as formas de interação entre ensino e aprendizagem, entre o professor e os alunos, cujo resultado é a assimilação consciente dos conhecimentos e o desenvolvimento das capacidades cognoscitivas e operativas dos alunos (LIBÂNEO, 1994, p. 161).

Silva (2010), se refere a Pedagogia do Parangolé para contribuir na compreensão sobre a experimentação efetiva de métodos e técnicas como meios auxiliares a educação, quando relaciona o movimento de experimentar ou interagir com o objeto de sua expressão, ou seja, quando se utiliza um meio tecnológico para alcançar um objetivo educacional. Nesse sentido, 


\title{
Votume 3 - Número 3

pode-se dizer que está corroborando com uma pedagogia da experimentação ou uma Pedagogia do Parangolé à luz da tecnologia.

A Pedagogia do Parangolé é experimentada intensamente pelo indivíduo, por exemplo, quando se compromete em uma finalidade interativa com seu equipamento diante de uma tela ou de uma máquina que interage facilitando a produção e leitura de conteúdo de relevância, tornando-se autores de um processo educacional. Difere-se desse processo, por exemplo, prostrar-se frente a uma televisão e simplesmente receber informações, mesmo que relevantes, uma vez que não se experimenta o equipamento de forma interativa. A essência da interação entre a máquina e sua função educativa é o que traz significância a esta teoria.

Contudo, para que as estratégias formativas sejam alcançadas é preciso explorar a ciência da educação de forma consolidada. Neste campo, a didática cumpre com seu papel desenvolvendo as estratégias adequadas e ativando as motivações as quais abrirão as capacidades cognitivas. Ao abordar a didática geral Gascón e Labra (2008), resumem as estratégias e dimensões a serem alcançadas:

Quadro 1 - Estratégias e dimensões

a) Estratégias do tipo físico e psicomotor: afetam o corpo e seu desenvolvimento, se referem mais à físiologia.

b) Estratégias do tipo cognitivo ou intelectual: refere-se à atenção, à participação dos alunos por meio da comunicação das intenções, à interpretação, à atividade de reforço e à realimentação.

c) Estratégias do tipo social: produção de boas relações humana sendo uma primeira condição. A segunda condição envolve a participação de todos os envolvidos: tratamento amistoso, sentido de pertença, compartilhamento de objetivos e experimentação da satisfação ao alcançar os êxitos individuais e coletivos.

d) Estratégias do tipo emocional: despertam o entusiasmo, a satisfação e bem estar pela satisfação em realizar as atividades que se propõem, permitem que o elogio estabeleça o bom sentimento nas partes do processo.

e) Estratégias que afetam a personalidade: baseiam-se na manutenção e desenvolvimento da autoestima. A autoestima traz um conceito positivo, a avaliação que cada um faz de sua autopercepção, como valoriza a forma em que vê a si mesmo, relaciona-se à aceitação ou à não aceitação.

\section{Fonte: Adaptado de Gascón e Labra (2008)}

Ao se referirem sobre o alcance de resultados propostos para a didática, Gascón e Labra (2008, p.191) argumentam:

\begin{abstract}
Notamos que as estratégias que funcionam bem um dia com alguns alunos com outros podem falhar, com um grupo ou alunos individuais. Mas há um estilo que nunca falha, a longo prazo: valorização das pessoas, apreciá-los, confiar neles, partilhar com eles uma paixão para as disciplinas que lecionam. Tudo o que é sinceramente a causa para cada aluno. Ela representa o estilo da partilha e colaboração, acompanhando e estimulando o crescimento pessoal com as técnicas mais adequadas e estratégias.
\end{abstract}

Portanto, entende-se que as estratégias não são findas em si mesmas, intervir nas motivações é requisito para se ter sucesso em estratégias didáticas. As motivações individuais 


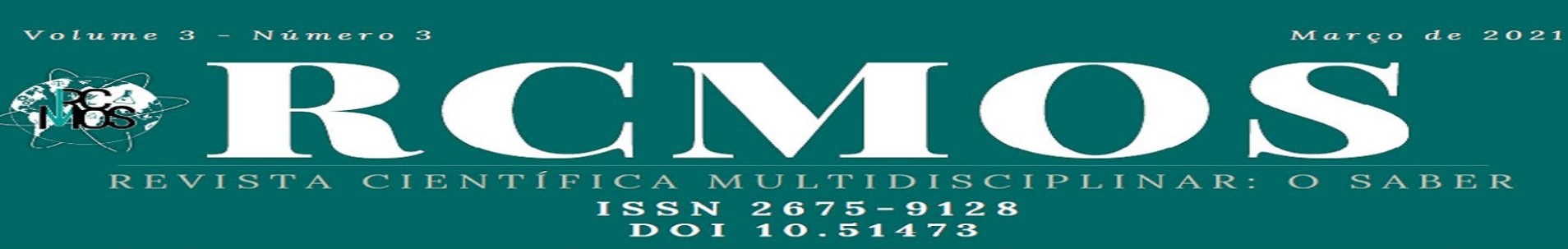

na sociedade do conhecimento estão ligadas a conceitos de redes, hipertextos, autonomia, amplitude, colaboração. A reconstrução deste paradigma se abre a novos valores e novos padrões de comportamento a serem entendidos como naturais, dinâmicos e como parte de uma estrutura nova da ser planejada pelas ciências da educação.

Uma nova classe de propostas de intervenções se relaciona com um conjunto de tecnologias, entre as consideradas tradicionais e as consideradas novas, uma nova classe de estratégias contempla o equilibro dessa transição.

\subsection{A tecnologia e os novos significados}

A tecnologia veio para ficar e transformar o cotidiano das pessoas. Com informações a tempo real, novas alternativas, aparelhos cada dia mais sofisticados com recursos até a pouco tempo inimagináveis. Mas essas "novidades" nem sempre chegam aos ambientes educacionais, o que seria primordial, pois é onde se formam as pessoas para exercer a sua cidadania de forma igualitária a todos os cidadãos.

Quando a tecnologia é inserida no espaço educacional compõe um emaranhado de perfis geracionais, máquinas e equipamentos, padrões de valores, comportamentos e estratégias e tantos outros recursos midiáticos à disposição de uma educação proativa e renovadora, o que se espera nas salas de aulas, laboratórios de escolas, onde ao coordenar a diversidade de fenômenos aliados à educação é ampliado o desafio de promover a fruição da leitura e da escrita para se efetivar a formação com competência.

Portanto, com o advento tecnológico fica evidente a necessidade de compreender e dominar os novos significados trazidos por esta tecnologia, seja nas escolas, nas universidades ou nos ambientes corporativos, identificando a influência que esses equipamentos exercem nas atividades sociais tanto por meio da televisão, de aplicativos de celular e de programas de computador e diversas abordagens tecnológicas, que podem ser para as ciências, para produtividade ou lazer. A exploração da tecnologia envolve todas as gerações que são motivadas e exercitam as suas potencialidades mesclando seu uso tanto para o universo acadêmico quanto aos contextos sociais. Se as tecnologias tradicionais já se encontram em plena difusão, cabe ampliar a difusão de como caracterizar e explorar o que a tecnologia pode oferecer sem que haja uma transição divergente e que não necessariamente essa transição signifique uma completa mudança por troca de tecnologias (CARRILLO; MEDINA, 2009).

Carrillo e Medina (2009) listam características das novas tecnologias como: “Armazenamento, Inovação, Novos Códigos e Linguagens, Digitalização, Qualidade Técnica, Interatividade, RCMOS - Revista Científica Multidisciplinar O Saber. ISSN: 2675-9128. DOI 10.51473. São Paulo, v. 03, p. 01-11, mar. 2021. (cc) $\mathrm{EY}-\mathrm{NC}-\mathrm{SA}$ 


\section{Volume 3 - Número 3

Imaterialidade, Diversidade, Automatização, Penetração em todos os setores, centrada em Processos, Instantaneidade, Interconexão" (CARRILLO; MEDINA, 2009, p. 35).

Essas são consideradas as características da atualidade, um tempo que demanda velocidade e volume de informações, construção e trocas de conhecimento como em nenhum outro momento da história. As terminologias tecnológicas se tornaram tão familiares, que muitas vezes são tratadas como parte usual das rotinas cotidianas. Não é novidade nem mesmo para os docentes ou formadores que não dominam tecnologias educativas fazerem usos desses termos e até mesmo fazer uso de algumas ferramentas sem o pleno reconhecimento de que tais máquinas possam ser tidas como intervenções programadas para o uso didático. Dessa forma, surge a conexão da vida social com a educacional.

Nesse sentido, Carrillo e Medina (2009) apontam a possibilidade de integração das novas tecnologias como recurso didático, objeto de estudo, meio de expressão e recursos para organização de um currículo integrado. Apontam que a veiculação do áudio, da imagem e do vídeo somam com o trabalho em um processo que atinge os objetivos educativos.

É um desafio dominar um conhecimento específico de um programa, a linguagem a ser trabalhada e determinar estratégias pedagógicas. Carrillo e Medina (2009) em vasto estudo sobre as tecnologias catalogaram programas que em pouco tempo se tornaram obsoletos pela velocidade da evolução. De tal modo, compreender que a evolução tecnológica faz parte de um processo mais rápido que se possa acompanhar, trata-se de um marco que consolidará a construção de um novo pensamento e uma nova abordagem sobre a qual empregar-se-á as tecnologias.

Ao ser considerado o contexto da linguagem de máquinas e programas eletrônicos, se reconhece que a internet apresenta um conceito inovador para a interação entre sistemas e pessoas. Analisando a complexidade da teia de estímulos e possibilidades da informação e comunicação Carrillo e Medina (2009) corroboram refletindo sobre as práticas de docentes:

Não são poucas às vezes a preocupação da administração e dos professores se centram em como ser justos e atender a tantas e tão complexa diversidade como se pode constar em qualquer aula ou disciplina, e contemplar a pessoa em sua totalidade: interesses, apetências, emoções, inteligências múltiplas, meios, preparação, etc. (CARRILLO; MEDINA, 2009, p. 371).

Os autores ainda apontam que o processo desencadeia, por meio das tecnologias educativas, um princípio didático de aprendizagem que acontece de forma construtiva e colaborativa. Essa dinâmica de aprendizado engloba também uma aprendizagem 


\section{Volume 3 - Número 3

individualizada, auxiliada por agentes externos, por descobrimento quando orientada as atividades a serem alcançadas.

Como recursos a serem explorados na escola Careaga e Videgaray (2009) destacam: páginas web, correio eletrônico ou e-mail, serviços de mensagens instantâneas, fotografia digital, áudio digital, vídeo digital, multimídia (combinação de elementos digitais), processador de textos, planilhas de cálculos, editor de slides, videoconferências, livros eletrônicos, base de dados, programas e linguagens de programação em geral (mapas mentais, estatísticos, simulação e localização, captura de tela), como recursos disponíveis, com acesso pleno, bastando uma página aberta na internet para que isso seja possível.

Careaga e Videgaray (2009), ainda reforçam, que os elementos desencadeiam modalidades de uso educativo como tutoriais (guias informativos), hipertexto e hipermídia (conexões interligados entre textos e outras mídias), programas de exercícios práticos ou entretenimento, simuladores, jogos educativos, ferramentas abertas de aprendizagem (módulos ou portais de ensino manipuláveis), correio eletrônico, bate papo (chat), grupos de trabalho virtuais, provas e testes ou quiz (sistema de perguntas e respostas), aprendizado baseado em internet (com consultas em sites), mapas mentais, práticas de campos virtuais (atividades de internet de forma orientada e programada) e vídeo conferências. Essas modalidades quando incorporadas como estratégias de ensino, podem fomentar, por exemplo, a leitura e a escrita, ou a motivação para a leitura mesmo que para entender enunciados, regras, mas que impulsiona a leitura com sentido.

As adequações didáticas que levarão ao sucesso da abordagem proposta no planejamento, são aspectos importantes a serem observados ao utilizar um programa, nesse sentido se recorre a Romero, Román e LLorente (2009) que elencam as adequações didáticas para utilização de um programa, sendo:

Objetivos de aprendizagem que almeja / Conteúdos de aprendizagem / - Temas que aborda / - Transmissão de valores / - Apresentação de modelos de conduta adequados / - Propõem modelos de resolução de conflitos /Atividades de aprendizagem / Avaliação (estratégias para detectar as aprendizagens adquiridas) / Motivação (como pretende chamar a atenção do usuário) (ROMERO; ROMÁN; LLORENTE, 2009, p. 74).

Além das adequações didáticas é necessário também validar a adequação do programa, de tal modo certificar se o programa pode atender os critérios já validados pela adequação didática. Para assegurar a validez do programa, pode-se observar: "Uso do programa / Facilidade de manejo / -Tempo de resposta à utilização / - Correção de erros / Linguagem / - 


\section{Votume 3 - Número 3

Apresentação de sons, palavras e frases / - Nível de vocabulário / - Utilização de frases: curtas ou longas / - Construções gramaticais corretas / Comentários ou sugestões sobre o software" (ROMERO; ROMÁN; LLORENTE, 2009, p. 75).

Da mesma forma, ao mediar o ensino utilizando a tecnologia é necessário, mesmo quando da não utilização de programas, compreender regras claras para emprego da didática e validez contextual para explorar satisfatoriamente a mediação. Essa mediação direcionada a conteúdos na internet ou em formatos digitais deve ser clara, limpa, estruturada e coordenada. Nesse sentido é importante citar alguns critérios apontados por Almenara (2007):

Vincular o componente técnico ao didático. Não introduzir excessivos "virtualismos" sem uma justificativa didática que podem distrair o aluno da informação chave. Não incorporar recursos desnecessários no material didático. Mais informação não significa mais aprendizagem e em algumas situações o excesso de recursos pode desviar a atenção do aluno dos elementos fundamentais e fazer o material muito extenso ou no caso de materiais em rede, lentos para baixar. Promover um desenho instrucional dinâmico. Ajudar ao aluno na exploração do material de forma que ele permita ter uma visão global por ele mesmo. Propiciar a interação com os conteúdos e com os participantes (professor, aluno, tutor ou administrador do sistema). Não se limita a incorporar materiais (por melhor que sejam), todavia, deve-se oferecer a possibilidade de realizar diferentes simulações, exercícios que facilitem a compreensão e domínio da informação. Realizar materiais que proporcionem a exploração do aluno pela informação e a construção significativa através de recursos próprios (hipertextualidade). Propiciar a conexão e interconexão dos elementos utilizados (texto, sons, imagens, animações, vídeos). Oferecer um entorno flexível para o acesso dos conteúdos, para a eleição da modalidade de aprendizagem e eleição dos meios e sistemas simbólicos com os quais o aluno deseja aprender (envolver a outros elementos de conteúdo, possibilidades de escolha de recursos e organização do processo de aprendizagem segundo suas necessidades) (ALMENARA, 2007a, p. 108-109).

Os espaços educacionais, para cumprir seu papel de formação, devem preparar os sujeitos frente à demanda da sociedade do conhecimento, manipulando equipamentos e a internet, não somente para serviços de entretenimento e comércio, mas, sobretudo para cumprirem com seu papel de cidadãos formados, educados e preparados para cumprir sua função social. Ciente desses desafios, o professor então assume sua responsabilidade de:

Dar informação, estender, clarear, e explicar os conteúdos apresentados. Supervisionar o progresso dos estudantes e revisar as atividades realizadas. Responder aos trabalhos dos estudantes. Assegurar que os alunos estejam alcançando o nível adequado. Formular perguntas para sondar os conhecimentos que expõem os estudantes e descobrir as possíveis inconsistências e erros que vão ter. Elaborar atividades para facilitar a compreensão da informação e sua transferência. Elaborar atividades e situações de aprendizagem de acordo a um diagnóstico prévio. Introduzir o tema de debate e relacioná-los com temas anteriores. Resumir os debates dos grupos realizando inferências. Sanar as possíveis dúvidas das leituras dos materiais didáticos em relação às atividades. Reconhecer individualmente ou em grupo as atividades 


\section{Volume 3 - Número 3

realizadas. Informar e reconhecer os resultados alcançados, etc. (SÁNCHEZ. ESPINOSA, 2007, p.105).

$\mathrm{Na}$ educação mediada por tecnologias se reconhece as capacidades de uma educação midiática que Almenara (2007b), distintamente, resume os seus papeis:

PROFESSOR /Conhecimento técnico do meio / Conhecimento didático /Motivação e pré-disposição/Capacidade de diálogo e negociação / ALUNO/ Motivação /Construção do conhecimento /Desenvolvimento de atitudes comunicativas /Contração da própria realidade / Participação /Cooperação /METODOLOGIA /Ação planejada /Criação de situações propícias /Diálogo / Busca conjunta de soluções /Aprender com os erros (ALMENARA, 2007b, p.95)

Almenara (2007b), se referindo a construção de uma educação midiática, ressalta as possibilidades de utilização do vídeo no ensino-aprendizagem e elenca parâmetros que guiarão os preceitos adequados para sua utilização no processo de ensino-aprendizagem a serem observadas pelo professor ao fazer emprego desta possiblidade como recurso didático:

Podem-se utilizar indefinidas vezes. / Possibilidade de introduzir através da mensagem outros meios como televisão e cinema. / Diminuição progressiva do custo dos equipamentos. /A possibilidade de empregar-se em diferentes níveis educativos. / A facilidade de manejo junto aos equipamentos. /A diversidade de funções que se pode utilizar no ensino. / Favorece um uso ativo ao estudante. / Pode ser facilmente incorporado em um conjunto de materiais multimídia e em rede (ALMENARA, 2007b, p. 131).

Os sujeitos, ao gozarem de uma transição de metodologias equilibradas, constroem funções positivas no processo cognitivo, alcançando diversos fins educativos como, por exemplo, na exploração de um vídeo, se alcança em seus fins: informar, motivar, expressar, avaliar, investigar, ludicidade, expressão estética, recapitular assuntos, suscitar debates, promover atividades, permitir visualização de formas, estruturas e processos, aprendizagem sobre cultura icônica e construção de sua própria identidade, análise de atitudes e valores, referências aos pais, dentre outras. Fins estes que podem corroborar no processo de escrita, no processo de leitura, por fim, no processo de formação.

Uma estrutura combinada de tecnologias sejam elas tradicionais como impressos, ou digitais como smartphones (celulares), podem de igual forma compor um panorama colaborativo, seja através de hiperlinks ou atividades facilitadas em grupos, uma combinação equilibrada dos processos didáticos pode construir uma transição clara e objetiva transpondo segurança ao educador e estímulos adequados ao educando.

Uma educação facilitada por tecnologias está imbuída de caraterísticas como amigável, flexível, personalizada, ativa, dinâmica, pluripessoal, ampliada, multiétnica, colaborativa. Uma 


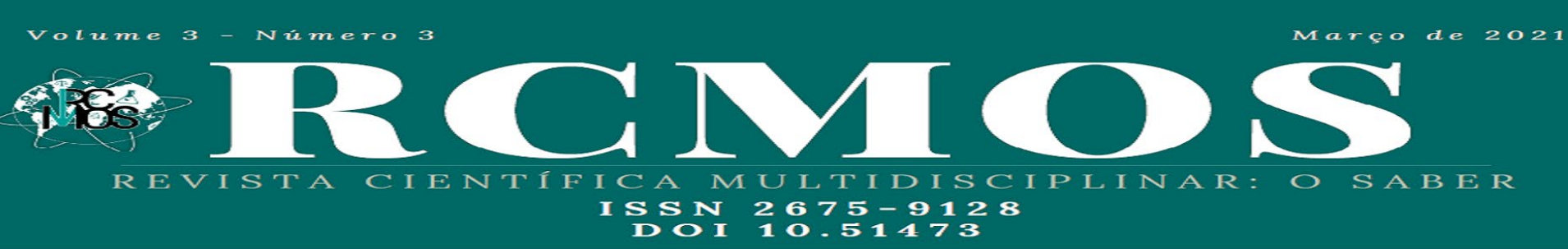

nova educação já está acontecendo. As tecnologias têm contribuído para que essa educação aconteça ao longo dos anos. Os equipamentos eletrônicos trazem destaque por suas especificidades de conexão com a internet e a portabilidade, desta forma a era do novo, a era da transição e a era das "novas" tecnologias, carecem ser percebidas como parte de um processo claro em que o "novo" não cessará, em que a velocidade não reduzirá e em que as estratégias serão sempre atualizadas, reestruturadas, mas sequencialmente consolidadas

\section{Considerações finais}

Ao encerrar as reflexões propostas, conclui-se que a internet exerce forte influência na educação quando a proposta se alicerça nas atividades de leitura e escrita e oportunizam ao estudante acesso à mídia para realizarem as atividades.

Dessa forma as novas formas de estímulo à leitura e escrita no cotidiano dos alunos se dá na percepção equilibrada onde os professores promovem o incentivo de tecnologias indicando materiais em formatos digitais e influenciando positivamente o uso de equipamentos eletrônicos e de materiais em formato digital que sejam explorados por meio dessa tecnologia, que é reconhecidamente parte intrínseca do contexto social dos discentes e este movimento leva a relacionar os equipamentos eletrônicos a uma porta aberta à leitura e à escrita em sua formação, em qualquer ambiente, gerenciando autonomamente seu tempo.

Portanto, os recursos tecnológicos contribuem para o fomento da leitura e da escrita, contudo os métodos tradicionais ainda são bem representativos quanto à motivação para realização de atividades de leitura e escrita relacionadas à formação discente.

\section{Referências}

ALMENARA, J. C. (Org.) Tecnología educativa. España: McGRAW-HILL, 2007a.

ALMENARA, J. C. (Org.) Nuevas tecnologías aplicadas a la educación. España: McGRAW-HILL, 2007b.

CAREAGA, I.O.; VIDEGARAY, M. G. NUEVAS TECNOLOGÍAS Y EDUCACIÓN: Diseño, desarrollo, uso y evaluación de materiales didácticos. México: Trillas, 2009.

CARRILLO, J. A. O.; MEDINA, A. C. (Org.) Nuevas tecnologías para la educación en la era digital. Madri: Pirámide, 2009.

GASCÓN, A. D. L. H.; LABRA, J. P. (org.) Didáctica general: la práctica de la enseñanza en educación infantil, primaria y secundaria. España: McGRAW-HILL, 2008. 


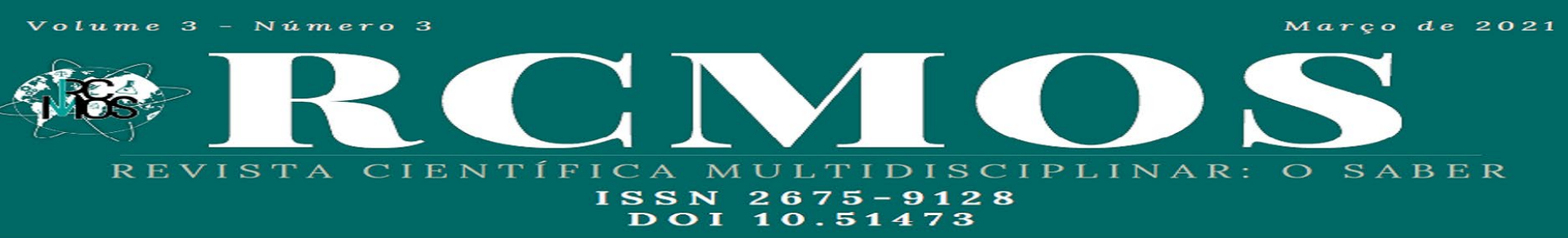

LÉVY, P. As tecnologias da inteligência: o futuro do pensamento na era da informática. São Paulo: Editora 34, 2011.

LIBÂNEO, J. Didática. Coleção Magistério $2^{\circ}$ grau. Série formação do professor. São Paulo: Cortez, 1994.

ROMERO, R.; ROMÁN, P.; LLORENTE, M. D. C. Tecnologías en los entornos de infantil y primaria. España: Síntesis, 2009.

SÁNCHEZ, F. M.; ESPINOSA, M. P. P. (org.) Nuevas tecnologías y educación. Madrid: Pearson Educación, 2007.

SILVA, M. Sala de Aula Interativa. 5. ed. São Paulo: Editora Loyola; 2010.

VYGOTSKY, L. S. Pensamento e linguagem. São Paulo: Martins Fontes, 1993. 108p. 


\title{
REFORMAS DA INTERNACIONALIZAÇÃO DOS CURSOS SUPERIORES NO BRASIL
}

\section{REFORMS OF THE INTERNATIONALIZATION OF HIGHER COURSES IN BRAZIL}

\author{
GERVASIO, Cirlene Ferreira Neri ${ }^{1}$ \\ FONTENELE, Adelaine Aparecida Viana ${ }^{2}$ \\ SOUZA, Allessandra Cândido Ciza de ${ }^{3}$ \\ SOUZA, Ana Maria Reis de ${ }^{4}$
}

\begin{abstract}
Resumo
Objetivos: $O$ presente artigo tem como intuito analisar o cenário gerado pela internacionalização da educação superior bem como os novos papeis atribuídos às universidades no contexto da reforma da educação superior. Metodologia: A pesquisa recorreu ao método qualitativo, onde buscou subsídios em várias fontes publicadas onde foi feita uma breve fundamentação teórica e análise sobre a reforma da educação superior, a concepção da universidade e o seu papel social bem como a internacionalização propriamente dita e as intenções existentes por trás desta. Além disso, evidencia-se os pontos positivos e negativos deste processo dentro do contexto social brasileiro, destacando as melhorias a serem realizadas. Conclusão: enfatizar a necessidade da relação direta entre estratégias acadêmicas e inserção social para que, em processos como estes que envolvem a saída de estudantes para expandir a educação superior brasileira, não se restrinja àqueles que possuem maior renda e, sim, àqueles que de fato estão capacitados a representar o Brasil e intercambiar conhecimentos científicos, experiências culturais e aprendizados sociais.
\end{abstract}

Palavras-chave: Internacionalização. Instituições de Ensino Superior. Reforma educacional.

\section{Abstract}

Objectives: This article aims to analyze the scenario generated by the internationalization of higher education as well as the new roles attributed to universities in the context of higher education reform. Methods: The research used the qualitative method, which sought subsidies from various published sources where a brief theoretical foundation and analysis was made about the reform of higher education, the conception of the university and its social role as well as the internationalization itself and the intentions behind it. Furthermore, the positive and negative points of this process within the Brazilian social context are highlighted, highlighting the improvements to be made. Conclusion: emphasize the need for a direct relationship between academic strategies and social insertion so that, in processes like these that involve students leaving to expand Brazilian higher education, it is not restricted to those who have higher income, but to those who in fact they are able to represent Brazil and exchange scientific knowledge, cultural experiences and social learning.

Keywords: Internationalization. Higher education institutions. Educational reform.

\footnotetext{
${ }^{1}$ Pedagogia UFMG, mestranda Universidad de la Empresa - UDE

2 Pedagogia FISBI, mestranda Universidad de la Empresa - UDE

${ }^{3}$ Pedagogia UERJ, mestranda Universidad de la Empresa - UDE

${ }^{4}$ Pedagogia, mestranda Universidad de la Empresa - UDE

RCMOS - Revista Científica Multidisciplinar O Saber. ISSN: 2675-9128. São Paulo, v. 02, n. 2, p. 01-15, fev. 2021
} 


\section{Introdução}

Por direitos humanos pode-se classificar os direitos e liberdades fundamentais relativos à garantia da vida digna a todas as pessoas, sendo que estes compostos por direitos civis e políticos (CUMPER, 2003). De acordo com a Declaração Universal dos Direitos Humanos (DUDH) da Organização das Nações Unidas (ONU), "Todos os seres humanos nascem livres e iguais em dignidade e em direitos. Dotados de razão e de consciência, devem agir uns para com os outros em espírito de fraternidade."

Segundo Beetham (1998), os direitos humanos são constituintes da democracia, regime político em que os cidadãos elegíveis participam de forma igualitária a partir de atuação direta ou indireta. A efetividade dos direitos e liberdades básicas é conditio sine qua non para que as pessoas possam atuar ativamente frente às demandas públicas sem que haja controle popular por parte dos governantes. Apesar da estreita relação e mútua dependência entre direitos humanos e democracia, esta não se faz de forma simplificada e se mostra carregada de situações onde a violação dos direitos traz limitação à expressão democrática.

Conforme afirmativa de Sguissard (2009), dentre os direitos fundamentais, pode-se citar a educação. Esta é peça constituinte da democracia e possui alto nível de consolidação e expansão dos conceitos atrelados aos direitos humanos, sendo essencial para a permanência da sociedade igualitária, civil e politicamente. A educação é um direito de todos, independentemente de situação financeira, social, local de moradia, dentre outros aspectos.

Diante do pano de fundo da importância da educação para a formação de uma nação, vê-se, ao longo da história brasileira, iniciativas por parte do governo federal no intuito de aprimorar o sistema educacional, principalmente no que tange à formação superior. Dentre essas medidas, ao longo dos anos de 2012 e 2018, pode-se citar a iniciativa por parte do Ministério da Educação, Ministério das Relações Exteriores e Ministério da Ciência, Tecnologia, Inovações e Comunicação na atuação como fomentador do processo de internacionalização da Educação, Ciência e Tecnologia brasileiras por intermédio das Instituições de Ensino Superior (IES) (SAVIANI, 2007).

Audi e Morosini (2010) afirmam que, por meio de programas apoiados pelo governo federal, gerou-se fluidez acadêmica internacional na graduação e na pós-graduação com o intuito do intercâmbio de conhecimentos e pesquisas. Nesse contexto, dá-se grande destaque ao 
Programa Ciência sem Fronteiras, instituído através do Decreto n. ${ }^{\circ} 7.642$ de 13 de dezembro de 2011, responsável pela intensificação do processo de internacionalização do Ensino Superior e configurando este como um fenômeno complexo e peculiar.

Pelo viés acadêmico, os debates sobre o tema demandam, previamente, a compreensão aprofundada sobre o assunto bem como sobre as consequências dos fatos recentes. Assim, com o intuito de estudar as premissas e debater o processo de internacionalização do Ensino Superior brasileiro, o presente artigo traz uma breve discussão sobre a reforma da educação superior, a redefinição do entendimento sobre a Universidade, a internacionalização do ensino superior propriamente dita, as políticas atreladas à internacionalização bem como as implicações geradas por esse processo.

Optar pela pesquisa bibliográfica, para Diascânio (2020, p.98), "É se propor a gerar novos conhecimentos, baseando-se nos processos mentais de análise, síntese, comparação e confrontamentos sobre as teorias existentes, identificando nas bases teóricas existentes as possíveis respostas para o problema científico da investigação".

Constitui-se em um método de pesquisa qualitativa que possibilita o entendimento de diferentes concepções sobre um determinado tema, pensado de forma coletiva num dado contexto e momento histórico (NEVES, 1996). Com esta técnica o pesquisador pode intensificar o acesso às informações sobre determinado fenômeno, seja pela intenção de gerar tantas possibilidades ou pela averiguação de uma ideia em profundidade. Portanto, a pesquisa é de caráter exploratório, e bibliográfico. Segundo Furaste (2006, p.38) a pesquisa exploratória "busca apenas mais informações sobre o que está sendo estudado". "A pesquisa qualitativa sugere a introdução no campo das ciências sociais como mecanismo que intervém sobre o fenômeno em toda a sua instância" (DIASCÂNIO, 2020, p.85).

\section{Fundamentação teórica}

\subsection{Ensino superior}

Conforme Vygotsky, Luria \& Leontiev (1992), o ensino é uma construção de conhecimentos através da participação e da interação com a sociedade. As Instituições de Ensino Superior - IES, segundo as Leis das Diretrizes e Bases de Educação Nacional - LDB 
(Lei n. 9.394/96), tem como finalidade "formar diplomados nas diferentes áreas de conhecimento, aptos para inserção em setores profissionais e para a participação no desenvolvimento da sociedade brasileira e colaborar na sua formação continua", sendo que é por meio dos currículos dos cursos que as IES definem o conjunto de disciplinas, organizando as em uma sequência lógica de conteúdos visando atender as necessidades e expectativas da sociedade em relação ao indivíduo que formam (TCHEOU, 2002).

A exigência de profissionais mais qualificados, por parte das empresas, desloca o eixo da formação, no caso contábil, para a necessidade de novas competências relacionadas com a inovação, a criatividade e a capacidade funcional. Portanto, ocorre uma alteração na estrutura de contratações que passam a requerer trabalhadores com um nível de educação, qualificação e experiência mais elevados.

De acordo com Souza (2006), inúmeras críticas têm sido feitas acerca do perfil dos graduados em contabilidade, gerando movimentos em favor de mudanças, tanto nos currículos como nas técnicas pedagógicas consideradas ultrapassadas, a fim de corrigir as deficiências dos cursos ofertados pelas Instituições de Ensino, possibilitando a formação de profissionais competitivos e competentes.

Sabe-se que o mercado de trabalho está a cada dia mais competitivo, pois a globalização causou uma revolução no campo tecnológico e têm despertado uma preocupação em todas as profissões e, consequentemente, em seus profissionais, surgindo assim à necessidade de investir na formação dos alunos e professores para atuarem nessa nova demanda que a sociedade exige.

Portanto, a formação do profissional no ensino superior passa por muitas etapas que se complementa, não se dissociando a teoria da prática e a orientação com bases pedagógicas, pois as formas de aprendizagem não devem ser esquecidas durante a vida escolar do aluno, não importando a etapa de formação que frequenta.

Outro fator que deve ser valorizado é a atual situação econômica do país, as frequentes oscilações e todo o processo de mudança, pois estabelecem, através do mercado de trabalho, novas exigências e necessidades profissionais de um modo geral. 


\subsection{Reforma da educação superior e redefinição nos fins da universidade}

De acordo com Lima et al. (2008), no Brasil, pode-se notar fortes modificações nas IES, principalmente, entre os anos 2003 e 2010 na gestão Luiz Inácio Lula da Silva em que houve grande proximidade com o movimento global de alteração do ensino superior, através, principalmente, do Processo Bolonha (tradução livre do original Bolong Process) que atingiu diversos países europeus. Esta fase foi marcada por características atinentes às premissas do Processo Bolonha, as quais seguem listadas na Tabela 1.

Tabela 1: Características notadas nas IES.

\begin{tabular}{|c|c|}
\hline ASPECTO GERAL & DESCRIÇÃO \\
\hline $\begin{array}{l}\text { AVALIAÇÃ̈O E } \\
\text { REGULAÇÃAO }\end{array}$ & $\begin{array}{l}\text { Centralidade dos sistemas de avaliação e regulação, que promove maior } \\
\text { rankeamento e a competitividade entre as IES; }\end{array}$ \\
\hline PARCERIAS & Maior incentivo à parceria universidade - setor produtivo; \\
\hline GESTÃO & Adoção de mecanismos de gestão estratégica ou gerencial; \\
\hline \multirow{4}{*}{$\begin{array}{l}\text { ABRANGÊNCIA } \\
\text { SOCIAL }\end{array}$} & Diversificação de cursos e de IES; \\
\hline & $\begin{array}{l}\text { Estabelecimento de metas para ampliar vagas, aumentar a relação } \\
\text { professor-aluno e diminuir o custo-aluno nas universidades públicas federais; }\end{array}$ \\
\hline & Ampliação dos cursos e das vagas mediante educação superior a distância; \\
\hline & $\begin{array}{l}\text { Criação e ampliação de sistemas de concessão de bolsas para estudantes } \\
\text { pobres em IES privadas. }\end{array}$ \\
\hline
\end{tabular}

Fonte: elaborada pelo autor a partir do Bologna Process (2013)

De acordo com Santos (2004), uma das teorias a respeito das alterações lançadas às IES, eram que estas faziam parte de uma série de estratégias para que o Brasil assumisse um posicionamento de destaque internacional quanto à qualidade do ensino universitário, quando comparado a países latino-americanos e africanos.

Assim, a transnacionalização da educação superior passou a corroborar com o avolumamento desse nível educacional tanto regionalmente como globalmente gerando alterações tanto no papel da universidade na sociedade como internamente a estas através da compatibilização curricular com cursos do exterior, destaque institucional, melhoria na metodologia de avaliação e no processo de gestão bem como das redes de pesquisas.

As medidas tomadas ao longo do governo Lula foram consequências diretas daquelas iniciadas pelo Fernando Henrique Cardoso - FHC (1995 - 2002), sendo estas orientadas pelo 
Banco Mundial, através de ações que visavam os seguintes pontos: incentivo à diversidade $\mathrm{e}$ distinção dos cursos superiores; adoção de programas educacionais à distância; diversificação das procedências dos aportes financeiros; implementação de processos de financiamentos de cunho estatal em conformidade com a performance esperada; melhoria e a aproximação entre professor e aluno; combate à saída precoce de alunos; combate às dependências nas disciplinas; exigência a maior transparência quanto aos gastos feitos com dinheiro público; o incentivo às pesquisas na tentativa de alinhar as demandas do mercado com os conteúdo ensinados em sala de aula; a promoção de políticas afirmativas para propiciar um maior acesso dos grupos prioritários; e, por fim, a instituição e o fortalecimento de reduções de mensalidades nas universidades privadas (SANTOS, 2004).

\subsection{Internacionalização do ensino superior}

De acordo com Morisini (2011), é possível destacar três possibilidades geradas pela transnacionalização da educação superior: a dimensionalidade internacional existente desde o século XX, censo está marcada pela incidência desconexa entre os programas; a educação internacional, propriamente dita, elaborada com finalidades políticas; e, por fim, a internacionalização da educação atrelada ao processo de globalização social e econômica, processo gerador de grandes impactos na educação superior.

Pode-se notar ao analisar obras a respeito do tema abordado que, muitos autores usam o conceito de internacionalização para se referir à globalização. Apesar disso, segundo Altbach e Knight (2007), deve-se atentar que estes são conceitos distintos: a globalização está ligada a tendência mundial gerada pelos processos capitalistas, principalmente ao longo do século XXI marcado pelo Estado mínimo e pela conscientização de parte da sociedade sobre a importância da educação superior. Já a internacionalização se refere ao grupo de políticas focados no sistema acadêmicos focadas na transnacionalização deste ambiente fazendo com que este não se limite às paredes da universidade e atinja patamares mundiais.

O Brasil, apesar de ter se inserido no contexto da globalização desde o início de sua história produtiva, aderiu aos ideais da internacionalização, como já citado, apenas na década a partir do Governo FHC, cuja continuidade foi marcada pela atuação intensa do governo federa. 
O Plano Nacional de Educação mais recente, que data o ano de 2014, estabelece dentre suas vinte metas propostas que três correspondam à internacionalização da educação superior:

Meta 12.12) Consolidar e ampliar programas e ações de incentivo à moblidade estudantil e docentes em cursos de graduação e pós graduação, em âmbito nacional e internacional, tendo em bist o enriquecientos da formação de nível superior, (...)

Meta 13.7) Fomentar a formação de consórcios entre IES públicas, com vistas a potencializar a atuação regional, inclusive por meio de plano de desenvolvimento institucional integrado, assegurando maior visibilidade nacional e internacional às aqtividades de ensino, pesquisa e extensão.

Meta 14,9) Consolidar programas, projetos e ações que objetivem a internacionalização da pesquisa e da pós graduação brasileiras. Incentibando a atuação em rede e o fortalecinento de grupos de pesquisa (PNE, 2014)

Diferentemente da globalização, processo contínuo e que não pode ser controle, a internacionalização depende de uma série de fatores que envolvem a decisão dos detentores do poder como consequência de interesses diversos, como por exemplo, a necessidade de melhoria do padrão de qualidade e de confiabilidade atreladas às IES (ALTBACH E KNIGHT, 2007).

\subsection{Implicações da internacionalização do ensino superior}

Oliveira (2000) afirma que a internacionalização do ensino superior pode auxiliar de forma direta a qualificação da mão de obra brasileira, sendo este um dos principais argumentos, por exemplo, da gestão Dilma Rousseff diante o Programa Ciência Sem Fronteiras. A ideia é que o estudante retornaria ao Brasil com uma melhor qualificação para atuar no mercado de trabalho em decorrência de todo o aprendizado adquirido na experiência internacional.

Além disso, pode-se notar no discurso do governo federal, que, além das mudanças focadas nas demandas do mercado, espera-se também uma alteração social em decorrência da possibilidade de aberturas de IES dentro do contexto internacional oferecendo maior visibilidade ao que se produz nas universidades brasileiras bem como propiciando um networking social, acadêmico e profissional. Assim, a troca de conhecimentos culturais e pessoais também seria uma forma de incrementar a hospitalidade brasileira e gerar questionamentos diante dos paradigmas da sociedade (OLIVEIRA, 2000).

Apesar dos aspectos positivos citados, de acordo com Nogueira (2008), a internacionalização do ensino superior deve ser feita através de estratégias que superem a barreira do conhecimento fluente em outra língua. Este é um ponto crucial, já que a educação 
básica brasileira não oferece respaldo suficiente para que um indivíduo adquira fluência e, portanto, os programas de saída do país acabam tendo caráter elitista, assim como o ingresso em universidades públicas.

\section{Considerações finais}

No presente artigo, realizou-se as diversas nuances atinentes às reformas educacionais no ensino superior evidenciando a alteração da concepção sobre a universidade e o impacto na internacionalização das IES. Pode-se concluir que as políticas focadas para este fim, possibilitam a fluidez acadêmica internacional na graduação e na pós-graduação, além de propiciar o intercâmbio de conhecimentos e pesquisas.

Apesar disso, pode-se identificar que o espaço científico muitas vezes é reduzido ao canal onde se evidenciam intenções de cunho político e econômico, sem que haja a percepção correta acerca dos impactos sobre a sociedade. Assim, deve-se enfatizar a necessidade da relação direta entre estratégias acadêmicas e inserção social para que, em processos como estes que envolvem a saída de estudantes para expandir a educação superior brasileira, não se restrinja àqueles que possuem maior renda e, sim, àqueles que de fato estão capacitados a representar o Brasil e intercambiar conhecimentos científicos, experiências culturais e aprendizados sociais.

\section{Referências}

AUDY, J; MOROSINI, M. Inovação, Universidade e Internacionalização: boas práticas na PUCRS. EdiPUCRS: Rio Grande do Sul, 2010.

BEETHAM, D. Human rights as a model for cosmopolitan democracy. In: ARCHIBUGI, D.; HELD, D.; KOHLER, M. (Eds.). Re-imagining political community: studies in cosmopolitan democracy. Cambridge: Polity Press, 1998.

\section{BOLOGNA PROCESS. EUROPEAN HIGHER EDUCATION AREA. Ministerial}

Declarations and Communiqués. Apresenta documentos sobre o Espaço Europeu de Ensino Superior. Disponível em: http://www.ehea.info/article-details.aspx?ArticleId=80. Acesso em: 25 fev. 2021. 
CUMPER, P. Direitos humanos: a história, desenvolvimento e classificação. In: HEGARTHY, A.; LEONARD, S. Direitos humanos. Uma agenda para o século XXI. Lisboa: Instituto Piaget, p. 21-34, 2003.

DIASCÂNIO, J. M. Etapas da pesquisa cientifica. Rio de Janeiro: Autobiografia, 2020.

FURASTÉ, P. A. Normas técnicas para trabalho cientifico: elaboração e formatação. 14. ed. ampl. e atual. Porto Alegre: [S. n.], 2006.

NEVES, J. L. Pesquisa qualitativa - características, uso e possibilidades. Cadernos de pesquisa em administração, São Paulo. v. 1, n. 3, 2. sem. 1996.

NOGUEIRA, M. A.; AGUIAR, A. M. S.; RAMOS, V. C. C. Fronteiras desafiadas: a internacionalização das experiências escolares. Educação e Sociedade. Campinas, v. 29, n. 103, p. 355-76, mai./ago. 2008.

OLIVEIRA, J. F. A reestruturação da educação superior no Brasil no processo de Nuances: estudos sobre Educação. Ano XVII, v. 17, n. 18, p. 50-67, jan./dez. 2010. Metamorfose das universidades federais: o caso da UFG. 2000. Tese (Doutorado em Educação). Faculdade de Educação, Universidade de São Paulo, São Paulo, 2000.

PORTUGAL. Ministério da Ciência, Tecnologia e Ensino Superior. Processo de Bolonha. Disponível em: https://ec.europa.eu/education/policies/higher-education/bologna-process-andeuropean-higher-education-area_pt. Acesso em: 11 jan. 2020.

PORTUGAL. Lei Federal 13.005, de 25 de junho de 2014. Aprova o Plano Nacional de Educação - PNE e dá outras providências. Brasília, DF, 25. jun. 2014.

LIMA, L.; AZEVEDO, M. L. N.; CATANI, A. M. O processo de Bolonha, a avaliação da educação superior e algumas considerações sobre a universidade nova. Avaliação, Campinas; Sorocaba, v. 13, n. 1, p. 7-36, mar. 2008. Disponível em: https://ape.unesp.br/pdi/execucao/artigos/avaliacao/a02v13n1.pdf. Acesso em: 07 ago. 2020.

SANTOS, B. S. A universidade no século XXI: para uma reforma democrática e emancipatória da universidade. São Paulo: Cortez, 2004.

SAVIANI, D. História das ideias pedagógicas no Brasil: Campinas: Autores Associados, 2007.

SGUISSARD, V. Universidade brasileira no século XX. São Paulo: Cortez, 2009.

SOUZA, M. B.; ORTIZ, H. C. A estrutura básica para o ensino superior de contabilidade. São Paulo: Saraiva, 2006. 
TCHEOU, Hellen. Avaliação do ensino de Contabilidade nos Cursos de Administração de Empresas na cidade de São Paulo. Dissertação (Mestrado). Centro Universitário Álvares Penteado, São Paulo, 2002.

VYGOTSKY, L. S., LURIA, A. R. LEONTIEV, A. N. Linguagem, desenvolvimento e aprendizagem. São Paulo: Ícone, 1992. 


\title{
A INTRODUÇÃO DA EDUCAÇÃO ESCOLAR INDÍGENA NA RESERVA INDÍGENA DE CAARAPÓ-MS: REFLEXÕES DE UM ASPIRANTE A XAMÃ ${ }^{1}$
}

\section{THE INTRODUCTION OF INDIGENOUS SCHOOL EDUCATION IN THE INDIGENOUS RESERVE OF CAARAPÓ-MS: REFLECTIONS OF AN ASPIRANT TO THE SHAMAN}

\author{
MARTINS, Elemir Soares ${ }^{2}$ \\ SILVA FILHO, Eduardo Gomes da ${ }^{3}$
}

\section{Resumo}

Neste artigo, propõe-se discutir o processo de introdução da Educação Escolar Indígena na Aldeia Caarapó-MS, a partir das vivências e experiências dos próprios índios, em particular, destaca-se a trajetória do indígena Elemir Soare Martins, que retrata em sua Dissertação de Mestrado, a ser defendida no Programa de Pós-Graduação em História da Universidade Federal da Grande Dourados-MS, as nuances da introdução do processo educacional do povo Guarani e Kaiowá, perpassando além desta trajetória, outras variantes deste processo, como nos casos das ações das Igrejas Evangélicas e alianças institucionais que foram realizadas com ONGs e Universidades.

Palavras-chave: Educação. Reserva Indígena. Xamã.

\begin{abstract}
In this article, it is proposed to discuss the process of introducing Indigenous School Education in Aldeia Caarapó-MS, based on the experiences and experiences of the Indians themselves, in particular, the trajectory of the indigenous Elemir Soare Martins, which he portrays in his Dissertation, stands out. Masters, to be defended in the Post-Graduate Program in History of the Federal University of Grande Dourados-MS, the nuances of the introduction of the educational process of the Guarani and Kaiowá people, going beyond this trajectory, other variants of this process, as in the cases of actions of Evangelical Churches and institutional alliances that were carried out with NGOs and Universities.
\end{abstract}

Keywords: Education. Indigenous Reserve. Shaman.

\footnotetext{
${ }^{1}$ Esse texto é uma adaptação de parte da minha Dissertação de Mestrado, orientada pelo Prof. Dr. Levi Marques Pereira, PPGH/UFGD.

${ }^{2}$ Mestrando - Programa de Pós-Graduação em História - Universidade Federal da Grande Dourados - MS, PPGH/UFGD - Brasil. Bolsista CAPES. E-mail: elemirs.martinsufgd@gmail.com

${ }^{3}$ Professor da Universidade Federal de Roraima - UFRR. E-mail: eduardo.filho@ufrr.br

RCMOS - Revista Científica Multidisciplinar O Saber. ISSN: 2675-9128. São Paulo, v. 02, p. 01-15, fev. 2021.
} 
Introdução

Sou ava (indígena) da etnia Guarani Nhandeva/Kaiowá, pertenço a parentela Escobar, Martins, Vera, Soares. Nasci numa reserva indígena onde, desde 1924, os meus parentes indígenas construíram várias formas de resistências e de sobrevivências. É um tekoha que espera por elementos tradicionais essenciais ${ }^{4}$ para poder continuar descortinando características negativas impostas pela colonização, chama-se Reserva Indígena de Caarapó. Pertenço a uma família que, ao longo desses anos, os membros preferiram aderir ao evangelho e, ao mesmo tempo, continuar adquirindo saberes ancestrais e com eles superar vários problemas históricos e, acima de tudo, sentindo a luz do protagonismo caminhando junto deles. Como muitas parentelas, a família na qual pertenço passou várias adversidades, advindas do processo de colonização e de várias tentativas de dizimação dos povos nativos. Vivenciaram várias transformações que ocorreram nessa reserva, onde os chefes atuavam em diferentes momentos, nos quais se incluíam várias temporalidades.

A sociedade caarapoense, que não tem muito conhecimento sobre a Reserva Indígena de Caarapó, entende que ela foi criada para resolver os problemas dos índios e, por conseguinte, torná-los "obedientes" e "civilizados e trabalhadores". Coloco entre aspa esses dois conceitos pois, na prática, ou seja, dentro da aldeia, a comunidade se organizou, buscou a sobrevivência em constante negociação com algumas instituições, entra as quais estavam: Missão Caiuá, CIMI, FUNAI, Escola e Igrejas Evangélicas Pentecostais.

Como explanado acima, mesmo sendo breve, a sociedade branca (karai) de Caarapó, imaginam essa área como único "lugar de índio"; onde as duas etnias Guarani e Kaiowá podem viver adequadamente, como no paraíso escrito na Bíblia Sagrada. Acharam várias justificativas para nos colocar como povos inferiores em nosso próprio território, não queriam saber nada sobre a cultura indígena, tampouco nos enxergar como gente.

Vivemos as histórias narradas pelos brancos, nas quais as imagens de indígenas aparecem nos livros didáticos, como selvagens, língua ignóbil, pelados, como indivíduos incapazes etc. Todas essas histórias transcorridas pela sociedade ocidental reiteraram injustiças em relação aos nativos.

\footnotetext{
${ }^{4}$ Segundo o que eu consegui entender, da conversa que tive com liderança da retomada, senhor Nardo, os elementos são: o fortalecimento de saberes indígenas, língua materna, escola diferenciada de qualidade, a valorização e o fortalecimento dos papeis dos rezadores e das rezadoras da aldeia. As construções de casas de rezas (óga pysys) e, por fim fortificar o diálogo sobre a intolerância religiosa.
} 


\section{Fundamentação teórica}

\subsection{O lugar de onde falo: memórias, conflitos e resistência}

O atual Estado de Mato Grosso do Sul tem a segunda maior concentração do povo indígena do Brasil, cuja maioria é da etnia Guarani e Kaiowá. Dos mais de 65 mil indivíduos dessa etnia que vivem hoje no Brasil, cerca de 30 mil residem no Sul desse Estado. Esse grupo é subdivido em três subgrupos, sendo o Guarani (Ñandeva), Kaiowá (Paï-Tavyterã) e Mbya, todos pertencentes à família linguística Tupi-guarani (PIMENTEL, 2012).

Os Guarani e Kaiowá da Reserva Indígena de Caarapó não querem mais se isolar da sociedade caarapoense, para que isso seja possível, segundo esses rezadores desse local, acionam os conhecimentos ancestrais e, para os líderes pentecostais indígenas também informação do arcabouço religioso ocidental, para entender, planejar, consertar o seu mundo e a sua realidade.

Muitos desses conhecimentos tradicionais ganharam prestígios e ressignificações, porque os ajudaram a sobreviver no meio da violência e dos ataques por ser "diferente", nem por isso, esses deixaram de ser índios numa reserva. É importante ressaltar que esse povo não tinha voz e nem mesmo apoio por parte do órgão do Estado, para manter suas práticas tradicionais e planejarem seu futuro. Várias parentelas foram colocadas numa área para atender as expectativas do Estado brasileiro, ou seja, de torná-los brancos, assim, para exercerem os trabalhos que os "verdadeiros brancos" não exercem como, por exemplo, cortar cana, derrubar mata, colher maçã, catação de milho, arrancar feijão etc.

As mulheres indígenas também não ficavam de fora dessa atividade exploradora, elas colhiam muito algodão pela redondeza da reserva, frequentava também boia-fria, onde arrancava feijão para sustentar seus filhos e família. Enfim, esperava-se que este povo desaparecesse de vez como povos diferentes.

Entretanto, as mudanças ocorreram, ao contrário do que se esperava, porque esse povo percebeu várias alternativas para continuar resistindo como indígena, mesmo sofrendo várias influências da cultura dominante.

As pesquisas do historiador Antonio Brand (1993, 1997 e 2004) facilitam a compreensão a respeito do tema. Retomo a discussão para mostrar como os indígenas resistiram e continuam criando novas alternativas para sua sobrevivência. Quero mostrar também, a partir das pesquisas já feitas, que os coletivos se adaptaram à reserva e continuaram renovando suas 
estratégias de resistências. As escolhas de autores ocorreram na medida em que fiz as leituras. A título de relevância da pesquisa, Brand, por exemplo, é o autor mais citado na atualidade, porque o mesmo apresenta dados muito relevantes sobre as populações indígenas do MS. Por esse motivo, me ative em maior perspectiva na leitura dos textos desse importante autor para embasar o trabalho.

As populações indígenas, que permaneceram até os dias atuais resistindo, se reorganizando em constante negociação, mesmo tendo sido negados pela historiografia mais tradicional elitista, lembram-se muito bem dos seus tekoha guasu (território ou território amplo) ocupados por eles há séculos, situados entre o rio Apa, serra de Maracaju, rio Brilhante, rio Ivinhema, rio Paraná, rio Iguatemi e fronteira com o Paraguai, no atual Estado de Mato Grosso Sul (VIETTA, 2007).

Nesse tekoha guasu, agrupavam-se, especialmente em áreas de ka'aguy guasu (mata fechada) e ao longo dos ysyry (córregos) e ysyry guasu (rios), em pequeno grupo de parentela, integrados por uma, duas ou mais te'yi tuicha (famílias extensas), que cultivavam entre si inúmeras relações de casamento. As lideranças de família eram tekoharuvicha (chefes do tekoha) ou ñanderu (nosso pai-mestre). As lideranças daquela época apoiavam-se em suas experiências, seus prestígios e nas atribuições das esferas política e religiosa.

$\mathrm{Na}$ época em que foram instituídas pelo Serviço de Proteção aos Índios (SPI $)^{5}$ as reservas indígenas no atual Estado de Mato Grosso do Sul, os Guarani e Kaiowá passaram a sofrer um processo de redução de seus territórios tradicionais. O órgão oficial, segundo Benites (2014), desconhecendo o modo de viver dos Guarani e Kaiowá, e o modo de ocupar os seus tekoha guasu (seus territórios), instituiu entre 1915 e 1928 oito minúsculas Reservas: Jagua Piru e Bororo em Dourados (Francisco Horta Barbosa), Reserva indígena de Caarapó em Caarapó (José Bonifácio), Guapo’y em Amambaí (Benjamim Constat) e Limão Verde em Amambaí, Pirajui em Paranhos, Ramada ou Sassoro em Tacuru, Taqueperi em Coronel Sapucaia, Jakare'y ou Porto Lindo. A área máxima prevista era de 3.600 hectares, na maioria dos casos, a área demarcada foi ainda menor (BRAND, 1993; 1997).

$\mathrm{Na}$ imagem abaixo, podemos observar um mapa, onde estão localizadas as referidas reservas indígenas criadas na época do Serviço de Proteção ao Índio-SPI. A criação dessas reservas são, portanto, reflexo de política antiindígena que se estabeleceu e se fortificou por aqui. Por meio das pesquisas e estudos, se conheceram a situação dos Guarani e Kaiowá de MS. Essas áreas reservadas para os Guarani e Kaiowá “territorializaria os indígenas, obrigando-os a

${ }^{5}$ Em 20 de junho de 1910, pelo Decreto lei n ${ }^{\circ}$ 8.072, foi criado o Serviço de Proteção aos Índios (SPI). RCMOS - Revista Científica Multidisciplinar O Saber. ISSN: 2675-9128. São Paulo, v. 02, p. 01-15, fev. 2021. 
residir em espaços restritos, com fronteiras fixas. Tal processo, obviamente tinha como corolário a liberação de terras para a colonização da região" (SILVA, 2007, p. 46).

Mapa 1. Reservas Indígenas criadas pelo SPI em MS.

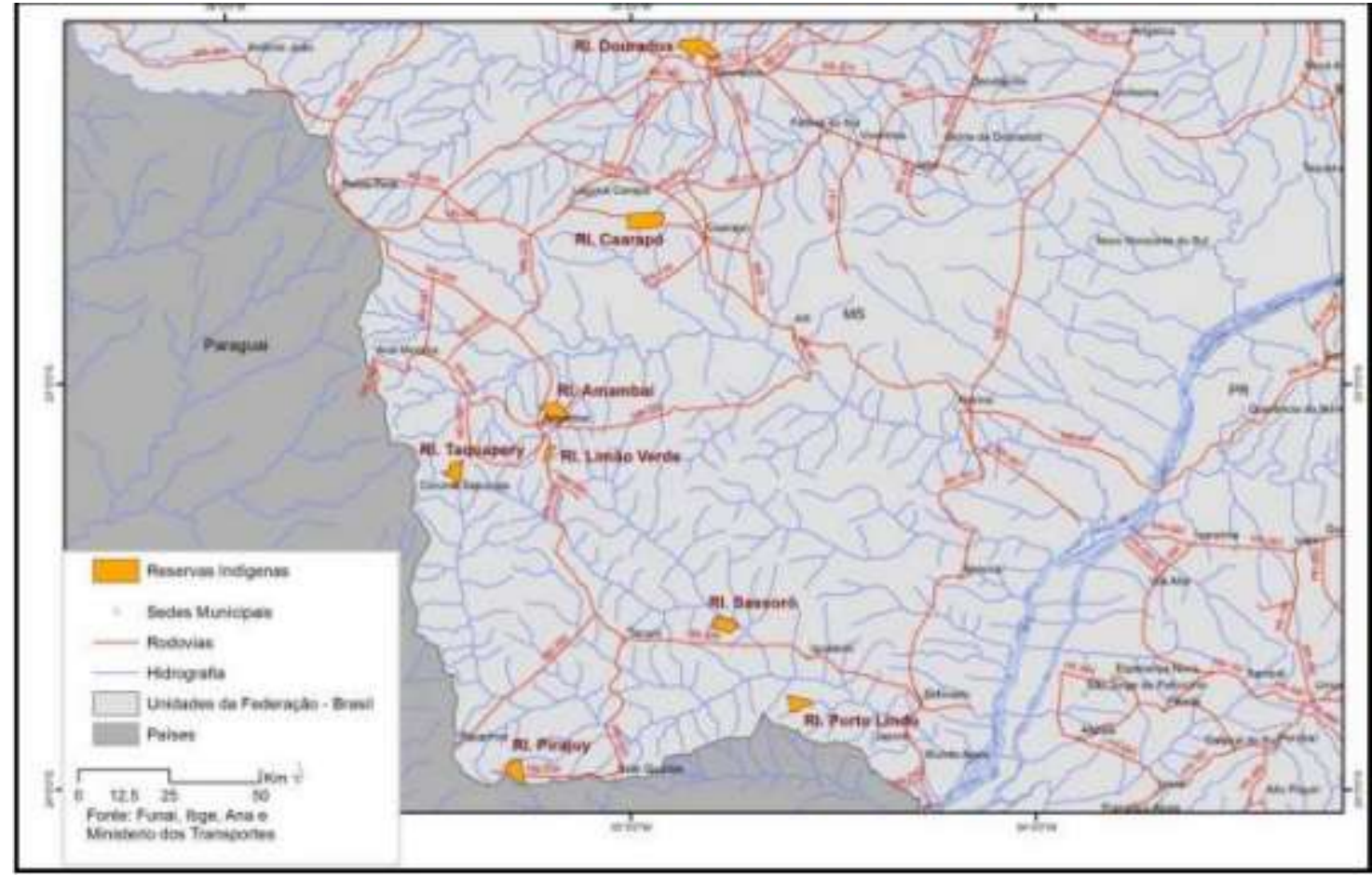

Fonte: (MORAIS 2016, p. 48).

Os colonos da sociedade ocidental não conseguiram entender ainda a vida do povo indígena, porque, desde que expulsaram este do seu território, ensaiavam roubar-lhes a memória, a história, a língua, a religião, por fim, o ava reko (jeito de ser indígena). Os karai "chegaram por aqui e não demonstravam nenhum tipo de respeito e muito menos nos enxergavam como gente", me disse uma rezadora da Te'ýikue. Para eles, escravizando, aniquilando a religião indígena, destruindo a natureza, impondo a língua, destruindo a vida e, por fim, dando trabalho desprezível, uma minúscula área que não ofereceria sobrevivência já era uma atitude "humana".

Contudo, várias formas de organização e resistência podem ser observadas ao longo do tempo na tekoha Guarani e Kaiowá. Uma das principais, trata-se da educação, inicialmente a parentela mais jovem foi alfabetizada em língua materna, posteriormente, com o avanço das religiões pentecostais nas aldeias a coisa mudou de figura, veremos isso a seguir. 
2.2 Memórias do início da Educação Escolar Indígena na Aldeia Caarapó-MS: um breve resumo autobiográfico de um aspirante ao xamanismo

Iniciei a minha vida de estudante após seis anos, até porque nessa época os pais não mandavam seus filhos à escola tão cedo, pois fazia parte do ñeñangareko (de cuidar da infância das crianças). Não tão diferente das demais crianças guaranis, vivi transitando nos dois mundos religiosos, ao mesmo tempo em que eu frequentava culto, por outro lado ouvia sempre os cantos ao longo da noite. Vi algumas crianças da mesma idade que eu enfrentando a mesma epidemia que eu havia enfrentado, os pais dessas crianças chegavam à igreja desesperados, mas com esperança de buscar cura para tais doenças. Os crentes sempre demonstraram dedicações com os recém-chegados na igreja.

Eu não entendia muito bem o que estava acontecendo com a minha cultura. Sem que soubéssemos, o homem branco já havia destruído o nosso território. Quiseram me dar uma cultura que me deixaria mais pobre espiritualmente. O momento em que me reconheci, de novo, foi na época em que comecei a frequentar a escola indígena e me aproximar de novo dos mais idosos, sobretudo dos rezadores.

A escola foi construída de sapê denominado por nós indígenas de óga kapi’i (casa de sapê). Essa escola além de oferecer espaço não tão diferente da realidade do aluno também ofertava uma educação escolar diferenciada. Conforme o professor Alécio: "A gente buscava trabalhar diferenciado com os alunos, aliás, a própria escola refletia isso nos alunos, onde eles chegavam sem medo, com pezinhos empoeirados, roupas humildes e nós professores indígenas os recebendo bem para que se sintam acolhidos"6. Nessa sala cabiam 15 ou no máximo 20 alunos. Atrás da sala foi instalada provisoriamente cozinha onde os alunos lanchavam.

\footnotetext{
As aulas começaram embaixo da casa de sape. Foi construída entre 1997- 1998, onde muitas pessoas da região Mbokaja fizeram mutirão (pucherõ - trabalho coletivo) para levantar escola. Foi meio difícil no início, segundo a minha observação, até porque esperamos alguns anos para termos escola de tijolo, outro problema que enfrentamos em relação a construção da escola foi parte de alguns parentes que não aceitavam muito, pois falavam que a escola ficaria apenas pra família da região. Mas aos poucos eles mais ou menos aceitaram. Então, a escola Mbokaja é visto ainda até hoje como se fosse só da família, porém não bem assim, porque aqui tem alunos das duas etnias tanto Guarani e Kaiowá e, assim fomos fortalecendo a nossa identidade e mostrando o quanto nossa etnia é importante para o coletivo maior, sobretudo para quebrar o paradigma em relação aos Guarani Nhandéva do Mbokaja. Vejo que precisamos trabalhar mais a nossa cultura, investir mais nisso. Começando pela presença contínua dos rezadores na escola e no espaço, para que os alunos se sintam à vontade em interagir com eles e aprender (Professor Guarani Crispim Soares Martins, 2020).
}

${ }^{6}$ Professor na Aldeia indígena Caarapó-MS, s/d. 
$\mathrm{Na}$ imagem a seguir pode se observar melhor a estrutura do interior da sala de aula.

Imagem 1: Primeira escola da região Mbokaja feita de sapé

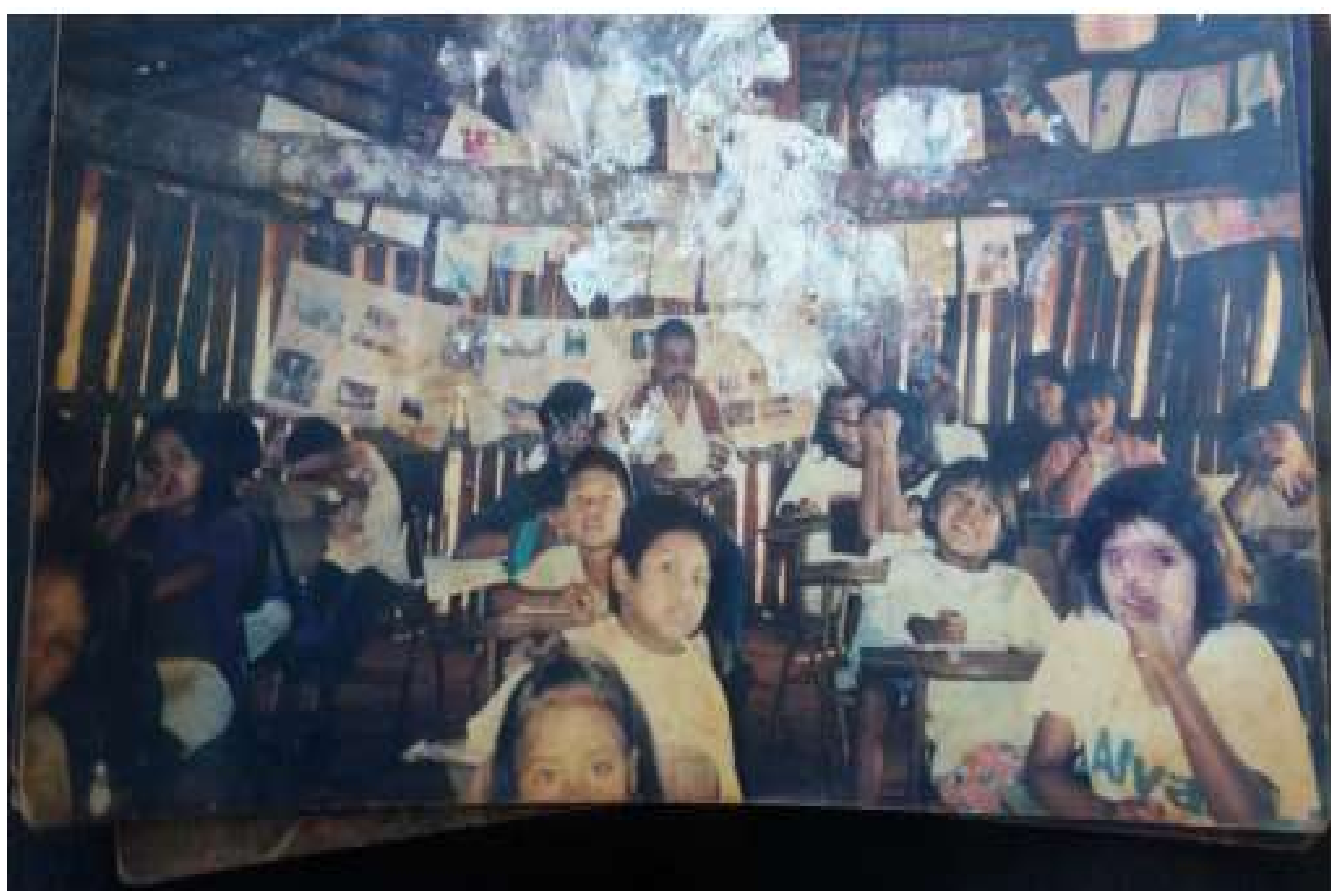

Fonte: Alécio Soares Martins

O primeiro professor que tive foi Alécio Soares Martins, o qual me alfabetizou na minha língua guarani, embaixo de uma escola de sapé, onde aprendi a ler e a escrever como ava (indígena). Como meu pai era da igreja pentecostal, não almejou que eu frequentasse a escola da Missão, também por causa da distância e para não sofrer por ser de uma família pentecostal.

Fui alfabetizado na língua materna guarani. As primeiras palavras que consegui pronunciar foram: yvy, ysyry, ygua, yvyra, ysy, ama, ava, avati, etc., o professor trabalhava com os nomes dos animais, das plantas, dos rios, do nosso cotidiano. Não trabalhavam as vogais em sequências, pois, como indígena, gosto muito da vogal "y", nesse caso, eu tentava sempre me lembrar das palavras que são pronunciadas no dia a dia das pessoas, até porque são palavras que os espíritos deram.

Ser de uma família pentecostal requer resistência também, pois algumas famílias que foram consideradas pelos crentes indígenas de "católicos", zombavam, imitavam a oração só para nos intimidar. Para mim, foi um pouco difícil, porque eu não conseguia entender bem o que estava acontecendo. Na escola, as crianças da mesma idade que eu, riam muito do meu cabelo, do meu estilo, sobre o qual a minha mãe fazia questão de me diferenciar como filho de crente. Antes de ir à escola, os meus pais já conversavam comigo, proibiam-me de jogar futebol, me orientavam para ser um exemplo de criança no molde pentecostal. Entretanto, sempre que RCMOS - Revista Científica Multidisciplinar O Saber. ISSN: 2675-9128. São Paulo, v. 02, p. 01-15, fev. 2021. 
surgia oportunidade para jogar com os colegas, eu aproveitava. Como a escola ficava perto de nossa casa, optaram em me colocar nela, pois para eles eu não teria muitos problemas relacionados às coisas descritas.

Além do ensino religioso que meus pais me passavam, através do kokue (roça) me ensinavam também sobre o teko porã (o bem viver indígena), onde eu pudesse priorizar a reciprocidade e o respeito pela natureza. Certo dia, eu estava meio emburrado com meu pai, e ele queria me levar para carpir com ele, mas como eu estava com esse comportamento, não podia, pois, a plantação de arroz é bem delicada, por isso possibilitaria ao mau agouro ter sentido. Assim, eu fui aprendendo e fortalecendo o conhecimento sobre os cuidados na perspectiva indígena.

Portanto, a minha vida adulta iniciou cedo, na roça, onde me passaram e me ensinaram as práticas coletivas de importância dos princípios guarani, sendo um lugar de educação indígena e de vivendi indígena, onde os laços das famílias são fortalecidos também. Na carpida e hora do tereré, conversávamos sobre a história dos mais velhos, dos parentes que faziam parte da formação do lugar, sobre os preceitos culturais. Enquanto isso a minha mãe fazia colheita de milho e dos demais alimentos que havíamos plantado e me explicava sobre as sementes etc. Nossa família tinha duas roças, sendo que uma ficava perto da nossa casa e outra ficava não tão longe.

Aos poucos, essa atividade tradicional foi enfraquecendo no meio da minha família, porque o meu pai saía muito para evangelizar nas demais aldeias e para trabalhar na usina, e a minha mãe tinha uma irmã para cuidar, porque a mesma tinha necessidade especial, situação que transformou muita coisa.

Enquanto o meu pai saía para trabalhar, a minha mãe ficava sobrecarregada de responsabilidade, ao mesmo tempo em que se preocupava com a nossa educação, também se preocupava em cuidar da igreja. Isso exigiu dela resistência. Por outro lado, ela conseguiu equilibrar sua responsabilidade, porque alguns fiéis a ajudavam.

Mesmo com dificuldade, minha mãe sempre me mandava para a escola. Na terceira série estudei com Lídio Cavanha Ramires, um professor que sempre focava a questão da cultura indígena, falava para nós sobre nossas artes, rezas, aldeias, rios, pesca, conto, poesia, entre outros assuntos. Isso despertava interesse em conhecer mais, aprender de novo, reavivar dentro de mim a minha espiritualidade indígena e a minha cultura.

$\mathrm{Na}$ medida em que a escola indígena estava se firmando na Reserva Indígena de Caarapó, por outro lado houve resistência por parte dos crentes indígenas para não reavivar a 
cultura indígena, por exemplo, na minha família não se falava muito das histórias indígenas Guarani e Kaiowá, raramente se conversava sobre isso. Meu pai falava que só assim poderíamos ser abençoados por Deus, igualmente receber dom de curar, dom de revelação, dom de avivamento, dom de cantar, dom para tocar instrumento, dom para liderar. Uns do dom mais almejado nessa época, foi dom de curar, dom de expulsar demônio e de revelar, principalmente pelos líderes da igreja (dirigente da igreja); ficavam horas e horas fazendo oração, jejum e frequentando "monte".

Por isso, muitas vezes, pediam-se para apagar alguns saberes e habilidades tradicionais adquiridas do xamã da parentela. Uma das pessoas que me ensinou e aperfeiçoou o meu conhecimento foi a Lauriana Escobar, que sempre falava dos seus antepassados, das rezas, dos principais rezadores que se destacavam pela região. Ao mesmo tempo em que sofríamos com a doutrina da igreja, sempre conseguíamos aprender sobre a nossa cultura. Havia dias que ela levava punição pelo dirigente indígena, mas sabia da importância de passar o conhecimento para nós. A punição tinha várias formas, algumas delas que destaco são: pegar banco por um mês ou mais sem ter direito de cantar, contar testemunho e frequentar culto todos os dias; não tomar santa ceia e por fim, depende também das regras de cada dirigente da igreja, até porque ele que determina as regras.

Mesmo fazendo parte do grupo pentecostal, os anciões e anciãs sempre buscavam narrar aos netos sobre as histórias indígenas, incluem-se aí sobre a caça, sobre a armadilha para pegar os animais silvestres comestíveis, plantas medicinais, sobre os cuidados que as crianças devem ter com animais que trazem notícias ruins (guyra mbora'u, mymba mbora'u) etc.

Apesar de não ter muita habilidade em estudo, fui aluno esforçado, porque eu conseguia fazer as minhas tarefas. No primeiro momento, sofri muito para ler, ao mesmo tempo para escrever. Na minha casa, eu tinha muitos afazeres, então, não fui incentivado para olhar o meu caderno, sempre nos preocupava em trabalhar para não passarmos dificuldades. Entretanto, mesmo assim, eu conseguia ler e me esforçar para passar de ano.

Lembro-me da primeira vez que consegui escrever duas linhas de frases sobre árvores, nas quais enfatizei a importância para mim, como naquela não tinha muitos cartazes sobre alfabeto e vogais na minha língua, foi difícil decifrá-los, parecia-me que era impossível chegar ao nível que o professor esperava. Por outro lado, tinha outro tipo de ensinamento que eu precisava seguir, os meus pensamentos eram limitados sobre o meu mundo. O meu movimento

\footnotetext{
${ }^{7}$ É um lugar que fica isolado, geralmente no mato, onde segundo pastor Cornélio, se busca a presença de Deus com mais liberdade e pedir ajuda, onde há momento de se confessar, pedir perdão e pedir dons espirituais. 
foi de escola para casa e igreja. Todos os dias participava do culto. Destacando sobre o pensamento limitado e o espaço limitado que me colocava, foi para eu regar o meu medo com a ignorância, absolutismo sendo mais para destruir meu caminho indígena; posto isto, busco perceber essas regras familiar e das igrejas pentecostais como movimentos de tornar-se um indivíduo ao ore evangelho (sendo o único e não podendo receber os que não pertencem a eles), ou seja, não pertencentes ao grupo dos crentes pentecostais.

Além da minha avó, só o professor passava alguma coisa relacionada à cultura indígena. Como o processo da educação escolar indígena estava em construção nessa aldeia, a comunidade ficava dividida entre os saberes tradicionais e saberes dos brancos (karai), até porque a igreja influenciava nessa questão. Sobre isso, Virginio Soares comenta da seguinte maneira:

A gente não queria ser diminuído por sermos crentes, tentávamos ser respeitados aqui na aldeia e lá fora, pra isso precisávamos que os nossos fillhos aprendessem também a língua dos brancos. Eu sabia que a igreja conseguiria despertar muita coisa boa nas pessoas (Virginio Soares s/d).

Conforme a fala desse meu interlocutor, fica claro também o empenho dos fiéis indígenas em romper a exclusão dos indígenas da sociedade não-indígena e da Reserva, para isso, cobravam os professores o ensino da Língua Portuguesa desde a alfabetização. Conforme a análise de Soares, por meio da Igreja as pessoas conheceram mais a realidade e para cobrar os seus direitos. Essa problemática perdurou até 2005, pois se aceitava mais o ensino da Língua Guarani, com exceção de outras práticas culturais.

Quando os pais pentecostais descobriam que os filhos estavam sendo influenciados pelos professores a aprenderem as rezas, danças, logo tiravam da escola ou proibiam os filhos de participar dessas atividades escolares, nas quais se incluía também a Educação Física.

Faziam questão que os seus filhos e alunos se vestissem com camisa social, calça social para os professores não os obrigar a participarem das atividades ditas culturais, que passaram a fazer parte do currículo da escola indígena. Nessa situação, os professores buscavam resolver na base do diálogo com os pais, explicando-os da importância dos filhos de interagirem com o mundo escolar, principalmente no que tange às práticas culturais.

Assim cheguei na quarta série com o professor Alécio, momento em que ele viu em mim empenho, sendo assim me aplicou uma prova para passar para a quinta série. Com esforço, consegui ser aprovado e cheguei à escola Ñandejara, hoje localizada no centro da aldeia. Portanto, os meus professores das séries iniciais foram Alécio, Ladio e Lidio. Na quinta série foi mais difícil, já que a maioria dos professores eram da cidade. Nessa época, o meu português 
estava abaixo dos demais da turma. Ficava no canto da sala para não ser questionado, esse tipo de comportamento adquiri na igreja, porque na igreja as crianças sentavam no canto, e não podiam falar, brincar, só podiam ir ao banheiro e beber água, na maioria das vezes o obreiro ficava responsável por elas. Na hora da pregação, ficávamos assistindo o pregador falar. Por isso, talvez, o meu comportamento foi diferente na turma. Sendo assim, me esforcei bastante para ler na outra língua, ficava horas e horas lendo a Bíblia dos meus pais, porque nessa época, não fui autorizado para pegar livro da escola. Lembro-me da primeira vez que li sobre o nascimento do mundo, no livro de gênesis. Copiava as palavras no meu caderno para pronunciálas.

Assim, conseguia aprender as palavras novas e ouvindo os colegas falar, por exemplo, para pedir licença, na hora de agradecer, aliás, a professora da língua portuguesa fazia questão de nos ensinar cada palavra para esquecermos da nossa. Todavia, através da estratégia indígena, sabendo transitar nessas duas realidades distintas, consegui superar alguns obstáculos, conseguindo ler na língua dos brancos e, ao mesmo tempo, não me esquecendo da minha língua mãe.

\subsection{O Início da Trajetória Acadêmica}

Antes mesmo de concluir o Ensino Médio, me interessei muito em estudar o fenômeno da entrada e da expansão das igrejas pentecostais na minha aldeia Te'yikue. Por isso, quando terminei o Ensino Médio, tentei fazer graduação em História, mas a dificuldade financeira me impediu de fazer. Mesmo assim não desisti, fiz vestibular no Teko Arandu, com intuito de cursar Licenciatura Indígena, na UFGD. Fui aprovado em décimo colocado.

Desde então, comecei a estudar e ampliar o meu conhecimento tradicional com pesquisa e me conectando de novo com o meu mundo, do qual me distanciei, talvez por medo, ou por não entender bem o que havia acontecido com os meus parentes indígenas, e também comigo.

Transitando nestas duas realidades, eu, acadêmico da área humanas, tentando estudar o tema, tive que mergulhar muito nas pesquisas, onde me tornei mais pesquisador indígena e sabendo dialogar com vários parentes meus e com as demais pessoas da comunidade.

Tive necessidade de conhecer melhor a minha realidade e da minha aldeia, por isso, me aproximei mais dos rezadores e dos fiéis indígenas, principalmente dos meus parentes familiares, ondes os mesmos me contavam suas ideias sobre a aldeia, evangelização, cultura, sobretudo sobre os rezadores da aldeia. Participei de várias reuniões na aldeia e na escola, onde 
os pais reivindicaram seus direitos e, ao mesmo tempo, criaram várias possibilidades aos professores indígenas de pensarem solução para os problemas apresentados.

Quando comecei a cursar a graduação, tive vários professores que trabalharam vários textos, pesquisas que já foram feitas sobre o povo da minha etnia Guarani Nhandéva e dos Kaiowá, sobre a educação escolar indígena, SPI, invasão dos colonos, colonização, entre outros. Portanto, nesse período de estudo, eu já sabia o que eu queria para minha formação. Todos os textos ajudaram-me a entender mais sobre a minha realidade e dos Guarani e Kaiowá; o que me estimulou a fazer um TCC sobre a realidade da reserva, em que procurei entender mais a percepção da comunidade acerca da "reserva indígena", o que me instigou a continuar com essa pesquisa.

Optei em cursar esse curso, pois precisava entender o processo histórico do meu povo Guarani e Kaiowá, a realidade da reserva e assim possibilitar-me em estudar o tema pouco explorado pelos pesquisadores indígenas. Quando escolhi o tema sobre as igrejas instaladas na reserva de Caarapó e dos rezadores que no ponto de vista de muitos crentes, pareciam que estavam sendo dominados ao mesmo tempo silenciados, por outro lado os ñanderu e as ñandesy mostraram que não estavam dominados completamente, pois os mesmos conseguiram resistir a vários problemas e às violências advindas do processo de colonização e de evangelização de indígenas.

Sendo assim, todas essas fases descritas auxiliam-me a pensar as transformações que ocorrem na minha comunidade. Ser pesquisador dessa temática não é uma tarefa fácil, todavia, é importante que nós pesquisadores indígenas tenhamos compromisso em problematizar essa realidade, sobretudo no que diz a expansão religiosa na aldeia.

O contato mais direto que eu tive com rezadores foi depois que entrei na graduação, participando dos Encontros dos Acadêmicos, do Encontro de Professores e Aty guasu, lendo textos de alguns pesquisadores não indígenas, nos quais estavam Melià, Brand, Levi Marques Pereira, Cavalcante, entre outros.

\subsection{Entre Rezadores e Professores: A Educação Escolar Indígena a partir das alianças institucionais}

Uma das alternativas usadas pelos rezadores foi se aliar com os professores, certos de que serão valorizados por eles e fortalecê-los, nesse caso, contribuíram bastante no registro dos nomes de plantas medicinais, das rezas, até na formação de novos detentores de saberes 
indígenas, ou seja, novos conhecedores de remédios e de rezas, isso foi o caso do professor Nilton Ferreira Lima, hoje professor da área de Ciências da Natureza e atua como professor na Unidade Experimental, onde se ensina aos alunos várias práticas agroecológicas na perspectiva sustentável. A comunidade dessa localidade foi exposta às mais diversas formas de exploração, à negação do seu direito e ao preconceito, portanto, ficava quase impossível reivindicar o reconhecimento e aperfeiçoamento de sua medicina tradicional ao estado e ao município.

Podemos definir essa fase da reivindicação dos indígenas de garantir direito à saúde de qualidade e de construção da escola indígena como "tesãi reka"8. O movimento foi articulado para garantir primeiramente o território, a saúde diferenciada e a escola, em contraposição às situações vividas no passado, quando "o índio não tinha direito", até porque nós indígenas temos múltiplas culturas, línguas, crenças, valores e estruturas próprias de educação.

O “tesãi reka” iniciou-se com a grande retomada, ${ }^{9}$ na década de 1980 , até porque a violência física imposta aos Kaiowá e aos Guarani foi extensa, sendo o processo de expulsão das terras que tradicionalmente ocupavam, acompanhado por formas de violência simbólica.

A partir da força de resistência e de habilidade de articulação, retornaram às suas áreas tradicionais, constituindo, assim, vários tekoha, por exemplo, Guyra Roka, Taquara, Jarara (Juti-MS). A sociedade karai (sociedade branca) instituiu por várias décadas um completo encobrimento da sociedade indígena em sua alteridade, para assim justificar a violência, violação de direito em relação à terra, saúde, educação, e à desqualificação de protagonismo e da estrutura organizacional tradicional de comunidade organizada com vínculos históricos com determinados territórios, nos quais se desenvolviam o teko mbo'e, teko porã e teko resãi (bem viver e a vida saudável).

Vale destacar a trajetória de construção da escola indígena na Reserva indígena de Caarapó que, segundo Benites (2014), se originou de uma proposta feita pela Secretaria de Educação de Caarapó, em 1997, juntamente com os parceiros e as parceiras das universidades e da secretaria do estado, que priorizaram as questões indígenas. Nesse sentido, o movimento indígena foi ampliando e fortalecendo sua aliança com as entidades.

Por meio dessa aliança se viu o resultado positivo em vários aspectos da vida social, tais como saúde, educação, direito, desenvolvimento econômico (sustentável ou não), qualificação técnica profissionalizante e muitas outras. Tem sido marcante a atuação de algumas ONGs, das

\footnotetext{
8 À procura do bem viver e vida sustentável.

${ }^{9}$ Vale destacar o processo de retomada da comunidade do Rancho Jakare e Guaimbe Pery, ambas localizadas na região de Laguna Carapã/MS.
} 
Universidades, das Secretarias do Município e do Estado na Reserva Indígena de Caarapó, criando curso de formação de professores, Programa Kaiowá e Guarani (Universidade Católica Dom Bosco, Universidade Estadual de Mato Grosso do Sul e Diocese de Dourados) e a participação e articulação das lideranças da aldeia. De acordo com Benites (2014), as instituições tiveram muito respeito pela dinâmica e organização social interna, ouvindo sempre as demandas da comunidade indígena. Particularmente, para garantir a educação escolar que atenda às especificidades culturais e às demandas da comunidade, várias reuniões e ações foram feitas para garantir futuro mais próspero.

\section{Considerações Finais}

Procuramos no texto evidenciar inicialmente a partir de uma trajetória autobiográfica e, posteriormente, abordando as ações da Igreja e das alianças com outras instituições, o processo de introdução da Educação Escolar Indígena na Aldeia Caarapó-MS. A análise foi feita a partir de experiências, vivências e depoimentos de professores, rezadeiras e demais moradores da tekoha.

Procuramos caracterizar a aldeia como lugar de memória e principalmente atrelar à Educação Escolar Indígena como uma importante prática de resistência. Assim, passamos pelos processos de ressignificação de memória do indígena Elemir Soare Martins, assim como a implementação da primeira escola indígena da aldeia.

A análise foi finalizada com as alianças que foram realizadas entre índios e não-índios, a partir do estreitamento de diversas instituições, como nos casos das ONGs, Igrejas e Universidades.

O texto procurou demonstrar além da introdução da Educação Escolar Indígena, também a sua importância, tanto para o processo educacional em si, quanto para a preservação e valorização dos seus costumes e tradições.

\section{Referências}

BENITES, T. Rojeroky hina ha roike jevy tekohape (rezando e lutando): o movimento histórico dos Aty Guasu dos Ava Kaiowá e dos Ava Guarani pela recuperação de seus tekoha. 2014. 270f. Tese (Doutorado em Antropologia Social) - Universidade Federal do Rio de Janeiro, Rio de Janeiro, RJ, 2014.

\section{BENITES, E. Oguata Pyahu (Uma nova caminhada) no processo de desconstrução e}


construção da educação escolar indígena da Aldeia Te’ýikue. 2014. 130f. Dissertação (Mestrado em Educação) - Universidade Católica Dom Bosco, Campo Grande, MS, 2014.

BRAND, A. J. O confinamento e o seu impacto sobre os Guarani/Kaiowá. 1993. 276f. Dissertação (Mestrado em História) - Pontifícia Universidade Católica do Rio Grande do Sul (PUCRS), Porto Alegre, RS, 1993.

BRAND, A. J. O impacto da perda da terra sobre a tradição Kaiowá/Guarani: os difíceis caminhos da palavra. 1997. 382f. Tese (Doutorado em História) - Programa de PósGraduação em História da Faculdade de Filosofia e Ciências Humanas, Pontifícia Universidade Católica do Rio Grande do Sul, Porto Alegre, RS, 1997.

BRAND, A. J. Os complexos caminhos da luta pela terra entre os Kaiowá e Guarani no MS. Tellus, ano 4, n. 6, abr. 2004, p. 137-50, Campo Grande, MS: UCDB, 2004.

MORAES, J. A. S. O pentecostalismo autóctone na Reserva de Dourados: identidade étnica, implicações sociais e protagonismo (1992 - 2015). 2016. 215 f. Dissertação (Mestrado em História) - Universidade Federal da Grande Dourados, MS, 2016.

PIMENTEL, S. K. Elementos para uma teoria política Kaiowá e Guarani. 2012. 364f. Tese (Doutorado em Antropologia Social) - Faculdade de Filosofia, Letras e Ciências Humanas, Universidade de São Paulo, São Paulo, SP, 2012.

SILVA, A. B. da. Mais além da aldeia: Território e Redes Sociais entre os Guarani de Mato Grosso do Sul. 2007. 255 f. Tese (Doutoramento em Antropologia) - Museu Nacional, UFRJ, Rio de Janeiro, 2007.

VIETTA, K. Histórias sobre terras e xamãs Kaiowá: territorialidade e organização social na perspectiva dos Kaiowá de Panambizinho (Dourados-MS) após 170 anos de exploração e povoamento não indígena na faixa entre Brasil e Paraguai. 2007, f. 512. Tese (Doutorado em Antropologia Social), Faculdade de Letras, Filosofia e Ciências Humanas, Universidade de São Paulo, 2007. 


\title{
"TAPE, CAMINHO DE "PORÃ". A INTENÇÃO É ESTAR AO LADO DOS ÍNDIOS. MISSÃO DA IGREJA METODISTA COM OS ÍNDIOS KAIOWÁS.
}

\section{“TAPE, PATH OF POR A". THE INTENTION IS TO BE WITH THE INDIANS. MISSION OF THE METHODIST CHURCH WITH THE KAIOWÁ INDIANS}

GOMES, Maurício Antônio de Araújo ${ }^{1}$

\section{Resumo}

Objetivo: O presente artigo tem como objetivo abordar a atuação missionária da Igreja Metodista junto aos índios Kaiowá, através da Missão Tapeporã. Apresenta-se um histórico sobre o surgimento do movimento metodista no século XVIII e sua inserção do Brasil no ano de 1835. Além disso, menciona-se a posterior atuação da Igreja Metodista com a população indígena Kaiowá, pautada pelo diálogo e respeito à diversidade. A missão teve início em 1982 quando a Igreja Metodista aprovou um projeto para ser desenvolvido na Missão na aldeia Bororó, localizada em Dourado/MS. Conclusão: A missão deixa claro para os índios que o que acontece com eles é de suma importância para a igreja.

Palavras-chave: Metodismo. Missão. Kaiowá.

\begin{abstract}
Objectives: This article aims to address the missionary activity of the Methodist Church with the Kaiowá Indians through the Tapeporã Mission. It will be presented a history about the emergence of the Methodist movement in the eighteenth century and its insertion of Brazil in the year 1835 and later mentioned the action of the Methodist Church with the Kaiowá indigenous population for dialogue and respect for diversity. The mission began in 1982 when the Methodist Church approved a project to be developed at the Mission in the village Bororó located in Dourado/MS. Conclusion: The mission makes it clear to the Indians that what happens to them is of paramount importance to the church.
\end{abstract}

Keywords: Methodism. Mission. Kaiowá.

\section{Introdução}

Com tantos problemas políticos, sociais e econômicos ocorridos na região de Dourado no Mato Grosso do Sul, como por exemplo o Decreto de $1882^{2}$ que autorizou a exploração da

\footnotetext{
${ }^{1}$ Graduação em Teologia pela UMESP (Universidade Metodista de São Paulo), licenciado em História pela UNIJALES (Centro Universitário de Jales), pós-graduado em psicopedagogia e ciências da religião, mestre em Ciência da Religião pela Universidade Federal de Juiz de Fora e graduando em Direito pela Doctum. E-mail: mauricioantonio37@yahoo.com.br.

${ }^{2}$ Disponível em: http://legis.senado.leg.br/legislacao/DetalhaSigen.action?id=592214. Acesso em: 15 fev. 2021. RCMOS - Revista Científica Multidisciplinar O Saber. ISSN: 2675-9128. São Paulo, v. 02, p. 01-12, fev. 2021.
} 
erva-mate nas terras dos Kaiowá e, posteriormente, a Guerra com o Paraguai, no período de 1864 a 1870, e a Colônia Agrícola $\mathrm{Nacional}^{3}$, os índios Kaiowá sofreram muitos danos no decorrer da sua história. Neste contexto histórico, surgiu a Missão Metodista Tapeporã, que significa em guarani "Tape" caminho e "porã” bom, ou seja, a ideia é trilhar um bom caminho com os índios. A referida missão é desenvolvida junto aos índios Kaiowá na aldeia Bororó, em Dourado (MS).

Este artigo tem como tema o trabalho missionário realizado pela Igreja Metodista junto aos índios Kaiowá e será dividido em três partes. Na primeira parte, será mostrado o surgimento do Metodismo e suas condições sociais e morais na Inglaterra. É preciso ter em vista que o movimento Metodista surgiu no século XVIII, em um contexto em que as transformações industriais provocavam muitas mudanças, entre elas o êxodo rural ${ }^{4}$, acarretando alguns problemas sociais.

Na segunda parte, será abordado o Metodismo no Brasil que será apresentado desde o início da sua fundação até os dias atuais. O objetivo da Igreja Metodista no Brasil sempre foi atuar de maneira a promover a vida, a integralidade do ser humano e a proclamação do Evangelho.

Na terceira e última parte, será abordada a relação entre a Igreja Metodista e os Índios Kaiowá, contando um pouco da história da ligação entre eles. Foi no ano de 1928, que a Igreja Metodista começou sua história com o povo Kaiowá, no estado do Mato Grosso do Sul. Para a Missão Tapeporã, o primordial é a igreja caminhar junto com a comunidade indígena, uma vez que tudo o que lá acontece tem sempre muita relevância.

\footnotetext{
${ }^{3}$ A Colônia Agrícola Nacional de Dourados (CAND) foi criada com a preocupação do governo de povoar o País, em consequência de parcelas importantes do território nacional que estavam ocupadas por povos indígenas, bem como de assegurar a nacionalização das fronteiras. No governo de Getúlio Dornelles Vargas, inicia-se o processo de ocupação dos espaços "vazios", atraindo trabalhadores rurais movidos pela possibilidade de se tornarem proprietários de suas terras. Desse modo, a distribuição gratuita de lotes de 30ha a colonos, com a campanha "Marcha para Oeste", proporcionou a chegada de colonos de várias regiões do Brasil. A criação da colônia foi importante para a formação do campesinato na região e, também, para o surgimento dos municípios. Disponível em: http://geografiaagrariaufgdluciana.blogspot.com/2011/11/colonia-agricola-nacional-de-dourados.html. Acesso em: 15 fev. 2021.

${ }^{4} \mathrm{O}$ êxodo rural é uma modalidade de migração caracterizada pelo deslocamento de uma população da zona rural em direção às cidades, é um fenômeno que ocorre em escala mundial. Disponível em: https://brasilescola.uol.com.br/geografia/exodo-rural.htm. Acesso em: 15 fev. 2021.
} 


\section{Fundamentação Teórica}

\subsection{Surgimento do metodismo: condições sociais e morais na Inglaterra.}

O movimento metodista começou no século XVIII na Inglaterra, em um contexto em que as transformações industriais provocavam muitas mudanças, entre elas o êxodo rural, que ocasionavam alguns problemas sociais segundo Oliveira "Deve-se dizer algo da nação inglesa em tempos de Wesley. As descrições são severas; era um país rude, onde a maldade e a impiedade condenavam a maioria da população à mais vergonhosa miséria” (OLIVEIRA, 2003. p.48).

Eugene menciona, a situação social inglesa como desumana e caótica, afirmar que a classe dominante não se preocupava com a situação lamentável que viviam as classes dominadas em situação de extrema pobreza e miséria.

Havia a classe dos abastados e ricos que não se importavam com os operários e negociantes. Não se importavam com os pobres e ignorantes, não porque se julgassem melhores, mas porque eram indiferentes ao bem-estar dos seus semelhantes. Portanto, havia gente perecendo diante dos seus olhos, e eles não se importavam com isso. Não sentiam qualquer responsabilidade em promover a alegria dos seus semelhantes menos favorecidos. Estavam no caso do rico da parábola do rico e de Lázaro (EUGENE, 1945, p.13).

Nesta época, a população da Inglaterra chegou a sete milhões de pessoas que viviam em situação de extrema necessidade e miséria (BUYER, 1994). João Wesley, o fundador do movimento metodista, manifestava grande preocupação com a situação em que os pobres viviam, o que o influenciou a fazer algumas reflexões sobre a pobreza que assolava a Inglaterra. Segundo Wesley:

[...] A pobreza não traz consigo coisa pior que o fazer com que os homens se tornem sujeitos à mofa. Mas, não é a falta de alimento pior do que isso! Deus proclamou como maldição sobre o homem o fato de que ele deveria ganhar o pão com o suor do seu rosto. Mas, quantos há neste país cristão que trabalham e suam e, afinal, não tem que lutar contra a tristeza e fome! Não é triste para alguém, depois de um dia pesado de trabalho chegar à sua casa pobre, suja e sem conforto, e não encontrar pelo menos o alimento necessário à reparação de sua energia gasta! Refleti, vós que tendes vida tranquila na terra e de nada tendes necessidade [...] (WESLEY, 1995, p. 229-230).

A situação também era difícil para os comerciantes, pois as estradas eram ruins e o transporte de mercadoria acabava tendo um preço elevado e, consequentemente, havia o encarecimento das mercadorias para a população. Mas, outros fatores também contribuíram para tal situação, como a pouca variedade de mercadoria, falta de clientela, baixos salários e 
altos impostos sobre as mercadorias. Neste contexto de miséria, era inevitável que a violência proporcionasse o aumento da criminalidade. Os problemas socio econômicos assolavam a Inglaterra.

A situação não era difícil apenas para os comerciantes, mas para os trabalhadores das classes populares se encontravam em uma situação deplorável de condições de trabalho. Vale ressalvar, os mineiros que tinham uma jornada trabalho até quatorze horas diárias em condições desfavoráveis como umidade, calor e outros. Sem mencionar a situação dos tecelões que era precária e desumana, segundo Engels

\begin{abstract}
Entre os operários em concorrência com as máquinas, os mais mal tratados são os tecelões manuais da indústria do algodão. São os mais mal pagos e, mesmo em caso do pleno emprego, é-lhes impossível ganhar mais de 10 xelins por semana. O tear mecânico disputa-lhes um tecido após outro e, além disso, a tecelagem manual é o último refúgio de todos os trabalhadores dos outros ramos que estão desempregados, se bem que este setor esteja constantemente superlotado. É por isso que o tecelão manual se julga feliz, durante os períodos médios, quando pode ganhar 6 a 7 xelins por semana e, mesmo para ganhar esta soma, é-lhes necessário trabalhar 14 a 18 horas por dia no seu tear (ENGELS, 2010. p. 185).
\end{abstract}

Diante das remotas e lamentáveis condições trabalhistas o analfabetismo era quase generalizado nas classes populares, pois a educação, ou seja, ler e escrever pertencia apenas as classes dominantes.

Com esta precariedade social, na qual a pobreza e a miséria permeavam grande parte da população, era de se esperar que as condições morais também fossem as piores possíveis. Entretanto, não se deve generalizar uma afirmação desse tipo, pois havia pessoas de boa conduta nesta sociedade.

A prática de jogos de azar era algo comum, mas também existiam jogos com uso de animais, como por exemplo as rinhas de galos, além da prática de outros tipos de crueldade e, por isso, a Inglaterra era conhecida pelas nações europeias como uma nação selvagem (BUYER, 1994).

O consumo de bebidas alcoólicas de forma desordenada levou muitas pessoas ao alcoolismo e afetou ainda mais a crise na Inglaterra. Elas eram encontradas em todos os lugares, sendo que a cerveja era a mais consumida. As autoridades tentavam controlar suas fábricas, procurando excluir o vinho e outras bebidas da França e de outros países, porém o contrabando tomou conta do país. A embriaguez chegou a tal ponto que se temia que o povo inglês fosse exterminado pelo vício. Nas palavras de Donato,

Em 1750, por exemplo, foi tanto o álcool consumido pelo povo que os médicos ficaram alarmados com o grande número de doentes que apareceram, sendo só em Londres mais de quatorze mil casos. Da mesma forma, a pobreza e o analfabetismo se espalharam cada vez mais. Os impostos que recaíam sobre os pobres foram 
triplicados de 1714 a 1750 . Os crimes e as desordens eram muito comuns nas cidades, apesar da severidade das penas legais (DONATO, 2013, p. 13).

Como relatado até aqui, a situação social e moral na Inglaterra no século XVIII não era das melhores, porém a crise também apresentava sua dimensão religiosa. O cristianismo na Inglaterra foi introduzido por Santo Agostinho de Cantuária, no século VI, cuja intenção era converter o Rei Etelberto, cuja esposa, a rainha Berta, era cristã (HEITZENRATER, 2006). Em seguida, o cristianismo se espalhou pelas ilhas britânicas e tornou-se nacionalista, centralizouse na monarquia e se tornou fortemente antipapal. Vale mencionar que até o reinado de Henrique VIII, a religião oficial era o Catolicismo Romano. Destaca-se também o advento da Reforma Protestante na Europa preconizada pelo monge católico romano Martinho Lutero na Alemanha.

Neste período, o monarca na Inglaterra era o rei Henrique VIII, que foi o protagonista do surgimento da Igreja Anglicana ${ }^{5}$, que não era teologicamente protestante nos moldes calvinista e nem luterana, mas sim antipapista. Algumas mudanças introduzidas diferenciaramna do catolicismo, inclusive sob a influência do movimento protestante ${ }^{6}$ (HEITZENRATER, 2006).

A Igreja Anglicana vivenciava uma crise, pois criou uma dependência do rei, o qual era visto como "[...] o cabeça da Igreja” (BUYER, 1994, p. 19). Os clérigos procuravam proteção do rei e em contrapartida os servia. Consequentemente, o povo era esquecido. Isto gerou uma descrença nas doutrinas da Igreja, sendo que muitos se tornaram viciados em bebidas alcoólicas e jogos de azar.

A igreja Anglicana diante da crise social apresenta indícios que deixou os pobres sem uma atuação para ajudar os tais necessitados, visto que ela vivia um momento burocratização e com um grande formalismo religiosos e litúrgico. Segundo Thompson

A letargia e o materialismo da Igreja Anglicana do século 18 eram tais que, ao final e contra os desejos de Wesley, o ressurgimento evangélico resultou na Igreja Metodista.

\footnotetext{
${ }^{5}$ Rei Henrique VIII casou-se com Catarina, a viúva de seu irmão Arthur, mas decidiu repudiá-la por não ter lhe dado um herdeiro ao trono. O casal teve cinco filhos que morreram, apenas uma sobreviveu, Maria Tudor. Como Catarina não podia lhe dar filhos, Henrique VIII tentou convencer o Papa Clemente VII a conceder-lhe a anulação de seu casamento. Como as leis canônicas da Igreja Romana não permitiam o divórcio, o rei rompeu com Roma e criou, por meio de um ato do Parlamento em 1534, a Igreja da Inglaterra (Igreja Anglicana), declarando-se Chefe Supremo da Igreja. Nessa ocasião, a Igreja Anglicana passou a ser a Igreja oficial do Estado.

${ }^{6}$ A história da Igreja Anglicana é marcada por oscilações pendulares em relação ao catolicismo romano e ao protestantismo. Quando Henrique VIII separou a Igreja da Inglaterra do Catolicismo Romano (1534), todos compreendiam que a mudança fora apenas de mandatário: de um Papa para um Rei. Mas a liturgia e a estrutura hierárquica continuavam as mesmas. Nos anos seguintes é que, através de contatos com luteranos e calvinistas da Europa continental, a liturgia anglicana foi reformulada (o primeiro Book of Common Prayer é de 1549) e elaborou-se uma declaração doutrinária, os "39 Artigos de Religião". Disponível em: file://C:/Users/SONY/Downloads/1706-3541-1-PB.pdf.Acesso em: 15 fev. 2021.
} 
E ainda assim o Metodismo vinha profundamente marcado pelas suas origens; a Dissidência dos pobres de Bunyan, Dan Taylor e - posteriormente - dos metodistas primitivos era uma religião dos pobres; o wesleyanismo ortodoxo se manteve tal como iniciara, isto é, uma religião para os pobres (THOMPSON, 1987. p.37, 38).

Sendo, assim a Igreja Anglicana estava pactuada com as classes dominantes da Inglaterra e necessitava de suas contribuições para sobreviver. A Inglaterra vivencio uma profunda crise social que teve uma enorme consequência para todas as camadas sociais e principalmente para os pobres.

\subsection{Breve relato sobre a vida de João Wesley}

É neste contexto da Inglaterra que nasceu John Wesley, na cidade Epworth, em 17 de junho de 1703. Era filho de Susanna Annesley e Samuel Wesley, um pastor anglicano. No ano de 1720, Wesley foi para Oxford estudar no Christ Church e adquiriu o bacharelado em teologia em 1724. No ano seguinte, foi ordenado diácono da Igreja Anglicana e, posteriormente, em 1727, conquistou o grau de mestre em teologia. Em 1728, foi ordenado presbítero e em 1729 assumiu a cátedra do Lincoln College. Ele também foi professor, lecionando sobre o Novo Testamento, Cultura Grega, Filosofia e Lógica.

No ano de 1729, o irmão de John Wesley, Charles Wesley, criou em Oxford um grupo entre amigos com a finalidade de estudar e se ajudarem nas atividades acadêmicas e religiosas, como ir à igreja, orar e dialogar sobre assuntos da vida religiosa. Esse grupo se reunia frequentemente e foi se expandindo. Seus membros começaram a visitar os presos e alfabetizálos, e faziam com pobres e crianças órfãs. Não demorou muito para serem notados e apelidados de "Clube dos Piedosos", "Traças da Bíblia", "Sacramentinos”. Finalmente, em 1731, o grupo foi chamado de Metodista de Oxford.

No ano de 1735, John Wesley foi convidado para ser missionário na Geórgia (nova colônia inglesa na América - EUA) para evangelizar os índios, mas nessa tarefa ele não foi bem-sucedido, pois passou por grandes dificuldades e acabou se frustrando. Em dezembro de 1737, John Wesley retornou à Inglaterra e percebeu que o movimento wesleyano metodista estava sobrevivendo em Oxford e se espalhava por outras áreas.

[...] João Wesley foi missionário entre os índios na Geórgia, na América do Norte. Ele não ficou lá muito tempo e não consta que ele tenha convertido nenhum índio lá. [...] Em 1787, já na Inglaterra, ele manifestou, através de uma carta escrita a Francis Asbury, a sua preocupação para com os índios das Américas, devido ao 'fato desconcertante de que não tivesse sobrevivido nem 1\% desses índios' [...] (COLÉGIO EPISCOPAL, 1999, p. 7). 
No dia 24 de maio de 1738, Wesley foi a uma reunião na Rua Aldersgate, em Londres. Chegando ao local, ele encontrou uma pessoa que lia o prefácio de Martinho Lutero sobre a epístola aos Romanos, que descrevia a transformação que Deus realiza no coração pela fé em Cristo. Misteriosamente, John Wesley sentia o coração aquecer e começou a crer em Cristo, apenas em Cristo para salvação. Esse momento em sua vida ficou conhecido como "Experiência do Coração Aquecido", e esse fato mudou a sua vida ministerial. Segundo Eliade, "o homem toma conhecimento do sagrado porque esse se manifesta, se mostra como algo absolutamente diferente do profano" (ELIADE, 1999, p. 17). Essa experiência o fez intensificar mais as suas pregações ao ar livre, e muitas pessoas se tornaram adeptas do movimento metodista. Havia também a promoção de obras sociais que proporcionavam a inclusão e dignidade das pessoas. Segundo Otto, tratava-se do aspecto energético, como "vivacidade, paixão, natureza emotiva, vontade, força, comoção, excitação, vontade, gana" (OTTO, 2007, p.21).

O movimento metodista se expandiu pela Inglaterra através dos pregadores leigos (pregadores sem formação teológica) que iam ao local onde o povo se encontrava e, posteriormente, esses pregadores divulgaram a mensagem metodista em outros países. John Wesley faleceu no dia 2 de março de 1791 (HEITZENRATER, 2006) e o movimento metodista continuou se expandindo e se alicerçando por outros lugares.

\subsection{O metodismo no Brasil}

Aos 19 dias do mês de agosto do ano de 1835, desembarcou o primeiro missionário metodista na cidade do Rio de Janeiro, procedente dos EUA. Ele se estabeleceu na cidade, aguardou por algum tempo e organizou a primeira Igreja Metodista. Após um ano de permanência na cidade, esse missionário, Rev. Fontain E. Pitts, retornou aos EUA e lá chegando recomendou que outras missões fossem estabelecidas no Brasil. Outros missionários vieram para o País, a fim de instalar missões nas cidades. Foi um período de atividades intensas e de grandes lutas e dificuldades em função, especialmente a intolerância religiosa caracterizada na época. No ano de 1866, um expressivo número de norte-americanos veio para o Brasil devido à derrota que sofreram no período da guerra civil. Dentre muitos, estava Junius E. Newman, pastor metodista que, em agosto de 1871, organizou uma igreja em Santa Bárbara d'Oeste (SP).

Findando as últimas décadas do século XIX até as três primeiras décadas do século XX, houve uma forte ampliação das igrejas por meio da ação missionária de cristãos metodistas, 
clérigos e leigos na divulgação do Evangelho. Neste mesmo período, ocorreu o estabelecimento de quase todas as escolas metodistas que atuam até hoje no País.

Em 2 de setembro de 1930, deu-se a "Autonomia" da Igreja Metodista do Brasil, com fortes implicações. Desde esse período até os dias atuais, busca-se sempre a constituição de uma Igreja Metodista Brasileira, não sectária e em diálogo constante com o mundo no qual vivemos.

Em 1982, por ocasião do XIII Concílio Geral, a Igreja Metodista reavaliou suas práticas, à luz da dinâmica da memória e da tradição. Também admitiu o documento "Plano para a Vida e Missão”, com forte impulso na redefinição dos rumos e prioridades para seu futuro, sejam nas ações eclesiásticas, ou na ação social e na educação, todas fundamentalmente missionárias.

A Igreja Metodista do Brasil entende que a missão de Deus no mundo é estabelecer o Seu Reino, portanto participar da construção do Reino de Deus em nosso mundo, pelo Espírito Santo, constitui-se em uma tarefa evangelizante da Igreja (METODISTA, 2012).

Diante deste fato, a Igreja Metodista no Brasil atua de maneira a promover a vida, a integralidade do ser humano e a proclamação do Evangelho. Empenha-se em obras sociais e apresenta uma educação de qualidade, dedica-se em anunciar os ensinamentos de Jesus que compõem a missão da Igreja em participar da missão de Deus. No próximo tópico, será apresentada a relação entre a Igreja Metodista e os índios Kaiowá.

\subsection{A igreja metodista e os índios Kaiowá}

Os índios Kaiowá fazem parte de um subgrupo dos Guaranis (Ñandéva, os Mbüá) ${ }^{7}$, porém é o único que atualmente não usa a autodenominação Guarani (SCHADEN, 1962). A reserva onde habitam os Kaiowá fica a dez quilômetros da cidade de Dourado, no Mato Grosso do Sul, sendo cortada por uma rodovia que liga Dourados às cidades Itaporá e Ponta Porã. Segundo Costa,

A partir de 1981 o SPI - Serviço de Proteção ao Índio - hoje a FUNAI, na época chefiada pelo Marechal Rondon, começou a demarcar essas áreas... O resultado é que a reserva era pequena e foi dividida ao meio, em cima ficam Os Terena, em baixo os Kaiowá. Ficou corregozinho que nem água tem mais, o chamado de "farinha seca" como divisa geográfica dentro da reserva (COSTA, 1992, p. 80).

7Há, contudo, entre os subgrupos guarani-ñandeva, guarani-kaiowa e guarani-mbya existentes no Brasil, diferenças nas formas linguísticas, costumes, práticas rituais, organização política e social, orientação religiosa, assim como formas específicas de interpretar a realidade vivida e de interagir segundo as situações em sua história e em sua atualidade. Esta seção privilegia informações sobre os grupos ñandeva e kaiowa. Há uma seção específica dedicada aos Mbya. Disponível em: https://pib.socioambiental.org/pt/Povo:Guarani_Kaiow\%C3\%A1. Acesso em: 15 fev. 2021. 
Nos dias atuais, os indígenas vivem nessa reserva sobre a proteção do Serviço de Proteção ao Índio - SPI, onde desenvolvem atividades agrícolas, como o cultivo de ervas medicinais e a caça.

No ano de 1928, a Igreja Metodista começou sua história com o povo Kaiowá, no estado do Mato Grosso do Sul, com a participação do médico Nelson Araújo, recém-formado, e o agrônomo Francisco Brianezi, ambos da cidade de Juiz de Fora (MG). Segundo Ramiro,

O médico Nelson Araújo começou a trabalhar em 1929 e, posteriormente, teve apoio do metodista e técnico agrícola Francisco Brianezi. Eles integravam uma equipe da Associação Evangélica de Catequese aos Índios, em parceria com as Igrejas Presbiteriana Independente e do Brasil (RAMIRO, 2012, p. 8).

Havia uma parceria entre a Igreja Presbiteriana do Brasil, Igreja Presbiteriana Independente e Igreja Metodista, formando um grupo de catequese chamado "Missão Caiuá"8, cujo objetivo era evangelizar os índios, oferecer escola, assistência agrícola, assistência médica e outras atividades.

A Igreja Metodista se manteve nessa parceria até o ano de 1946, e o rompimento se deu por questões eclesiásticas e doutrinárias. Posteriormente, em 1971, o pastor Scilla Franco voltou à região de Dourados (MS) para desenvolver atividades pastorais em uma igreja local e implantar o Plano Piloto da Igreja Metodista, que visava acompanhamento e apoio aos pequenos agricultores. Consequentemente, no ano 1972, é reiniciada a missão entre os índios, havendo um compromisso de não realizar proselitismo.

Vale ressalvar que o pastor Scilla Franco permaneceu na missão até 1977, sendo obrigado a se afastar devido a problemas de saúde. No ano de 1978, a Igreja Metodista implantou a Missão Tapeporã ${ }^{9}$ com os Kaiowá, sendo os responsáveis pela missão o Rev. Paulo da Silva Costa e a Revda. Maria Imaculada da Costa e uma liderança indígena local. Ali eram desenvolvidas muitas atividades como auxílio à saúde, horta de ervas medicinais, programa de auxílio escolar e outros. Em 1994, surgiu a atividade conhecida como a vaca mecânica que visava a produção de leite de soja que era distribuído entre a população e as escolas na reserva, sendo que os bagaços eram aproveitados para a fabricação de bolos, pães, biscoitos e tortas. Diante do desenvolvimento da Missão Tapeporã, a Igreja Metodista organizou o Grupo de

\footnotetext{
${ }^{8}$ A Missão Evangélica Caiuá, agência missionária que atua entre os indígenas, foi criada em 28 de agosto de 1928 , fruto do sonho de Albert Maxwell, pastor presbiteriano norte-americano que veio ao Brasil para investir na expansão do evangelho, após ter vendido todos os bens que possuía nos Estados Unidos. Disponível em: http://www.ipb.org.br/evangelizacao/missao-caiua. Acesso em: 15 fev. 2021.

9 “"...] a Igreja começou a assumir o Plano Piloto como 'Missão Tapeporã'. O projeto se identificou como o apoio agrícola e se desdobrou em vários subprojetos, aumentando sua área de atuação" (DIRETRIZES PASTORAIS PARA A AÇÃO MISSIONÁRIA INDIGENISTA, 1999, p. 10).
} 
Trabalho Indigenista (GTI) para a elaboração de uma política que norteasse a missão com os povos indigenista. Segundo o Colégio Episcopal,

[...] o colégio Episcopal aprovou o documento "Bases para uma política Indigenista da Igreja Metodista" [...]. A parti de 1992 começou a reunir-se um grupo mais amplo de pessoas e verificou-se que ações de serviços e solidariedade já vinham se expandido para vários povos indígenas do Brasil [...] (COLÉGIO EPISCOPAL, 1999, p. 11).

No ano de 1999, foi elaborado o documento Diretrizes Pastorais para a Ação Missionária Indigenista, sendo que a base do texto era voltada para a orientação do trabalho missionário e contra o proselitismo.

O documento começou com a apresentação da sua finalidade para auxiliar todos e todas que são desafiados e desafiadas a batalhar pela causa indígena. Na sequência, há um histórico sobre a preocupação de João Wesley com os índios e depois uma abordagem das atividades realizadas pela Igreja Metodista brasileira. Foram apresentadas também as diretrizes posse de terra, direitos dos povos indígenas, autodeterminação dos povos indígenas, pastoral de convivência, ecumenismo prático, construção da Missão Indigenista à sociedade e, posteriormente, a conclusão e anexos.

A Missão Tapeporã encontrou grandes desafios devido à população de 12 mil índios alocados em uma reserva de 3,5 hectares e a sua proximidade com a zona urbana, além também da falta de recursos financeiros. Mesmo assim, continuou sua missão junto à população indígena, criando missões como: Missão Tremembé na cidade de Itarema no Ceará, Missão Maruwai em Roraima, no ano 1989, alcançando outros povos como os Krenak (MG), Tapeba (CE), Pataxó (MG), Kangaing (RS), Terena (RS), Nãndeva (MS), Kiriri (BA) e Kanamari (AM).

Nos dias atuais, a Missão desenvolve atividades com as crianças, através do Projeto Sombra e Água Fresca. Os pastores colaboram com as escolas de ensino infantil. Assim, foi construído um espaço para celebração, lazer, recreação e outras atividades com muito respeito e diálogo.

\section{Considerações finais}

Os missionários protestantes, ao chegarem à Reserva Indígena em Dourados (MS), desenvolveram um espaço de convivência à base de contato e troca com os índios. Assim, conceberam uma imagem a respeito dos índios por uma necessidade de recursos materiais, 
espirituais e civilizatórios para justificarem a ação catequizadora. Os índios viram nos missionários o meio de adquirir os recursos que necessitavam.

Os missionários encontraram grandes desafios como o tamanho da população indígena que chegava a uma média de doze mil índios e a grande falta de recursos. Porém, eles sempre trataram todos os índios com muito respeito, dignidade e ética, inclusive lutando lado a lado com eles pelos seus direitos.

A Igreja Metodista, ao romper com a Missão Caiuá e depois de anos ao retornar com a Missão Tapeporã com os Kaiowá, fez um comprometimento de não fazer o proselitismo e sempre buscar uma conversão da própria igreja, proporcionando respeito e diálogo com eles.

Mesmo que a Igreja Metodista fez o compromisso de não realizar o proselitismo, percebe-se que tanto contexto cristão católico e protestante que a população indigenista sempre foi alvo de suas missões e as práticas proselitistas que estão presentes e desconfiguram a cultura indígena.

Na prática milhares índios através dos trabalhos missionários convertem ao cristianismo e há um processo de assimilação entre as religiões proporcionando assim em muitos casos um cristianismo híbrido.

\section{Referências}

BRASIL. SENADO FEDERAL. Atividade Legislativa. Legislação. Disponível em: http://legis.senado.leg.br/legislacao/DetalhaSigen.action?id=592214. Acesso em: 22 out. 2018.

BUYER, P. E. História do Metodismo. São Bernardo do Campo: Imprensa Metodista, 1994.

COLEGIO EPISCOPAL. Diretrizes Pastorais para a Ação Missionária Indigenista.

Biblioteca Vida e Missão. Documento n 9: São Paulo, 1999.

COSTA, MARIA IMACULADA. O Suicídio Entre Os Kaiowá. KEMPER, T.; SILVA, J. B. (Orgs.). Repensando a Evangelização Junto Aos Povos Indígenas. São Bernando do Campo: Editeo, 1994.

DONATO, R. G. De Oxford até nós. Muriaé. MG: o Autor, 2013.

ENGELS, F. A situação da classe trabalhadora em Inglaterra. Tradução B. A. Schumann. São Paulo: BOITEMPO EDITORIAL. 2010

EUGENE BUYERS, P. História do Metodismo. São Bernardo do Campo, SP: Imprensa Metodista, 1945. 
HEITZENRATER, R. P. Wesley e o povo chamado metodista. 2. ed. São Bernardo Campo, SP: Editeo, 2006.

METODISTA, Igreja. Cânones da Igreja Metodista 2012. Piracicaba, SP: Equilíbrio Editora, 2012.

MIRCEA, E. O sagrado e o profano. São Paulo: Martins Fontes, 1999.

OLIVEIRA LOCKMANN, P. T. Wesley e os Pobres. In: Caminhando: 300 anos de Wesley. Ano VIII, n. 12, 2. Semestre de 2003. p.48.

OTTO, R. O Sagrado. Petrópolis: Vozes, 2007.

RAMIRO, M. Igreja Metodista: desde 1928 a serviço dos povos indígenas. Expositor Cristão. São Paulo: Imprensa Metodista, 2012.

REILY, D. A. Missão, Organização e Agentes do Metodismo. São Paulo: Imprensa Metodista, 1997.

SALLE, L. Geografia Agrária. Disponível em:

http:/geografiaagrariaufgdluciana.blogspot.com/2011/11/colonia-agricola-nacional-dedourados.html. Acesso em: 22 out. 2018.

SCHADEN, E. Aspectos Fundamentais da Cultura Guarani. São Paulo: EDUSP, 1962.

THOMPSON, E. P. A formação da classe operária inglesa, v. I, A árvore da liberdade. Rio de Janeiro: Paz e Terra, 1987a.

WESLEY, J. Coletânea da teologia de João Wesley. Tradução: Messias Freire. Rio de Janeiro: Setor de Publicações da Pastoral Bennett Instituto Metodista Bennett, 1995.

\section{Sites}

A tensão entre Substância Católica e Princípio Protestante no Anglicanismo. Carlos Eduardo Calvani. Disponíveis em: file:///C:/Users/SONY/Downloads/1706-3541-1-PB.pdf/. Acesso em: 20 jan. 2021.

O Metodismo no Brasil. Disponível em: https://www.metodista1re.org.br/o-metodismo-nobrasil/. Acesso em: 23 jan. 2021.

Raízes Históricas do Metodismo Brasileiro. Disponível em:

https://www.metodista.br/revistas/revistas-

ims/index.php/Caminhando/article/viewFile/1204/1215/. Acesso em: 19 jan. 2021.

Metodismo no Brasil. Disponível em

http://www.metodistavilaisabel.org.br/metodismo/brasil.asp/ Acesso em: 25 jan. 2021. 


\title{
A LEITURA LITERÁRIA EM SALA DE AULA: CONTRIBUIÇÕES NO DESENVOLVIMENTO DA REFLEXÃO CRÍTICA
}

\section{LITERARY READING IN THE CLASSROOM: CONTRIBUTIONS TO THE DEVELOPMENT OF CRITICAL REFLECTION}

MORAES, Jorge Adrihan do Nascimento de ${ }^{1}$

\section{Resumo}

Objetivos: O presente artigo apresenta as contribuições da literatura no desenvolvimento da reflexão, evidenciando que os textos literários não podem ser encarados somente a partir da competência de interpretação de textos, mas também na capacidade de ampliação de visão de mundo, a partir da reflexão. Diante disso, com base em pesquisas bibliográficas, o estudo conseguiu se aprofundar nos aportes que a literatura fornece para ampliar o pensar do educando. Metodologia: Para que se possa realizar a abordagem, de início o estudo trata das competências da Literatura segundo a BNCC (2017). Após, apresenta as competências na leitura de textos literários, finalizando com uma abordagem da literatura no desenvolvimento da reflexão. Para tal, baseia-se em Cosson (2018), Candido (2002) e Bunzen e Mendonça (2006). Conclusão: Logo, o estudo diagnosticou o quanto a literatura contribui no desenvolvimento da reflexão do aluno, pois há uma aproximação do educando com o autor, chegando a uma identificação e reflexão de sua própria realidade.

Palavras-chave: Literatura. Leitura. Reflexão. Textos Literários.

\begin{abstract}
Objectives: The present article presents the contributions of literature in the development of reflection, showing that the literary texts cannot be considered solely from the evolution in the competence of interpretation of the texts, but also in the capacity of amplification of world view, reflection. In view of this situation, based on bibliographic investigations, the studio managed to deepen the contributions that literature provides to broaden the thinking of the student. Methods: In order to be able to carry out the approach, from the beginning the studio deals with Literature competences according to the BNCC (2017). Afterwards, it presents the competences in the teaching of literary texts, ending with an approach to Literature in the development of reflection. For him, it is based on Cosson (2018), Candido (2002) and Bunzen y Mendonça (2006). Concludes: Therefore, the study diagnosed how much literature contributed to the reflection of the aluminum, because there was an approximation of the educator with the author, using an identification and reflection of his own reality.
\end{abstract}

Keywords: Literature. Reading. Reflection. Literary texts.

\footnotetext{
${ }^{1}$ Doutorando em Ciências da Educação, pela Universidad Columbia del Paraguay. Mestrando em Literatura, Cultura e Contemporaneidade, pela Pontifícia Universidade Católica do Rio de Janeiro. Fundador e Gestor Pedagógico do IDEHP - Instituto de Desenvolvimento Humano e Profissional. Professor do Ensino Básico e Superior. E-mail: jorgeadrihan@hotmail.com
}

RCMOS - Revista Científica Multidisciplinar O Saber. ISSN: 2675-9128. São Paulo, v. 02, n. 2, p. 01-11, fev. 2021. 


\section{Introdução}

A Literatura está presente na vida escolar de um indivíduo desde que este inicia sua trajetória nas instituições educacionais. Durante o ensino fundamental I e II, os educandos entram em contato com diversos gêneros literários, os quais promovem o desenvolvimento da leitura. Quando ingressam no ensino médio, os discentes estudam os períodos literários, perpassando por clássicos autores e momentos da literatura brasileira.

No século XXI, os docentes na disciplina de Literatura incentivam os discentes a lerem diversos textos e até mesmo os livros paradidáticos, que fazem parte dos programas da disciplina em muitas instituições escolares. Muitos professores trabalham os textos literários em sala de aula, a partir do desenvolvimento da capacidade de interpretação textual dos educandos, a partir de uma simples decodificação de palavras. Porém, a literatura vai além da contribuição na competência de compreensão de textos, pois promove a reflexão crítica e conhecimento de mundo do alunado.

Muitas vezes, a literatura é trabalhada em sala de aula somente ensinando os períodos literários, os estilos e contexto histórico das produções e o aluno somente decora as informações para a realização de uma avaliação. É preciso enxergar a literatura além de um conjunto de estilos e épocas textuais, pois a leitura mediada pelo professor favorece a ampliação na reflexão do aluno.

De acordo com a Base Nacional Comum Curricular, BNCC (2017), a educação literária é diferente de leitura, pois enquanto a leitura trabalha com a compreensão de textos em suas diversas formas, a educação literária consiste no conhecimento e na apreciação da literatura escrita e oral, através do conhecimento de grandes clássicos. Logo, a educação literária promove uma leitura baseada na reflexão e construção do pensamento crítico do educando, pois este começa a apreciar um texto, enxergando-o além das palavras, realizando a construção deste com a sua realidade. Diante disso, a literatura não pode ser encarada somente a partir do desenvolvimento da competência de interpretação de textos, mas também da capacidade de ampliação de visão de mundo do aluno, pois segundo Cosson (2018) a literatura torna o mundo compreensível.

Portanto, torna-se relevante evidenciar que a literatura vai além da contribuição na leitura e interpretação textual de um indivíduo, para que seu uso por docentes na vida diária do educando em sala de aula proporcione um aumento na reflexão crítica deste, que passará a 
enxergar além do texto. Diante disso, o presente estudo possui o objetivo de apresentar as contribuições da literatura no desenvolvimento da reflexão crítica.

\section{Materiais e métodos}

O presente estudo caracteriza-se pela abordagem do tipo qualitativa, com revisão da literatura pertinente à investigação. Segundo Gil (2010), nesta perspectiva, percebe-se que a pesquisa bibliográfica se utiliza de dados existentes. Portanto, o presente artigo foi construído por meio de pesquisa bibliográfica, com revisão da literatura, que para Lakatos e Marconi (2003, p. 248): "consiste em uma síntese, a mais completa possível, referente ao trabalho e aos dados pertinentes ao tema, dentro de uma sequência lógica.” Dessa forma, possibilitou contatar direta e indiretamente com fontes de conhecimentos legitimados cientificamente. Caracteriza-se pela abordagem qualitativa, de natureza básica, pois para Gil (1999, p. 42) denota que essa natureza "procura desenvolver os conhecimentos científicos sem a preocupação direta com suas aplicações e consequências práticas.” Quanto aos objetivos, a pesquisa é exploratória, pois visa "proporcionar mais familiaridade com o problema", de acordo com Gil (2002, p. 41).

Neste sentido, para que se possa realizar a abordagem, de início o estudo trata das competências da Literatura, segundo a BNCC (2017). Após, apresenta a leitura de textos literários, finalizando com uma abordagem das contribuições da literatura na reflexão crítica.

Como arcabouço teórico, são utilizadas algumas obras como "Letramento Literário", de Cosson (2018) e "Português no ensino médio e a formação do professor", de Bunzen e Mendonça (2006). Além do uso dessas obras, o artigo se utiliza de livros e artigos de autores consagrados em relação ao tema abordado.

\section{Resultados e discussão}

\subsection{As competências da Literatura segundo a BNCC}

A literatura e a leitura de textos literários são encaradas pelos educandos muitas vezes como algo cansativo e entediante. Isto porque os textos não são utilizados em sala de aula, a partir do objetivo de promover uma educação literária, mas para somente uma decodificação de palavras e expressões. Por isso, os alunos não chegam a uma reflexão crítica da obra RCMOS - Revista Científica Multidisciplinar O Saber. ISSN: 2675-9128. São Paulo, v. 02, n. 2, p. 01-11, fev. 2021. 
proposta. De acordo com Cosson (2006), a partir da leitura de textos literários, um indivíduo começa a compreender o mundo e o que está ao seu redor. Ele passa a identificar que os anseios transmitidos pelo autor da literatura são os mesmos dos homens contemporâneos e que os sentimentos e emoções que constam nas palavras podem se comparar aos seus. Logo, o educando começa a sentir o mundo a sua volta, levando-o a uma reflexão de suas próprias vivências.

A Base Nacional Comum Curricular, BNCC (2017), como um documento que norteia as aprendizagens essenciais de um educando, bem como as competências que este deve desenvolver ao longo de sua vida escolar, em todas as áreas de conhecimento, apresenta o ensino de Literatura na Educação Básica, discorrendo como essa disciplina deve ser desenvolvida no aluno, as capacidades que devem promover a este e as funções que esta área possui na vida escolar.

De acordo com a BNCC (2017), durante o ensino fundamental, o educando realiza uma análise das manifestações artísticas-literárias e como essas se reproduzem em sua vida diária. Neste segmento de ensino, não há a disciplina de literatura na grade do aluno, mas os textos e gêneros literários são trabalhados dentro da disciplina de Língua Portuguesa. Quando os alunos iniciam o ensino médio, a Literatura já se faz presente como uma disciplina a parte da disciplina de Língua Portuguesa e segundo a BNCC (2017) é o momento de consolidar e ampliar o uso da reflexão.

Logo, o aluno deve desenvolver o seu pensar a partir da literatura. Os textos literários não são somente para uma interpretação textual, mas para uma aproximação do aluno com o autor e uma reflexão de sua própria realidade.

Essas demandas exigem que as escolas de Ensino Médio ampliem as situações nas quais os jovens aprendam a tomar e sustentar decisões, fazer escolhas e assumir posições conscientes e reflexivas, balizados pelos valores da sociedade democrática e do estado de direito (BNCC, 2017, p.477)

A Literatura reflete todo o contexto histórico vivido por um autor, pois este reproduz, através das palavras, todo seu sentimento, emoção e crítica em relação à sociedade, da qual participou. Quando um aluno entra em contato com os textos literários, poderá perceber que o mundo retratado pelo autor muita das vezes equipara-se ao dele, logo fará uma reflexão, assumindo posições conscientes e reflexivas.

Como linguagem artisticamente organizada, a literatura enriquece nossa percepção e nossa visão de mundo. Mediante arranjos especiais das palavras, ela cria um universo que nos permite aumentar nossa capacidade de ver e sentir. Nesse sentido, a literatura possibilita uma ampliação da nossa visão do mundo, ajuda-nos não só a 
ver mais, mas a colocar em questão muito do que estamos vendo/vivenciando. (BNCC, 2017, p.491).

Ao trabalhar um texto literário em sala de aula, o educador deve resgatar juntamente com o educando a historicidade da obra, para que seja possível perceber todo o contexto, no qual se encontrava o autor e o sentimento que este reproduz pela sociedade. $O$ aluno diagnosticará as problemáticas enfrentadas pelas gerações passadas e poderá equiparar aos problemas vivenciados por ele diariamente, assim, mais do que uma compreensão textual, o educando sentirá todo o texto, pois fará uma relação com seu próprio contexto de vida. Logo, é preciso que a Literatura seja trabalhada pelos docentes, seguindo a BNCC (2017), no que concerne à educação literária, para que as práticas pedagógicas nesta disciplina possam ir além de um conteúdo pré-programado e da simples leitura e interpretação de textos.

Aliás, como se registra nos livros didáticos, os textos literários ou considerados como tais estão cada vez mais restritos às atividades de leitura extraclasse ou atividades especiais de leitura [...]. Por isso, afirma-se que o objetivo é integrar o aluno à cultura (COSSON, 2018, p. 21-22)

Os textos literários possuem grande capacidade transformadora quando atrelados à cultura do aluno, a partir de uma leitura mediada pelo professor, o qual lhe ensinará os caminhos de uma leitura crítica. Pois, esta é a função da literatura nas escolas, pois de acordo com a BNCC (2017), essa área das linguagens possui uma forte questão social na vida escolar de um indivíduo, pois ela favorece uma ampliação da reflexão e percepção de realidades.

\subsection{A Leitura de Textos Literários}

Alguns teóricos conceituam Literatura como a arte das palavras, ou seja, a capacidade que um indivíduo tem de, através das palavras, transmitir seus sentimentos, anseios e apreensões. Sendo assim, a arte proporcionadora de prazer e alívio de sentimentos do leitor, fazendo com que esse desperte em si emoções ao entrar em contato com um texto.

É preciso considerar que, como abordava Bakhtin (1997), o leitor de um texto literário ou o contemplador dessa arte não é um ser passivo, que apenas recebe a comunicação. Os indivíduos recriam e atualizam seus sentimentos, ao entrarem em contato com um texto, mesmo estando em períodos históricos, culturais e sociais distintos. Logo, a importância do ensino de Literatura, para não somente a construção de visão crítica no educando, mas também para o despertamento de suas emoções e sentimentos. Pois, a literatura cumpre um papel humanizador, tornando os homens semelhantes. Escritor, texto e leitor dialogam entre 
si, formulando ideias e concepções que são construídas, a partir do próprio contexto de vida do que lê.

\begin{abstract}
A Literatura é o retrato vivo da alma humana; é a presença do espirito na carne. Para quem, às vezes se desespera, ela oferece consolo, mostrando que todo ser humano é igual, e que toda dor parece ser a única; é ela que ensina aos homens os múltiplos caminhos do amor, enlaçando-os em risos e lágrimas, no seu sofrer semelhante; ela é que vivifica a cada instante o fato de realmente sermos irmãos do mesmo barro. (LANES, 1978, p.15)
\end{abstract}

Um indivíduo, ao entrar em contato com um texto, percebe que tudo aquilo que ele vive no presente, suas dores, angústias, alegrias, já estiveram no passado, ao ver que o autor literário expressa as mesmas inquietações e emoções. Logo, através da literatura, o homem consegue enxergar a própria alma e ter dentro de si um despertar, para seus sentimentos, causando uma identificação e consciência de semelhança entre as pessoas.

A leitura de um texto literário é a ação de ler algo e ter a capacidade de influenciar a maneira de agir, pensar e até de falar dos indivíduos. Cada pessoa possui uma experiência própria, cotidiana e pessoal, tornando a leitura única, incapaz de se repetir. Por meio da leitura, o indivíduo resgata lembranças especiais, que fazem parte da sua cultura. Equivocadamente, o conceito de leitura na maioria das vezes, está reduzido a decifrar os códigos linguísticos e sua aprendizagem. Entretanto, não se pode deixar de levar em consideração o processo de formação social dos indivíduos.

A leitura é, pois, uma atividade interativa altamente complexa de produção de sentidos, que se realiza evidentemente com base nos elementos linguísticos presentes na superfície textual e na sua forma de organização, mas requer a mobilização de um vasto conjunto de saberes no interior do evento comunicativo. (KOCH, 2010, p. 11).

Os docentes, ao trabalharem textos literários em sala de aula, não podem somente realizar uma leitura com os educandos baseada na decodificação de palavras e na interpretação textual, a partir de questionários e compreensão de estilos e épocas. Pois, o ato de ler não está unicamente relacionado ao entendimento do texto, relaciona-se, também, ao conhecimento que o leitor tem do mundo e é esse fator que dá vida ao texto.

Não é possível aceitar que a simples atividade da leitura seja considerada a atividade escolar de leitura literária. [...]. No sentido de que lemos apenas com nossos olhos, a leitura é, de fato, um ato solidário, mas a interpretação é um ato solidário (COSSON, 2018, p.26-27)

A leitura não poder ser uma atividade na qual os docentes incumbem os alunos de lerem e interpretarem diversos textos em suas casas ou em leituras individuais em classe. Pois, essa atividade precisa ser compartilhada. Os leitores precisam expor seus sentimentos, 
suas emoções e impressões, ao lerem uma obra literária, e toda esta ação culminará em um trabalho mais eficaz no ensino de literatura. Quando os educandos partilham suas experiências, ao entrarem em contato com um texto, expressam também sua própria cultura e contexto de vida, pois antes mesmo de lerem a palavra, eles já realizaram uma leitura de mundo.

De acordo com Freire (2013), a leitura do mundo precede a leitura da palavra. Com isso, entende-se que o indivíduo adquiriu muito aprendizado através de suas vivências em sociedade, e tais vivências podem ser diferentes do que ele adquiriu no mundo da escolarização. A leitura de vários livros não adiantará se apenas forem decodificadas as palavras sem compreender o verdadeiro significado que elas possuem.

Logo, de nada adiantará utilizar a literatura em sala de aula se somente os professores a utilizarem para atividades de interpretação textual, na qual o aluno realiza somente uma busca de palavras e expressões. A leitura deve ir além, pois o educando precisa enxergar fora do texto e, para tal ação, precisa da mediação do educador, que o levará a realizar uma aproximação do texto com as suas vivências, evidenciando que os mesmos fatos, sentimentos e emoções também se equiparam aos contemporâneos. Pois, a literatura se reinventa diariamente. "O bom leitor, portanto, é aquele que agencia com os textos os sentidos do mundo, compreendendo que a leitura é um concerto de muitas vozes e nunca um monólogo". (COSSON, 2018, p. 27)

No que concerne aos Parâmetros Curriculares Nacionais (PCNs, 1998), a leitura tem uma função essencial no processo de ensino e de aprendizado dos indivíduos, levando em conta que com o desenvolvimento de sua competência leitora o indivíduo poderá se tornar proficiente em todas as disciplinas. Sendo assim, essas competências deverão ser construídas através das práticas de leitura que ocorrem dentro do ambiente da sala de aula. De acordo com os Parâmetros Curriculares Nacionais:

\begin{abstract}
A leitura é o processo no qual o leitor realiza um trabalho ativo de compreensão e interpretação do texto, a partir de seus objetivos, de seu conhecimento sobre o assunto, sobre o autor, de tudo o que sabe sobre a linguagem etc. Não se trata de extrair informação, decodificando letra por letra, palavra por palavra. Trata-se de uma atividade que implica estratégias de seleção, antecipação, inferência e verificação, sem as quais não é possível proficiência. É o uso desses procedimentos que possibilita controlar o que vai sendo lido, permitindo tomar decisões diante de dificuldades de compreensão, avançar na busca de esclarecimentos, validar no texto suposições feitas. (PCNs, 1998, p. 69 e 70).
\end{abstract}

Sendo assim, o leitor competente é aquele que está preparado para selecionar e utilizar vários textos, conseguindo entendê-los. De acordo com Koch (2010, p. 13), nesse 
apontamento dos PCNs (1998), “encontra-se reforçado, na atividade de leitura, o papel do leitor enquanto construtor de sentido, utilizando-se, para tanto, de estratégias, tais como seleção, antecipação, inferência e verificação".

Observa-se que no processo de leitura o leitor recorre a muitos conhecimentos, que vão desde o conhecimento do mundo até os conhecimentos adquiridos no espaço escolar. Koch (2010) também afirma que os leitores recorrem a muitas estratégias no que diz respeito à construção de sentido. Ler transforma as pessoas. O indivíduo modifica sua visão de mundo à medida que insere na sua vida a leitura. Portanto, os docentes precisam convidar os educandos para mergulharem nas obras literárias, de modo que a explorem sob os mais variados aspectos, pois a leitura de um texto literário se realiza de modo efetiva quando há uma profunda interação entre leitor e autor.

"Ao professor cabe criar as condições para que o encontro do aluno com a literatura seja uma busca plena de sentido para o texto literário, para o próprio aluno e para a sociedade em que todos estão inseridos" (COSSON, 2018. p.29)

Portanto, a leitura é a maneira mais antiga de adquirir conhecimento e esta não está restrita às folhas de papel, mas a uma relação entre palavras e vivências, nas quais atreladas a um texto literário desenvolve uma ampliação de visão de mundo do educando.

\subsection{A Literatura no Desenvolvimento da Reflexão Crítica}

A Literatura é uma forma de o homem expressar o que há de mais profundo em seu ser e, quando o leitor entra em contato com essa expressão, realizando uma leitura além das palavras, ele começa a refletir sobre tudo que foi evidenciado na obra. Segundo Cândido (2002), a Literatura possui três funções: psicológica, formadora e social.

Na primeira, o texto literário desperta a fantasia e imaginação do educando, pois quando este entra em contato com uma narrativa, começa a formar as cenas narradas em sua mente, proporcionando-o um pensamento criativo. $\mathrm{Na}$ segunda, tal teórico aborda que a literatura possui uma função de formar os indivíduos, no sentido de que eles identificam as realidades transmitidas pelos textos. Pois, o autor de um texto literário reproduz seu próprio contexto, muitas vezes, com uma crítica ao que está sendo vivenciado. Sendo assim, quando o educando entra em contato com uma narrativa do século $\mathrm{XX}$, que realiza uma crítica à desigualdade social, ele começa a perceber que as mesmas desigualdades existem atualmente, formando neste uma mente crítica e o seu pensar em relação ao assunto retratado. Logo, o RCMOS - Revista Científica Multidisciplinar O Saber. ISSN: 2675-9128. São Paulo, v. 02, n. 2, p. 01-11, fev. 2021. 
aluno chega à função social quando produz esta relação das histórias narradas, com seu próprio contexto.

Percebe-se que as três funções da Literatura, abordadas por Cândido (2002), devem ser exploradas pelo educador durante a leitura de um texto literário, pois elas proporcionam o desenvolvimento da reflexão do aluno. Todos os educandos para chegarem à reflexão devem ser trabalhados primeiro na imaginação, depois na identificação das vivências da narrativa em seu presente, para assim comparar as situações narradas com seu próprio contexto de vida. Pois, "A literatura atua como instrumento de educação, de formação do homem, uma vez que exprime realidades que a ideologia dominante tenta esconder" (CANDIDO, 2002, p. 85).

Diante disso, compreende-se que a capacidade de desenvolvimento de reflexão na literatura está atrelada à criticidade que muitos textos possuem, pois através das palavras, os autores literários reproduzem ideias que muitas vezes não são percebidas no cotidiano, isto pelo fato do artista da literatura ter uma sensibilidade maior para o mundo.

É preciso que a escola amplie mais suas atividades, visando à leitura da literatura como atividade lúdica de construção e reconstrução de sentido [...] não se deveria trabalhar a leitura literária apenas com a finalidade de realizar tarefas como produção resumos, preenchimento de fichas de leitura (BUNZEN; MENDONÇA, 2006, p. $85-95)$.

A Literatura vai além da produção textual, pois proporciona o pensar ao indivíduo. Antes de se trabalhar as interpretações e a produção de textos, os educandos precisam sentir tudo que é retratado na obra, precisam refletir sobre tudo que é transmitido. Pois, a escrita será suscitada a partir da reflexão. Muitos educadores trabalham a literatura com os alunos somente a partir de uma decodificação de palavras, propondo resumos e atividades baseadas em questionários que não despertam a reflexão do aluno. Ao se trabalhar a literatura em sala de aula, com o objetivo da reconstrução de sentido, é preciso levar o educando a pensar em sua própria realidade e enxergá-la no texto. Dessa forma, a literatura cumpre um papel reflexivo.

De acordo com Cosson (2018), os sentimentos despertados pelo texto literário seriam tão inefáveis que não haveria palavras para dizê-los, ou seja, não há como mensurar a capacidade de reflexão dos textos literários. Pois, o leitor desperta em si sensações ao ler, isso porque há uma troca entre visões de mundo. A Literatura é, portanto, o cumprimento da função do professor de formar cidadãos críticos, a partir de um ensino humanizado. Mais do que uma simples leitura, a literatura promove o desenvolvimento do pensar, das emoções e da criticidade. Compreende-se que, a literatura torna-se uma atividade social, com profunda 
reflexão e intensidade nas relações humanas. De forma que, educandos conseguem exprimir suas mais profundas sensações e refletir sobre suas próprias vivências, a partir da identificação.

\section{Considerações finais}

Diante das abordagens realizadas, o estudo apresentou as contribuições da literatura no desenvolvimento da reflexão, evidenciando a relevância desta na formação de alunos críticos. Compreendeu-se a importância de docentes promoverem uma educação literária em sala de aula, para que sejam desenvolvidos educandos com visão de mundo ampliada e a importância de uma prática de leitura baseada na consideração das vivências dos alunos e na promoção do diálogo entre leitor e autor, não sendo uma mera decodificação de palavras e interpretação textual, pois isto é que fará desenvolver a reflexão do educando.

Portanto, o docente de Literatura não deve encarar a sua prática como simplesmente uma transmissão de textos e conhecimentos de estilos literários, mas como um processo que deve ser sistematizado e organizado, de forma que leve o aluno a uma melhor concepção e visão crítica em relação às produções literárias. Pois, a educação está atrelada à criticidade, de maneira que os educandos devem ser capazes de refletir não somente em sala de aula, mas também em sua vida cotidiana. Ou seja, os textos devem repercutir na vida diária do aluno. Pois, através de uma obra literária, o educando pode ser capaz de pensar sobre sua própria realidade de vida e sobre as problemáticas que sua comunidade enfrenta.

\section{Referências}

BNCC, Base Nacional Curricular Comum. Disponível em: http://basenacionalcomum.mec.gov.br/download-da-bncc. Acesso dia 10 de jan. de 2021.

CANDIDO, A. Textos de intervenção. São Paulo: Duas Cidades, 2002.

COSSON, R. Letramento Literário. 7ed. São Paulo: contexto, 2018.

DIAS, C. O ensino, a leitura e a escrita: sobre conectividade e mobilidade. In: Entremeios Revista de Estudos do Discurso, v. 9, p. 1-14, jul. 2014. Disponível em: http:www.entremeios.inf.br. Acesso em: 07 jan. 2021.

FERNANDES, C. Entre o ver e o ler: gestos de leitura da materialidade visual implicando outros gestos de ensino. In: INDRUSKY, F.; FERREIRA, M. C. L.; FREIRE, Paulo. A 


\section{RCMOS

importância do ato de ler: em três gêneros que se completam. 51. ed. São Paulo: Cortez Editora, 2013.

GIL, A. C. Como elaborar projetos de pesquisa. São Paulo: Atlas, 2002.

GIL, A. C. Métodos e Técnicas de Pesquisa Social. 5. ed. São Paulo: Atlas, 1999.

GIL, A. C. Como elaborar projetos de pesquisa. 5. ed. São Paulo: Atlas, 2010.

KOCH, I. V.; ELIAS, V. M. Ler e Compreender: os sentidos do texto. 3. ed. São Paulo: Contexto, 2010.

LAJOLO, M. Do mundo da leitura para a leitura do mundo. 6. ed. São Paulo: Ática, 2000

LAKATOS, E. M.; MARCONI, M. de A. Fundamentos de metodologia científica. 5. ed. São Paulo: Atlas 2003.

LANES, E. V. Laboratório de Literatura. São Paulo: Estrutura, 1978. 


\title{
O IMPACTO DA REFORMA TRABALHISTA NO TOCANTE AO EMPREGADO DOMÉSTICO
}

\section{THE IMPACT OF LABOR REFORM ON TOUCHING DOMESTIC}

\author{
EMPLOYEES
}

\author{
FABENI, Pricila ${ }^{1}$ \\ PILQUEVITCH, Lincoln Michel²
}

\section{Resumo}

Objetivos: Este estudo tem como objetivo identificar através da Lei Complementar $\mathrm{n}^{\circ}$ 150/2015 os impactos que a Reforma Trabalhista trouxe com a Lei $\mathrm{n}^{\circ} 13.467 / 2017$ para os empregados domésticos. O que se dará na forma de uma revisão de literatura acerca deste ordenamento jurídico e os seus impactos, como base em pesquisa bibliográfica de viés qualitativo e finalidade exploratória. Método: A metodologia utilizada no artigo é de pesquisa bibliográfica sobre o assunto. Este estudo será dividido em tópicos, onde se dá em forma de uma conceituação histórica do trabalho doméstico com a fundamentação da Lei Complementar $\mathrm{n}^{\circ} 150 / 2015$, os impactos trazidos pela Lei $\mathrm{n}^{\circ} 13.467 / 2017$ e por fim, no último tópico serão explorados os direitos que não são aplicados aos empregados domésticos. Resultados: Os resultados demonstram que os novos direitos do trabalhador doméstico e a condição financeira do empregador é um dos elementos determinantes para a formação do vínculo a ser formalizado entre a família e trabalhador doméstico, com consequências sobre a segurança laboral, pois o empregador passará tranquilidade e confiança ao empregado que terá certeza de seus direitos garantidos no momento em que desenvolve suas atividades em seu trabalho. Conclusão: A Reforma Trabalhista poderia ser melhorada, pois a legislação está em constante transformação, passando por evoluções para atender especificamente cada caso exixtente, quando, o trabalhador necessita de apoio judicial.

Palavras-chave: Lei Trabalhista $n .^{\circ}$ 150/2015. Lei $n .^{\circ}$ 13.467/2017. Trabalho doméstico.

\begin{abstract}
Objectives: This study aims to identify through Complementary Law No. 150/2015 the impacts that the Labor Reform brought with Law No. 13,467 / 2017 for domestic employees. What will happen in the form of a literature review about this legal system and its impacts, based on bibliographic research with qualitative bias and exploratory purpose. Method: The methodology used in the article is bibliographic research on the subject. This study will be divided into topics, where it takes the form of a historical concept of domestic work based on Complementary Law No. 150/2015, the impacts brought by Law No. 13,467 / 2017 and finally, in the last topic will be explored rights that are not applied to domestic servants.
\end{abstract}

\footnotetext{
${ }^{1} 1$ Acadêmica do $8^{\circ}$ semestre do Curso de Bacharelado em Direito da Universidade Estadual de Mato GrossoCampus Pontes e Lacerda. E-mail:prifabeni2@gmail.com

${ }^{2}$ Professor Esp. da Universidade Estadual de Mato Grosso-Campus Pontes e Lacerda. E-mail: lincolndireito@hotmail.com
} 
Results: The results show that the new rights of the domestic worker and the financial condition of the employer is one of the determining elements for the formation of the bond to be formalized between the family and the domestic worker, with consequences on job security, as the employer will be at ease and confidence to the employee that he / she will be sure of his / her guaranteed rights the moment he / she develops his / her work activities. Conclusion: The Labor Reform could be improved, as the legislation is constantly changing, undergoing evolutions to specifically address each existing case, when the worker needs judicial support.

Keywords: Labor Law n. ${ }^{\circ}$ 150/2015. Law n. ${ }^{\circ} 13.467$ / 2017. Housework.

\section{Introdução}

A desigualdade entre as pessoas de diferentes classes sociais sempre foi muito evidente. Seus empregos hoje foram conquistados através de muito estudo e qualificação e, de conquistas desde a época da escravidão, onde crianças mulheres e homens, geralmente negros trabalhavam e, tinham como pagamento apenas restos de alimentos deixados pelos seus senhores e, um local para dormir. Era uma época que não havia nenhum registro a dignidade da pessoa humana e também não se tinha direitos e garantias constitucionais.

Em 1830, tem-se o início de um modelo que normaliza o trabalho doméstico e se estabelecia o contrato escrito de prestação de serviço realizados por estrangeiros ou brasileiros, dentro ou fora do império. Já em 1938, os negros, com direito e deveres de cidadãos obtinha seus salários através de seu trabalho realizado. Os que exerciam o trabalho em casas de família receberam o nome de empregados domésticos.

A Lei Aurea foi considerara um marco na história, do Direito do Trabalho no Brasil, pois, mesmo sem uma relação jus trabalhista, mudou a relação de trabalho influente pela escravidão. Época em que antigos escravos se tornaram empregados domésticos com direitos, porém vivendo uma conjuntura semelhante à de antes, necessitavam recorrer aos seus antigos patrões e praticavam os mesmos trabalhos realizados anteriormente.

Neste contexto houve apenas uma camuflagem das peculiaridades dos trabalhos feitos pelos escravos. Desse modo o empregado doméstico passou a consentir um trabalho que não foi legalizado, não adquiriu diretos de um trabalhador e com isso sofreu descriminalização e desvalorização de seu trabalho.

A pesquisa acadêmica traz as diversas inovações inseridas na Consolidação das Leis do Trabalho, por intermédio da Lei $\mathrm{n}^{\circ}$ 13.467/2017, também conhecida como "Reforma Trabalhista", e as mudanças ocorridas na lei n 150/2015 para os empregados domésticos e 
seus novos direitos, um assunto rico e de enorme importância tanto para a sociedade, quanto para o meio jurídico e acadêmico.

O trabalho doméstico é dinâmico e há alguns anos foi reconhecido pelo legislativo, vem passando por transformações e adequações de maneira que o empregado sinta segurança ao ser contratado para realizar seus afazeres, pois passou a possuir garantias de um trabalhador que antes não tinha e, o empregador ao contratar o seu trabalho sentindo-se confortável por ter uma pessoa em sua residência realizando um trabalho com segurança.

Devido a essa condição de empregado e empregador manter boas relações, para que ambos conheçam seus direitos e deveres, faz-se necessário uma análise cuidadosa a respeito da legislação vigente, da realidade vivida, por eles no nosso país, traçando um marco histórico do trabalhador e a evolução da legislação. Assim é possível se sensibilizar e tornar notório o que deu origem a conquista alcançada hoje pelos empregados domésticos.

\section{Fundamentação Teórica}

Ao longo desta revisão de literatura será possível observar que no Brasil, o trabalho doméstico só passou a ser tratado da mesma forma que atividades laborais urbanas e rurais há menos de dez anos, o que faz com que trabalhadores domésticos em outros países possam alcançar um padrão de vida muito maior do que os brasileiros.

De acordo com Rodrigues (2017) isso se deve ao fato de que a CLT criada em 1943, define expressamente em seu sétimo artigo que o seu conteúdo não se aplica ao empregado doméstico, justamente pelo fato de não se tratar de um serviço de natureza econômica. O que significa que foram necessários mais de setenta anos para os empregados domésticos observarem uma mudança significativa no ordenamento jurídico em seu favor.

E com base nessa breve fundamentação teórica acerca da evolução legislativa em torno do tema do trabalho doméstico e conceituação deste trabalho, o próximo passo é discutir em específico a Lei Trabalhista $n .^{\circ} 150 / 2015$ e a Lei n. ${ }^{\circ}$ 13.467/2017. Observando a literatura especializada é possível observar a influência da Convenção da Organização Internacional do Trabalho para a criação da Lei Complementar n ${ }^{\circ}$ 150/2015.

Pois por meio dela o Brasil buscou acompanhar as diretrizes estabelecidas pela convenção. Portanto, Souza (2017) afirma que a Emenda Constitucional $n^{\circ}$ 72/2013, conhecida como a PEC das domésticas, pode ser considerada como um primeiro esboço do que viria a se tornar a Lei Trabalhista $\mathrm{n}^{\circ} 150 / 2015$. 
Em se tratando especificamente da Lei Complementar $n^{\circ} 150 / 2015$, Souza (2017) afirma que a sua criação trouxe uma quantidade significativa de inovações, levando em consideração que a categoria profissional dos empregados domésticos é historicamente injustiçada e inferiorizada.

Conforme Souza (2017), esta lei complementar foi publicada no dia 2 de junho de 2015, e traz como inovações uma definição clara de vínculo empregatício, podendo ser considerado empregado doméstico aquele que presta serviços ao empregador por ao menos três dias na semana, o que traz mais segurança jurídica para a questão. Ao mesmo tempo em que delimita em 8 horas e 44 horas semanais a jornada de trabalho. O que, no entanto, gera um empecilho a mais para o empregador, que agora deve se responsabilizar por fazer o controle de ponto.

Conforme Rodrigues (2017) a Lei Complementar $n^{\circ}$ 150/2015 traz novidades legislativas e revoga o conteúdo do Decreto-Lei n. ${ }^{\circ}$ 5.859/72, também chamado de "Lei dos Domésticos" e entre as suas novidades está a pró́bição no sentido de que menores de 18 anos trabalhem como domésticos e uma definição mais palpável da atividade profissional, trazendo assim maior segurança jurídica, caracterizando-a como a prestação de serviços de forma contínua, subordinada, onerosa e pessoal e de finalidade não lucrativa, a partir de 3 dias por semana.

Em seu estudo, Rodrigues (2017) também afirma que de forma geral os direitos presentes no bojo da Lei Complementar $\mathrm{n}^{\circ} 150 / 2015$ passam a ser os mesmos dos trabalhadores urbanos e rurais em regime CLT. No entanto, devido as particularidades do trabalho doméstico, algumas adaptações se fazem necessárias.

Em decorrência destas inovações, Gomes (2017) defende que Lei Complementar $n^{\circ}$ 150/2015 representou um grande avanço legislativo em matéria de direitos e garantias para os trabalhadores domésticos, pois além de aumentar significativamente os seus direitos trabalhistas, também buscou equipará-los em relação aos dos trabalhadores rurais e urbanos, quebrando assim com séculos de invisibilidade social e injustiça histórica.

Com o passar dos anos, o trabalho vem modificando e necessitando de alterações na lei para corresponder à legislação desatualizada frente às mudanças sociais para responder a interesses da população.

A Consolidação das Leis do Trabalho promulgada em 1940, que já tinha passado por várias mudanças, que se complementam por súmulas e orientações jurisprudências e diversas leis, no entendimento e execução da norma jurídica, passou por uma reforma trabalhista, que 
alterou alguns artigos da Lei $n^{\circ}$ 150/2015, onde algumas das mudanças, já são atendidas pela Lei Complementar 150, que regulariza o empregado doméstico, prevalecendo o que está na Lei complementar.

Também ocorreram mudanças que impactaram grandemente no Emprego do doméstico, pois estas, não são atendidas pela Lei Complementar 150, fazendo-se valer pela Lei $n^{\circ} 13.467 / 2017$. Alterada a CLT, aprovada pelo Decreto Lei $\mathrm{n}^{\circ} 5.452$, de 1 de maio de 1943, e as Leis, nos 6.019 de 03 de janeiro de 1974, que rege o Trabalho Temporário, 8.036, de 11 de maio de 1990, que estrutura o FGTS, e 8.212, de 24 de julho de 1991, que dispõe sobre a Organização da Seguridade Social, a fim de adequar a legislação às novas relações de trabalho.

A Lei $13.467 / 2017$ se materializou a partir da sanção sem vetos feita pelo então presidente Michel Temer no dia 13 de julho de 2017, que até em tão poderia ser reconhecida na forma do Projeto de Lei n. ${ }^{0}$ 6.787/16 criado por iniciativa do Poder Executivo e levado para apreciação da Câmara dos Deputados, momento a partir do qual passou a se chamar PLC 38.

A Lei 13.467/2017 que previa uma vacatio legis de 120 dias a partir de sua publicação a fim de que todos pudessem se adequar a esta nova realidade. O que significou que as alterações passariam a vigorar em meados de novembro.

A Reforma Trabalhista tem sido alvo de acaloradas discussões, devido ao impacto de suas transformações sobre as relações laborais, o que entre outras questões se deve ao fato de que o governo entende que as regras previstas na CLT se encontram ultrapassadas e não abrangem mais o contexto atual, levando em consideração que na década de 40 (quarenta) sequer existia a internet, ficando difícil regulamentar o Home Office e o teletrabalho, por exemplo, ou então os trabalhadores por aplicativo.

O que em seu entendimento também pode ser interpretado como a busca por um equilíbrio basilar de forças dentro do contexto da relação entre capital e trabalho em uma sociedade eminentemente capitalista. Portanto, entende que a reforma trabalhista, na forma da Lei $13.467 / 2017$ pode acabar desembocando em graves convulsões sociais.

\section{Resultados e discussões}

Nesta pesquisa foi tratado da temática relativa ao empregado doméstico, sua relação com as mudanças ocorridas com a Reforma Trabalhista através do advindo da Lei $\mathrm{n} .^{\circ}$ 
13.467/2017. Neste contexto, foi retratado a partir da Lei n. ${ }^{\circ}$ 150/2015 as mudanças ocorridas para os profissionais desta classe trabalhadora, que causaram impactos em seus direitos quanto empregados e ainda, direitos que traz a CLT e não são aplicados a esta categoria de profissionais.

No primeiro instante, verificou-se a evolução histórica do empregado doméstico e suas conquistas legislativas dentro do Direito do Trabalho, mostrando o marco significativo desse desenvolvimento evolutivo, procedimento essencial para compreendermos como desenrolou essa evolução até chegar a Lei n. ${ }^{\circ}$ 150/2015.

Portanto, a pesquisa nos levou a fazer reflexões sobre a relevância quanto ao trabalho doméstico, com o advento desta Lei Complementar, que assegura a essa classe de trabalhadores novos direitos, mas que ainda ocorrem polêmicas a respeito como, o aumento do desemprego ou o crescimento dos trabalhos informais e que para o caso da diarista, onde, o empregador justifica essa informalidade, dizendo que encareceu ter um empregado doméstico em sua residência, pois, ao registrar este, paga-se os encargos trabalhistas. Mas, mesmo antes, com Lei n. ${ }^{\circ}$ 5.859/72 era assegurada o direito ao registro em carteira de trabalho para esta categoria de trabalhador, mas, não era divulgado desta forma e muitos trabalhadores viviam no subemprego.

Portanto, conclui-se neste primeiro instante que os novos direitos do trabalhador doméstico e a condição financeira do empregador é um dos elementos determinantes para a formação do vínculo a ser formalizado entre a família e trabalhador doméstico, com consequências sobre a segurança laboral, pois o empregador passará tranquilidade e confiança ao empregado que terá certeza de seus direitos garantidos no momento em que desenvolve suas atividades em seu trabalho.

É evidente que com a regulamentação do trabalho doméstico muitos saíram prejudicados com a terceirização dos serviços, somado ao momento em que devido aos avanços tecnológicos, cada vez mais a inteligência artificial vai se tornando capaz de realizar atividades humanas.

Por outro lado, a reforma trabalhista permitiu que mais empresas fossem criadas a fim de atender as novas possibilidades de terceirização das atividades-fim, ao mesmo tempo em que novas possibilidades de contrato de trabalho pudessem ser firmadas, bem como atividades profissionais, como as de empregado doméstico finalmente foram regulamentadas.

Sendo que a situação do empregado doméstico no Brasil até o Século XXI se mantinha praticamente a mesma de um século atrás, o que se deve ao fato de que a Consolidação das 
Leis Trabalhistas não interpretava a atividade de empregado doméstico como uma atividade que não possuía fins lucrativos, portanto, não poderia ser regulamentada pela CLT. E assim, a situação ficou até recentemente.

Por outro lado, em um contexto de avanço da pauta neoliberal a impressão que dá é que os criadores da reforma trabalhista não pouparam esforços para estrangular o poder de mobilização dos sindicatos, ao tornar a contribuição sindical algo facultativo, sem querer fazer qualquer juízo de valor aqui, pois não foi o objetivo deste estudo fazer qualquer juízo acerca dos sindicatos.

O caso é que a possibilidade de terceirização da atividade-fim já abre espaço para uma fragmentação das categorias profissionais, cada vez mais atomizadas. Esta discussão poderia se estender por muito mais páginas devido à extensão das leis estudadas aqui.

Portanto, é possível pontuar que a grande inovação da Lei Complementar 150/2015, se dá na forma da proteção jurídica do trabalhador doméstico que ela traz, assim, entende que a Emenda Constitucional n. ${ }^{\circ}$ 72/2013, bem como a Lei Complementar n. ${ }^{\circ}$ 150/2015 cumprem o papel fundamental e constitucional, de desfazer a enorme desigualdade de tratamento observada entre os trabalhadores domésticos e as demais categorias profissionais urbanas ou rurais.

Uma desigualdade que chegou até mesmo a ser reforçada com a criação da CLT, pois seus criadores entendiam que o trabalho doméstico não se encaixava na categoria de trabalhos com finalidade lucrativa, e que, desta forma não deveria ser amparada pela legislação trabalhista.

Em suma as mudanças provocadas pela Reforma Trabalhista são muito amplas e atingem diversos pontos na vida de empregados, além de variadas modificações na seara do processo trabalhista. Assim, foi possível averiguar ao longo do presente texto, algumas mudanças que não terão impacto considerável para os empregados domésticos, ou por já terem sido normatizadas antes pela Lei Complementar $n^{\circ} 150 / 2015$, ou por não terem aplicabilidade prática no vínculo contratual. Outras, diferentes, entretanto, são desafios para os trabalhadores se moldarem na relação de labor específico, como no caso das mudanças com maiores impactos para os empregados doméstico.

Além disso, a Reforma Trabalhista ocorreu para alterar as relações individuais e coletivas de trabalho. Tratamos ao longo da nossa breve explanação teórica dos princípios e dispositivos alterados pela Lei n. ${ }^{\circ}$ 13.467/2017, para que pudéssemos ter a certeza de que a reforma trabalhista veio a modificar as relações individuais e coletivas de trabalho uma vez 
que, consideráveis mudanças normativas chegaram às normas combinadas e às negociações individuais coletivas de trabalho de modo que vários direitos se fexibilizaram e que antes, ficavam mais enrijecidos.

\section{Considerações finais}

A doutrina trabalhista trouxe inovações positivas que já foram abordadas neste trabalho de pesquisa. Temos uma grande controvérsia, em relação à Reforma Trabalhista para com os empregado doméstico, pois o trabalho que o empregado doméstico exerce, não é uma atividade econômica, não visa lucro, se exercesse função de vendas, deixaria de ser doméstico e assim seria registrada como celetista.

Esta posição esta presente no artigo $7^{\circ}$ da CLT que diz que o doméstico esta fora da proteção celetista enquanto, o artigo 19 da Lei Complemetar $n^{\circ} 150 / 2015$, diz que, se houver omissão aplica-se a CLT ao doméstico. Assim, a CLT trouxe as mudanças com a Reforma Trabalhista deixando este profissional mais tranquilo em relação a seus direitos e deveres, passando cada dia reconhecer cada vez mais por meios jurídicos este profissional que tanto apoia os famíliares nos trabalhos que desenvolvem no seu cotidiano.

Após pesquisas e estudos ao empregado doméstico, acredita-se que foi de grande valia o que a Reforma Trabalhista trouxe como, por exemplo, a relação à multa por não assinar a carteira dos trabalhadores domésticos, a demissão a acordada entre empregador e empregado, as atividades particulares não computadas como a hora extra, o reajuste anual de multas entre outros, pois traz a este profissional suas garantias que antes não existia.

Já em relação, por exemplo, ao empregado doméstico ter que pagar perícia judicial se perder a ação trabalhista, mesmo que o empregado tenha obtido justiça gratuita, à terceirização com o emprego doméstico, os benefícios fornecidos ao empregado, entre outros, poderiam ser melhorados, pois, neste sentido, ficou deficiente para o empregado.

Assim, a Reforma Trabalhista poderia ser melhorada, pois a legislação está em constante transformação, passando por evoluções para atender especificamente cada caso existente, quando, o trabalhador necessita de apoio judicial. 


\section{Referências}

BALBINOT, J. H. Empregadas Domésticas e a Promessa de Isonomia: Particularidades da Lei Complementar n. 150/2015 Frente ao Regime Trabalhista Geral. Trabalho de Conclusão de Curso de Graduação, Universidade Federal do Rio Grande do Sul. Faculdade de Direito. Curso de Ciências Jurídicas e Sociais, 2017. Disponível em: https://www.bdm.unb.br/handle/10483/14997. Acesso em: 19 ago. 2020.

BONAVIDES, P. Curso de direito constitucional. 5. ed. São Paulo: Malheiros Ed., 1994.

CARVALHO, F. A reforma trabalhista e a Justiça do Trabalho: breves comentários à Lei 13.467/2017. Revista do Tribunal Regional do Trabalho da $1^{a}$ Região, v. 21, n. 2, p. 43 52, 16 nov. 2017. Disponível em:

https://revista.trt10.jus.br/index.php/revista10/article/view/189. Acesso em: 19 ago. 2020.

CASTRO, M. do P. S. W. de. A concretização da proteção da maternidade no direito do trabalho. São Paulo: Revista LTr. v.69 n. 8. 2005, p.945-967.

COUTINHO, A. R. Poder Punitivo Trabalhista. São Paulo: LTr, 1999.

CREMONESI, A. A discriminação de trabalhadores negros ou pardos e a inversão do ônus da prova em juízo. São Paulo: Revista LTr. v. 69, 2005. p. 1025-1152.

DELGADO, G. M.; DELGADO, G. N. A reforma trabalhista no Brasil. São Paulo. LTR. 2017. Disponível em: https://www.medicina.ufmg.br/nest/wpcontent/uploads/sites/79/2018/07/reformatrabalhista.pdf. Acesso em: 18 out.2020.

FRANÇA, P. H. S. Os direitos trabalhistas dos empregados domésticos: uma análise crítica da Lei Complementar n. 150, 2016. 49 f. Monografia (Bacharelado em Direito). Universidade de Brasília, Brasília, 2016. Disponível em: https://www.bdm.unb.br/handle/10483/14997. Acesso em: 19 ago. 2020.

GARCIA, G. F. B. Reforma trabalhista. 2. ed. Salvador: Juspodivm, 2017. Disponível em: https://www.editorajuspodivm.com.br/. Acesso em: 19 ago. 2020.

GOMES, D. V. A importância da Lei complementar n. 150/2015 para a efetividade da dignidade humana do trabalhador doméstico. Revista do Tribunal Superior do Trabalho, São Paulo, SP, v. 83, n. 1, p. 235-277, jan./mar. 2017. Disponível em: https://juslaboris.tst.jus.br/. Acesso em: 19 ago. 2020.

LIMA, A. L. F. Lei Complementar n. 150/2015: avanços significativos e seus impactos na sociedade. Universidade Federal de Pernambuco - UFPE, 2017. Disponível em: https://repositorio.ufpe.br/handle/123456789/21932. Acesso em: 19 ago. 2020.

LORETO, M. das D. S.; SILVA, D.de F. da; BIFANO, A. C. S. Ensaio da História do Trabalho Doméstico no Brasil: Um trabalho invisível. Cadernos de Direito, Piracicaba, v.17 
n. 32, p. 409-438, jan./jun. 2017. Disponível em: https://www.metodista.br/revistas/revistasunimep/index.php/cd/article/view/3052. Acesso em: 19 ago. 2020.

MARTINS, S. P. Comentários à CLT. 19. ed. São Paulo: Atlas, 2015.

MARTINS, S. P. Direito do Trabalho. 35. ed. SaraivaJur, 2019

MYRRHA, L.; WAJNMAN, S. Características e heterogeneidade do emprego doméstico no Brasil. Revista da Associação Brasileira de Estudos do Trabalho, São Paulo, v. 6, n. 2, p. 109-132, 2007. Disponível em: http://www.abep.org.br. Acesso em: 19 ago. 2020.

PESSOA, Raíssa Moura Jonas. A Lei 13.467/17 (Reforma Trabalhista) e suas implicações na Jornada de Trabalho. Monografia (Graduação) - Universidade Federal da Paraíba, Santa Rita, 2017. Disponível em: https://repositorio.ufpb.br/jspui/handle/123456789/11457. Acesso em: 19 ago. 2020.

RODRIGUES, Bruno Alves. Indução à ruptura da consciência de classe por meio da Lei 13.467/2017. Revista do Tribunal Regional do Trabalho da $3^{\text {a }}$ Região, Belo Horizonte, MG, v. 63, n. 96, p. 227-243, jul./dez. 2017. Disponível em:

https://juslaboris.tst.jus.br/handle/20.500.12178/142143. Acesso em: 19 ago. 2020.

SCHÜTZ, Nathália Chichôrro. Trabalho Doméstico no Brasil: uma perspectiva social, racial, de gênero e as conquistas jurídicas. Orientadora: Norma Sueli Padilha, 2019. Trabalho de Conclusão de Curso (graduação) - Universidade Federal de Santa Catarina, Centro de Ciências Jurídicas, Graduação em Direito, Florianópolis, 2019. Disponível em:

http://repositorio.ufsc.br. Acesso em: 19 ago. 2020.

SEBRAE. Saiba como a Nova Lei Trabalhista impacta os pequenos negócios. 2020. Disponívelem: https://m.sebrae.com.br/sites/PortalSebrae/sebraeaz/saiba-como-a-nova-leitrabalhista-impacta-os-pequenosnegocios,c16a0edf67bef510VgnVCM1000004c00210aRCRD. Acesso em: 19 ago. 2020.

SOUZA, C. P. de. A Evolução dos Direitos Trabalhistas dos Empregados Domésticos no Brasil: Uma Análise da Regulamentação pela Lei Complementar n. 150, 2015. Centro Universitário Toledo. Araçatuba, 2017. Disponível em:

https://servicos.unitoledo.br/repositorio/handle/7574/65. Acesso em: 19 ago. 2020.

TERENSE, B. M. C. Breve análise da lei complementar n.150 de 1 de julho de 2015: Lei das empregadas domésticas e seus aspectos práticos. Revista de Trabalhos Acadêmicos da FAM, v.2, n.1, 2017. Disponível em: http://faculdadedeamericana.com.br/revista/index.php/TCC/article/view/141. Acesso em: 19 ago. 2020 . 


\title{
BARRA LIMPA- NÃO AO LIXO NA CIDADE E NO RIO, RECICLANDO ATITUDES.
}

\section{CLEAN BAR - NO TRASH IN CITY AND RIVER, RECYCLING ATTITUDES.}

\author{
BARROS, Rosilene da Silva ${ }^{1}$ \\ COSTA, Euvânia Dias Ferreira $\mathrm{da}^{2}$ \\ COSTA, Marlene da Paixão ${ }^{3}$ \\ EDJARBAS, José Geraldo ${ }^{4}$ \\ FABENI, Pricila ${ }^{5}$ \\ GALVÃO, Laura Cristina X. S. de M. ${ }^{6}$ \\ NASCIMENTO, Marcia Regina Zotesso do ${ }^{7}$ \\ PERES, Luzia Maria Silva ${ }^{8}$ \\ ROCHA, Sueli Marta ${ }^{9}$ \\ TAVARES, Conceição Aparecida Gonçalves ${ }^{10}$ \\ ZAGO, Marcia Conciane ${ }^{11}$
}

\section{Resumo}

Objetivos: Este estudo apresenta os resultados do projeto Barra Limpa que foi desenvolvido na Escola Estadual Júlio Müller, na cidade de Barra do Bugres-MT. O intuito do projeto foi trazer não só a comunidade da escola como também a sociedade mais próxima do meio ambiente, discutindo sobre a educação ambiental, a reciclagem do lixo e ainda trazendo informações de importante cunho cientifico para que os alunos possam fazer da sua comunidade um local mais saudável promovendo a integração entre as organizações que trabalham diversas dimensões da cidadania, efetivando os direitos de cidadania no cotidiano da população levou às escolas e à comunidade o conhecimento necessário para a construção de cidadania, envolveu diferentes órgãos que asseguraram os direitos e deveres dos indivíduo na sociedade. Metodologia: Realizamos ações concretas como visitas técnicas de estudos em alguns locais como, o Rio Paraguai que é situado em Barra do Bugres-MT, em terrenos baldios e na nossa própria escola, onde, o lixo era depositado inadequadamente. Foi realizadas palestras para orientar corretamente a comunidade escolar sobre vários temas e ainda plantio de mudas. Resultados: Confeccionamos materiais didáticos alternativos usando sucatas,

\footnotetext{
${ }^{1}$ Professora Graduada em Matemática pela UNEMAT. Email: rosi.barros@gmail.com

${ }^{2}$ Professora Graduada em Pedagogia pela UNOPAR Email:euvaniaferreira@gmail.com

${ }^{3}$ Professora Graduada em Pedagogia pela UNOPAR. Email:paixaomarlenecosta@gmail.com

${ }^{4}$ Professor Graduado em Geografia pela UNIFEV. Email:edjarbas-geo@hotmail.com

${ }^{5}$ Professora Graduada em Ciências Biológicas e Química Pela UEM/ IFMT Email: pricilafabeni3@gmail.com

${ }^{6}$ Coordenadores Pedagógicos da Escola Estadual Júlio Barra de Bugres-MT.

Email:juliomullercorrdenacao@gmail.com

${ }^{7}$ Professora Graduada em Física pela UFMT Email:zotesso_nascimento@hotmail.com

8 Diretora da Escola Estadual Júlio Barra de Bugres-MT. Graduada em Sociologia pela UFMT. Email:direcaojuliomuller@gmail.com

${ }^{9}$ Professora Graduada. em Filosofia pela UFMT Email: suelimartarocha@hotmail.com

${ }^{10}$ Professora Graduada em Matemática e Física pela UNESP. Email: conceicaogoncalvestav@gmail.com

${ }^{11}$ Coordenadores Pedagógicos da Escola Estadual Júlio Barra de Bugres-MT.

Email:juliomullercorrdenacao@gmail.com
}

RCMOS - Revista Científica Multidisciplinar O Saber. ISSN: 2675-9128. São Paulo, v. 02, p. 01-10, fev. 2021. 
culminando com uma exposição dos trabalhos, a implantação no ambiente escolar de um projeto piloto de separação do lixo, a organização de uma cartilha educativa. Conclusão: Percebemos com o desenvolvimento do projeto uma grande mudança no comportamento daqueles que não acreditavam que cada um fazendo a sua parte, pode sim fazer mudanças, e ter um meio ambiente mais limpo, saudável para todos os seres que habitam.

Palavras-chave: Educação Ambiental. Meio ambiente. Reciclagem.

\section{Abstract}

Objectives: This study presents the results of the Barra Limpa project that was developed at the Júlio Müller State School, in the city of Barra do Bugres-MT. The aim of the project was to bring not only the school community but also the society closer to the environment, discussing environmental education, recycling of trash and also bringing information of an important scientific nature so that students can make their community a healthier place promoting integration between organizations that work with different dimensions of citizenship, making citizenship rights effective in the daily life of the population, brought schools and the community the knowledge necessary to build citizenship, involved different bodies that ensured the rights and duties of citizens. individual in society. Methodology: We carry out concrete actions such as technical study visits in some places, such as the Paraguay River, which is located in Barra do Bugres-MT, in vacant lots and in our own school, where the garbage was improperly deposited. Lectures were given to correctly orient the school community on water, hygiene methods, public safety. Results: We made alternative teaching materials using scraps, culminating with an exhibition of the works, the implementation in the school environment of a pilot project for the separation of garbage, the organization of an educational booklet. Conclusion: We realized with the development of the project a great change in the behavior of those who did not believe that each one doing their part, can instead make changes, and have a cleaner, healthier environment for all beings that Inhabit.

Keywords: Environmental Education. Environment. Recycling.

\section{Introdução}

A educação ambiental é um processo contínuo no qual os indivíduos e a comunidade tomam consciência de seu ambiente e adquirem: o conhecimento, os valores, as habilidades, as experiências e a determinação que os tornam aptos a agir individual e coletivamente, resolvendo os problemas ambientais presentes e futuros.

Um dos grandes problemas a serem enfrentados pela humanidade, na atualidade, é a questão ambiental, devido à falta de responsabilidade do homem, cujas atitudes impensadas vêm destruindo e comprometendo a vida no planeta. Um dos aspectos a ser ressaltado é o crescimento desordenado do lixo sem o destino adequado, acaba causando grandes transtornos nas cidades ameaçando a vida.

De acordo com os PCNS é preciso que as pessoas saibam como atuar, como adequar práticas e valores, uma vez que o ambiente é também uma construção humana, sujeita a 
determinação de ordem não apenas naturais, mas também sociais.

A situação do lixo precisa ser repensada em nossa cidade, pois não contamos com serviços de coleta seletiva ou empresa que trabalhe com reciclagem. O Lixo é um problema que não para de crescer em todo o mundo, e cada vez mais vem sendo tema principal de debates internacionais e pede para sua solução a participação de todos.

Desde o acúmulo o em locais não apropriados até a forma em como ele é tratado, geram, além do agravo da poluição, consequências urbanas drásticas, tais como alagamentos, doenças, e injustiças sociais. Infelizmente os lixos, tanto doméstico quanto industrial, levam muito tempo para se decompor na natureza e se continuarmos agindo com descaso a esse fato, as consequências serão cada vez piores, a ponto de tornarem-se irreversível.

Tendo em vista que esse problema é antigo da sociedade, alternativas para coleta e reciclagem de lixo já vêm sendo praticadas em grande parte das cidades mais desenvolvidas, que agem focadas na modernização da coleta e senso humanitário, fazendo com o que é considerado lixo para alguns, se torne fonte de renda e subsistência para outros.

É com esse pensamento que surgiu a iniciativa do "PROJETO BARRA LIMPA", de criar um programa com o objetivo de educar, conscientizar e exercitar a cidadania dos nossos alunos e de todos os barrabugrense.

Os princípios gerais da educação ambiental são voltados a sensibilização um processo de alerta, é o primeiro passo para alcançar o pensamento sistêmico; A Compreensão, com conhecimento dos componentes e dos mecanismos que regem os sistemas naturais; A responsabilidade com reconhecimento do ser humano como principal protagonista; A Competência com capacidade de avaliar e agir efetivamente no sistema; A Cidadania para participar ativamente e resgatar direitos e promover uma nova ética capaz de conciliar o ambiente e a sociedade.

Promover a integração entre as organizações que trabalham nas diversas dimensões da cidadania, com o objetivo de ampliar o conhecimento e efetivar a implementação dos direitos de cidadania no cotidiano da população.

Com o intuito de levar às escolas e à comunidade o conhecimento necessário para a construção da cidadania foi envolver diferentes órgãos que asseguram os direitos e deveres de cada indivíduo na sociedade. Entre esses órgãos temos a Polícia Militar, o Corpo de Bombeiros, a Vigilância Sanitária, entre outros.

Foram trabalhados temas relacionados à melhoria da qualidade de vida da população, por exemplo: O lixo (redução, reutilização e reciclagem); o lixo Hospitalar (destinação); a 
água (consumo, desperdício, poluição); as florestas (porque preservá-las); o fogo (prevenção, efeitos negativos ao meio ambiente); os agrotóxicos (riscos para a saúde, danos ambientais); a caça ilegal; sobre o respeito aos animais silvestres e domésticos; as drogas; as IST-Infecções sexualmente transmissíveis; a segurança no trânsito; o respeito ao próximo; a noções de saúde (higiene, prevenção de doenças); a cidadania (direitos do cidadão), entre outros.

\section{Fundamentação Teórica}

"Reciclar" é uma questão de saúde tanto nossa como do meio ambiente, a natureza é que sofre com atitudes impensadas, principalmente as riquezas naturais de nossa cidade de Barra do Bugre, a sacola plástica é uma de nossas grandes preocupações. Ela é composta de plástico um material de baixo valor comercial.

Com a crise econômica as pessoas tentam buscar alternativas para economizar então reutilizam as sacolas plásticas para acondicionar o lixo residencial que além de serem inadequadas para este fim ainda sofrem ataque de animais que perambulam pela cidade a procura de comida espalhando lixo pelas ruas tornando a vista e o cheiro desagradável.

Foi na tentativa de melhorar essa situação que nasceu a ideia do presente projeto, disponibilizar na cidade de Barra do Bugres-MT, uma opção, já existente em outros municípios, mas que infelizmente ainda não tínhamos acesso como à sacola retornável.

Para demonstrar nossa preocupação com o meio ambiente realizamos um desfile apresentando as sacolas de tecido, confeccionadas pelo projeto para a comunidade da Escola Júlio Müller, para que pudéssemos sensibilizar as pessoas para fazer escolhas diferenciadas deixando a comodidade das sacolinhas plásticas e optando por escolhas que ajudam o meio ambiente como as sacolas de tecido, escrevendo uma nova história no futuro.

O lixo é um problema de saúde pública, e o seu crescimento acelerado destrói mais rápido o meio ambiente. $\mathrm{O}$ abandono do lixo em terrenos baldios ou em lixões provoca a multiplicação de ratos, insetos e a proliferação de doenças A paisagem da cidade está sendo comprometida devido à concentração de lixo, tais como: sacolas plásticas, garrafas pet, latas, etc. Tendo em vista que a escola é o espaço social e o local onde o aluno dar sequência ao seu processo de socialização. O que nela se faz se diz e se valoriza representa um exemplo daquilo que a sociedade deseja e aprova.

Comportamentos ambientalmente corretos devem ser aprendidos na prática, no cotidiano da vida escolar, contribuindo para a formação de cidadãos responsáveis. 
Considerando a importância da temática ambiental e a visão integrada do mundo, no tempo e no espaço, a escola busca oferecer meios efetivos para que cada aluno compreenda os fenômenos naturais, as ações humanas e sua consequência para consigo, para sua própria espécie, para os outros seres vivos e o ambiente.

É fundamental que cada aluno desenvolva as suas potencialidades e adote posturas pessoais e comportamentos sociais construtivos, colaborando para a construção de uma sociedade socialmente justa, em um ambiente saudável.

Com os conteúdos ambientais permeando todas as disciplinas do currículo e contextualizados com a realidade da comunidade, a escola ajudará o aluno a perceber a correlação dos fatos e a ter uma visão holística, ou seja, integral do mundo em que vive. Para isso a Educação Ambiental deve ser abordada de forma sistemática e transversal, em todos os níveis de ensino, assegurando a presença da dimensão ambiental de forma interdisciplinar nos currículos das diversas disciplinas e das atividades escolares.

\subsection{Fundamentação teórico/prática do projeto}

Ocorreu por intermédio do estudo de temas geradores que englobaram palestras, oficinas e saídas a campo. Esse processo ofereceu subsídios para que possamos atuar de maneira a englobar toda a comunidade escolar e do bairro na coleta de dados para resgatar a história da área para, enfim, conhecer seu meio e levantar os problemas ambientais como as queimadas um problema grave da cidade de Barra do Bugres, assim, através da cidadania ter a compreensão, a responsabilidade, a sensibilização e a competência.

Esse projeto utilizar a escola como um instrumento de educação continuada para os alunos e para a sociedade, ajudando-os a ter uma mudança comportamental e serem capazes de responsabilizar-se por suas próprias escolhas.

Esse projeto é de grande contribuição para a atuação governamental no que tange a destinação correta dos resíduos sólidos e também para despertar em nossos alunos a consciência de que praticamente todo o lixo pode ser reaproveitado, sendo utilizado na confecção de ricos e criativos materiais didáticos, que servem de instrumentos para enriquecer as aulas, facilitando assim, o processo ensino/aprendizagem.

O lixo é um problema que não para de crescer em todo o mundo, e cada vez mais vem sendo tema principal de debates internacionais e pede para sua solução a participação de todos. Desde o acúmulo do lixo em locais não apropriados até a forma em como ele é tratado, 
geram, além do agravo da poluição, consequências urbanas drásticas, tais como alagamentos, doenças, e injustiças sociais.

Infelizmente os lixos, tanto doméstico quanto industrial, levam muito tempo para se decompor na natureza e se continuarmos agindo com descaso a esse fato, as consequências serão cada vez piores, a ponto de tornarem-se irreversível. Tendo em vista que esse problema é antigo da sociedade, alternativas para coleta e reciclagem de lixo já vêm

sendo praticadas em grande parte das cidades mais desenvolvidas, que agem focadas na modernização da coleta e senso humanitário, fazendo com o que é considerado lixo para alguns, se torne fonte de renda e subsistência para outros. Realizamos também juntamente com os alunos, o plantio de mudas de árvores no pátio da escola que foram doadas por uma empresa e pela prefeitura Municipal.

\section{Resultados e discussões}

O projeto se desenvolveu com o comprometimento de toda a comunidade da Escola Estadual Júlio Müller, onde foi trabalhado com enfoque na reciclagem. A sociedade também abraçou o projeto, foi apresentado aos supermercados e a população barrabugrense as sacolas de tecido que foi bem aceita a todos.

Já quanto a questão ambiental percebemos que a sociedade ainda deixa a desejar, tornando algo um tanto preocupante, pois a falta de conhecimento de muitos os faz ter atitudes que prejudicam o meio ambiente e ao próximo. Mas acreditamos que ainda há possibilidades em mudarmos as atitudes das pessoas.

Consideramos uma ajuda dos alunos para que se faça um elo entre as famílias, com informações tanto para a saúde e o bem estar quanto para a contribuição em um meio ambiente voltado a educação ambiental de qualidade, gerações estas que contribuirá para a distorção conceitual da população mais antiga. Ainda há esperanças em termos um meio ambiente saudável.

O projeto também contou com palestras, exposições sobre temas variados como drogas, IST, noções de saúde, segurança no trânsito, cidadania, respeito ao próximo. Contou com o desenvolvimento de cursos e atividades com enfoque na questão do lixo e das sacolas plásticas, a água tentando sensibilizar a comunidade do problema representado pelos resíduos jogados de forma agressiva na natureza. 


\section{Considerações finais}

Com a evolução a relação homem/ natureza foi deixando sinais de degradação no meio ambiente, pois é do meio ambiente que o homem subtrai o seu sustento e consequentemente produz lixo, desmata e polui todo seu o habitat como rios e lagos.

O projeto "Barra Limpa" trouxe a importância da conscientização para a Comunidade da Escola Estadual Júlio Müller e também a sociedade local, orientando para uma visão mais ampla, onde através de palestras se discutiu muito sobre a importância de se ter uma qualidade ambiental, proporcionando assim uma correlação entre meio ambiente e saúde da população, evitando desde uma queimada, acúmulos de lixo.

Além disso, houve uma preocupação em orientar a população quanto ao descarte correto do lixo. Através da confecção de cartilhas o educando compreendeu e colocou em pratica no momento em que separou o lixo para reciclar em trabalhos que desenvolveram com as sucatas.

Outro ponto de interação importante foi a realização da limpeza na beira do Rio Paraguai, na escola e o plantio de mudas no pátio da escola Percebemos nesses momentos a alegria da Comunidade da Escola Júlio Müller em realizar um trabalho que traz o bem estar social e ambiental.

O ensino e a prática de Educação Ambiental foram trabalhados em todas as disciplinas de forma interdisciplinar, proporcionando maior absorção dos conceitos relacionados ao lixo e ao meio ambiente, colaborando para a formação de um individuo consciente, que coopere com a preservação do meio ambiente.

Diante o exposto, podemos perceber que a Educação Ambiental é o instrumento capaz de transformar ideias, valores e costumes, e é nesta perspectiva que devemos investir observando o ponto de vista que é pela educação ambiental que poderemos conseguir modificar e recuperar o meio ambiente, assim a obrigação de cuidar e preservar é de todos, ou seja, é um dever de toda a sociedade. Pois não é somente ter direito ao meio ambiente ecologicamente equilibrado, é utilizar de estratégias para uma melhoria na qualidade de vida das pessoas.

Para ter um meio ambiente em equilíbrio e sustentável devem-se juntar forças entre Estado e sociedade. Defendemos esta ideia, porque foi visível que quando nós nos unimos em 
nosso projeto "Barra Limpa" onde sociedade abraçou o projeto junto à Comunidade da Escola Júlio Müller os resultados foram positivos.

Portanto, se todos nós nos juntarmos e em prol a proteção do meio ambiente para obtermos uma qualidade de vida com desenvolvimento sustentável, unido a educação ambiental para que, além de nós também as futuras gerações possam usufruir disso.

\section{Referências}

ASSAD, Z. P. Legislação ambiental de Mato Grosso. Cuiabá: Editora de Liz, 2007.

BARBIERI, José Carlos. Desenvolvimento e Meio Ambiente: as estratégias de mudanças da Agenda 21, 3 ed. Petrópolis - RJ, 2000.

BRASIL. Parâmetros Curriculares Nacionais: meio ambiente, saúde. 3. ed. Brasília-DF: Ministério da Educação. Secretaria da Educação Fundamental, 2001.

BRASIL. Constituição da República Federativa do Brasil, de 05 de outubro de 1988. 6. ed. atual.

CARVALHO, I. C.de M. Educação Ambiental: A formação do sujeito ecológico. São Paulo: Cortez, 2004.

CARVALHO, I. C.de M. A invenção ecológica: sentidos e trajetórias da educação ambiental no Brasil. Porto Alegre: Editora da UFRGS, 2001.

DIAS, Genebaldo Freire. Educação ambiental: princípios e práticas. 7.ed. São Paulo: Gaia, 2001 .

GRIPPI, S. Lixo Reciclagem e sua história. 2. ed. Rio de Janeiro, Interciência, 2006.

GRIPPI, S. Reciclagem e sua História. 1. ed. Rio de Janeiro, 2001.

JAPIASSU, H. F. Interdisciplinaridade e patologia do saber. Rio de Janeiro: Imago, 1976.

RASILCHIK, M. Prática de Ensino de Biologia. São Paulo: Editora da Universidade de São Paulo, 2005.

PAIVA, H.N.D.; GONÇALVES, W. Florestas Urbanas: planejamento para melhoria da qualidade de vida. Viçosa: Aprenda Fácil Editora, 2002, v.2.

ROUQUAYROL, M. Z; ALMEIDA FILHO, N. Epidemiologia e saúde. 5. ed. Rio de Janeiro: Medsi, 1999.

VALLE, Cyro Eyer. Qualidade ambiental: como ser competitivo protegendo o meio ambiente. São Paulo: Pioneira, 1995.

RCMOS - Revista Científica Multidisciplinar O Saber. ISSN: 2675-9128. São Paulo, v. 02, p. 01-10, fev. 2021. 
TRAVASSOS, Edson Gomes. A prática da educação ambiental nas escolas. Porto Alegre, RS: Editora Mediação, 2.ed., 2006.

ZUBEN, F. V. Meio Ambiente, Cidadania e Educação. Campinas. Departamento de Multimeios. Unicamp. Tetra Pak Ltda. 1998. 


\title{
A IMPORTÂNCIA DA ASSISTÊNCIA DA ENFERMEIRA OBSTETRA À GESTANTE NO PROCESSO DE PARTURIÇÃO
}

\author{
THE IMPORTANCE OF NURSING ASSISTANCE OBSTETRATES \\ PREGNANT WOMEN IN THE PARTURITION PROCESS
}

\author{
ARAUJO, Sonalia Barros de ${ }^{1}$ \\ CARNEIRO, Eunice Maria Lopes ${ }^{2}$ \\ COSTA, Luciana Alves ${ }^{3}$
}

\section{Resumo}

Objetivos: Descrever a importância da assistência da enfermeira obstetra à gestante no processo de parturição. Metodologia: Utilizou-se de revisão de literatura os dados foram levantados das bases eletrônicas da Literatura Latino-Americana e do Caribe em Ciências da Saúde (LILACS) e Scientific Eletronic Library Online (SCIELO), revistas eletrônicas, google scholar. A gestação é um período em que a mulher passa por transformações biológicas que variam de gestante para gestante e da idade gestacional. Resultados: A enfermeira obstetra é um profissional habilitado para atuar na assistência à mulher durante o processo do parto. $\mathrm{O}$ processo gestacional trata-se de uma experiência de vida saudável que engloba mudanças físicas, sociais e mentais no cotidiano das gestantes e também das pessoas que com elas convivem. Em algumas situações, a gestação pode trazer riscos para o processo saúde-doença da mãe e do bebê através de uma evolução desfavorável da gravidez. Considerando que nem todos os indivíduos têm a mesma probabilidade para adoecer ou morrer, não são todas as gestações que oferecem riscos para a mãe e para a criança. Conclusão: O parto é um evento único, o respeito e a valorização das experiências de cada mulher são fundamentais ao período que envolve o início do trabalho de parto, parto e nascimento, com necessidade de conscientização do profissional que parteja, para a maneira como a qual as parturientes preferem viver esse momento. Neste contexto, a participação da enfermeira obstetra é fundamental, uma vez que a prática de seus cuidados é de suma importância para humanizar a assistência.

Palavras-chave: Cuidados. Enfermeira Obstetriz. Parturiente.

\footnotetext{
Abstract

Objectives: Describe the importance of obstetric nurse assistance to pregnant women in the parturition process. Methods: Literature review was used and data were collected from the

1 Centro Universitário Tocantinense Presidente Antônio Carlos (UNITPAC), Professora do curso de Enfermagem, pós-graduanda em Especialização em Docência Superior, e-mail: sonalia.barros@gmail.com

2 Centro Universitário Tocantinense Presidente Antônio Carlos (UNITPAC), Professora do curso de Enfermagem, pós-graduanda em Especialização em Docência Superior, e-mail: eunice.enzo2014@gmail.com

3 Centro Universitário Tocantinense Presidente Antônio Carlos (UNITPAC), Professora do curso de Enfermagem, pós-graduanda em Especialização em Docência Superior, e-mail: lucianaalves23@hotmail.com RCMOS - Revista Científica Multidisciplinar O Saber. ISSN: 2675-9128. São Paulo, v. 02, n. 2, p. 01-10, fev. 2021.
} 
electronic databases of Latin American and Caribbean Literature in Health Sciences (LILACS) and Scientific Electronic Library Online (SCIELO), electronic magazines, google scholar. Pregnancy is a period in which women undergo biological changes that vary from pregnant woman to pregnant woman and gestational age. Results: The obstetrical nurse is a professional qualified to assist women during the delivery process. The gestational process is a healthy life experience that includes physical, social and mental changes in the daily lives of pregnant women and also those who live with them. In some situations, pregnancy can bring risks to the health-illness process of the mother and baby through an unfavorable evolution of the pregnancy. Considering that not all individuals are equally likely to fall ill or die, not all pregnancies pose risks to the mother and child. Conclusion: Childbirth is a unique event, respect and appreciation for the experiences of each woman are fundamental to the period that involves the beginning of labor, delivery and birth, with the need to raise awareness of the professional who is giving birth to the way in which parturient prefer to live this moment. In this context, the participation of the obstetrical nurse is essential, since the practice of their care is of paramount importance to humanize care.

Keywords: Care. Obstetrical Nurse. Parturient.

\section{Introdução}

De acordo com as Diretrizes Nacionais de Assistência ao Parto Normal, a obstetrícia moderna contribui na melhoria dos indicadores de morbidade e mortalidade materna e perinatais, por outro, permitiu a concretização do modelo que considera a gravidez e o parto como doenças, e não como expressões de saúde. Como consequência, a mulher e o recémnascido são expostos a elevadas taxas de intervenções (BRASIL, 2016).

Em 1996, a Organização Mundial da Saúde (OMS), propôs mudanças na assistência ao parto e nascimento, incluindo a necessidade de resgate do parto como um evento natural, com estímulo para a atuação da enfermeira obstétrica, a utilização de práticas baseadas nas melhores evidências científicas e o acesso às tecnologias apropriadas de atenção ao parto (BRASIL, 2017).

A enfermeira obstetra é um profissional habilitado para atuar na assistência à mulher durante o processo do parto. O processo gestacional trata-se de uma experiência de vida saudável que engloba mudanças físicas, sociais e mentais no cotidiano das gestantes e também das pessoas que com elas convivem. Em algumas situações, a gestação pode trazer riscos para o processo saúde-doença da mãe e do bebê através de uma evolução desfavorável da gravidez (BRASIL, 2001)

A gravidez é uma condição para a sobrevivência da vida humana, sendo indispensável à renovação geracional, e representa o período de formação de um novo ser. Este período da vida da mulher, que se inicia aquando da concepção, se estende por um período de cerca de 40 
semanas, e termina com o parto (COUNCIL, 2012), é um período em que ocorrem alterações profundas no que respeita ao estilo de vida, provocando mudanças não apenas na vida pessoal, mas também na vida do casal e de toda a família. É também uma fase de preparação física e psicológica, para o nascimento e para a Parentalidade (MENDES, 2009).

Considerando que nem todos os indivíduos têm a mesma probabilidade para adoecer ou morrer, não são todas as gestações que oferecem riscos para a mãe e para a criança. $O$ parto é um evento único, o respeito e a valorização das experiências de cada mulher são fundamentais ao período que envolve o início do trabalho de parto, parto e nascimento, com necessidade de conscientização do profissional que parteja, para a maneira como a qual as parturientes preferem viver esse momento (MAGALHÃES, 2006).

A preparação da gestante para o parto, assim como o acompanhamento do desenvolvimento do ciclo gravídico, é extremamente importante para mãe e bebê, pois além de evitar problemas clínicos também pode atuar em nível de tratamento quando necessário (SILVA, 2013).

Utilizou-se de revisão de literatura os dados foram levantados das bases eletrônicas da Literatura Latino-Americana e do Caribe em Ciências da Saúde (LILACS) e Scientific Eletronic Library Online (SCIELO), revistas eletrônicas, google scholar.

\section{Fundamentação teórica}

\subsection{Trabalho de parto}

Com o surgimento da obstetrícia como ciência, o parto normal deixou de ser um evento privativo pertencente à esfera familiar e ao acervo de conhecimento das mulheres, para ser um evento institucionalizado, amparado por inovações tecnológicas. Em consequência, o parto como um evento contextualizado culturalmente foi perdendo a sua essência diante o controle do processo parturitivo e o gerenciamento do corpo feminino, favorecendo a mudança da posição da mulher, de protagonista para colaboradora (MARTINS, 2005).

O trabalho de parto constitui um processo natural e fisiológico, apesar de ser frequentemente relacionado como momento de profunda preocupação para quem o está vivenciando e para quem está ao lado, pois é caracterizado como um momento difícil e doloroso. Independentemente do processo fisiológico, o modo como a mulher e os familiares encaram o trabalho de parto está relacionado com a maneira como foram socializados em 
relação ao processo de parto (FERREIRA, 2004). O parto pode ser tanto um processo naturalmente fisiológico, como profundamente complexo e disfuncional. Para muitas mulheres, o trabalho de parto é um momento de medo, incerteza, excitação e ansiedade, assim como de antecipação.

O diagnóstico de trabalho de parto é um processo dinâmico, e compreende o período que vai desde o início das contrações uterinas regulares, associadas ao apagamento e à dilatação cervical, até a expulsão do concepto e da placenta (FREITAS, et. al, 2016).

A mulher deve, ainda, ser orientada sobre sinais e sintomas de trabalho de parto que podem ser definidos como: presença de contrações uterinas regulares que aumentam progressivamente em frequência e intensidade, que não diminuem ou cessam com o repouso, com frequência a cada três a cinco minutos e duração que varia de 20 a 60 segundos, associadas ao esvaecimento e dilatação do colo uterino, que deve ser avaliada por profissional de saúde. Destaca-se que a perda do tampão mucoso é um sinal premonitório, porém, não é indicativo de trabalho de parto, assim como a rotura das membranas amnióticas, que ocorrem antes do trabalho de parto em 12 a $20 \%$ dos casos (BRASIL, 2001).

\subsection{A atuação da Enfermeira Obstetra}

A presença da enfermeira obstetra durante trabalho de parto incentiva a participação ativa das mulheres oferecendo encorajamento e estímulo durante todo processo. Acreditouse, quando as mulheres superaram o medo da dor e adquiriram força, em que seu papel na cena do parto é de protagonista, conforme um dos princípios do paradigma humanizado de assistência ao parto. (VIEIRA et. al, 2012)

A enfermeira obstetra tem se mostrado uma profissional com cuidado diferenciado, pois possui postura delicada, respeita a feminilidade da parturiente, transmite segurança, confere autonomia à mulher, permite a expressão da dor e proporciona bem-estar físico e emocional, criando vínculo e sendo valorizada pelas gestantes e seus acompanhantes. (FREIRE et. al, 2017)

Atualmente, a Organização Mundial da Saúde (OMS) e o Ministério da Saúde brasileiro têm recomendado maior participação da Enfermagem Obstétrica para o aprimoramento da assistência ao parto normal e para a diminuição das taxas de cesariana, considerando esta categoria profissional a mais adequada para dar assistência à gestação e ao 
parto normal, com melhor custo, efetividade e segurança, avaliando riscos e detectando precocemente possíveis intercorrências (CAUS et. al, 2012).

\subsection{A assistência durante o trabalho de parto}

Para assumir esse trabalho, a enfermeira deve ser especialista em obstetrícia, formação que lhe dará suporte para assumir condutas indicadas para a execução do parto sem distorcias, conforme resolução que regulamenta o exercício profissional. A entrada da enfermagem obstétrica neste espaço de assistência, ocupado pelos médicos obstetras, tem provocado embates entre estas categorias, dificultando a implantação da política de humanização (OLIVEIRA, 2015).

A enfermeira obstetra deve seguir um modelo de assistência que busque resgatar valores como o protagonismo, a individualidade, a privacidade e a autonomia da mulher, objetivando a promoção de partos saudáveis, eliminando intervenções desnecessárias e oferecendo outras comprovadamente benéficas.

Uma forma de alívio da dor e do sofrimento das mulheres durante o parto é a aplicação dos conceitos de humanização, por meio dos quais fica estabelecido que essas mulheres têm assegurados seus direitos sobre o próprio corpo, podendo optar pelo local, como na banheira, chuveiro, na cama, em pé, deitadas, de cócoras, entre outras. (FUGITA; SHIMO, 2014)

Além disso, essas mulheres têm direito a um acompanhante, visando aumentar a sensação de cuidado e eliminar a solidão vivida por muitas delas. É preciso considerar, em todas as situações, que o parto se trata de um momento marcante na vida das mulheres e, assim, deve ser conduzido com respeito, integridade e de forma digna, para que não seja associado com dor, sofrimento, humilhação e desrespeito. Essa profissional deve estar alerta às queixas e outras manifestações que possam indicar algum tipo de intercorrência, informando a gestante sobre sua evolução no trabalho de parto e sugerindo-lhe condutas a serem tomadas para tornar o momento mais agradável (BRASIL, 2001)

Tem-se a ideia de que a enfermagem deixa a desejar, quanto ao seu papel, visto que, a cliente se encontra em contato diretamente com a enfermagem no pré-natal e pós-parto, assim, fica notória a necessidade de maior envolvimento desse profissional em saúde.

Humanizar o parto não significa apenas fazer o parto normal, realizar ou não procedimentos, e sim tornar a mulher protagonista desse momento e não a tornar apenas 
expectadora, dando-lhe liberdade de escolha nos processos decisórios (SILVA e SILVA, 2013).

O parto humanizado inclui o respeito ao processo fisiológico e à dinâmica de cada nascimento, nos quais as intervenções devem ser cuidadosas, evitando os excessos e utilizando os recursos tecnológicos disponíveis (NAGAHAMA, SANTIAGO, 2011)

Os cuidados de enfermagem centram-se na avaliação e apoio à mulher e à família durante o processo de trabalho de parto e parto, de forma a garantir os melhores resultados possíveis para todos os envolventes. É fundamental envolver a parturiente como parceira na formulação de um plano de cuidado, o que irá permitir a sua participação no nascimento do filho e reforçar a sua autoestima e nível de satisfação (VEZO, CORONEL, ROSÁRIO, 2013).

A formação do enfermeiro voltada para o cuidado humano contribui para criar as disposições profissionais que geram práticas humanizadas pautadas no respeito e nas decisões compartilhadas. Somado a isto, os cursos de especialização em enfermagem obstétrica muito têm contribuído para agregar ao diploma de enfermeiro um capital institucionalizado (título de enfermeira obstétrica através do certificado de especialista) que legitima o discurso autorizado da enfermeira no campo obstétrico, no contexto da humanização, o que lhe confere maior autonomia e poder (WINCK, BRUGGEMANN, 2010)

A atuação dos enfermeiros obstétricos é baseada em técnicas não medicamentosas, como orientar a postura e a mobilidade adequada à parturiente influenciando no alívio da dor e no estímulo do trabalho de parto evitando o uso de analgésicos e ocitocina respectivamente. Essa atitude permite uma melhora na evolução da dilatação, diminuindo a duração da fase ativa. (SANTOS et. al, 2012)

A inserção de um profisssional não médico na assistência a parturiente concede autonomia para prosseguir com o trabalho de parto fora dos centros cirúrgicos, tendo a segurança de um ambiente hospitalar e o acolhimento de um ambiente domiciliar, utilizandose de medidas alternativas, não invasivas e livres de fármacos.

É imprescindível para a implementação do parto humanizado nas instituições hospitalares que sejam criados protocolos e treinamentos para os profissionais que vivenciam este método, tendo uma filosofia mais humanizada.

É importante lembrar que o parto humanizado não tem que ser necessariamente vaginal, porque a cesariana também é válida quando bem indicada, diferentemente da cirurgia planejada, que apresenta riscos para mãe e filho. O nascimento cirúrgico deve ser feito com 
respeito, razão suficiente para a equipe médica, durante os procedimentos, não conversar sobre assuntos desnecessários e fúteis (SESCATO, 2008).

Os enfermeiros receberam seu espaço profissional de forma ética e legal apoiada pela resolução do MS/COFEN223/99 que dispõe sobre a atuação de enfermeiros na assistência a mulher no ciclo gravídico puerperal. Passando a ser de sua competência a realização do parto normal sem distocia, à assistência à gestante, as parturientes e as puérperas, o acompanhamento da evolução do trabalho departo, entre outros.

A atuação dos enfermeiros obstétricos é baseada em técnicas não medicamentosas, como orientar a postura e a mobilidade adequada à parturiente influenciando no alívio da dor e no estímulo do trabalho de parto evitando o uso de analgésicos e ocitocina respectivamente (BARROS; SILVA, 2004).

\section{Considerações finais}

Conclui-se que, o quanto é importante a enfermeira obstetra durante parto, a humanização da assistência ao pré-parto, através da sua inclusão na assistência. Pois a inserção de um profissional não médico na assistência a parturiente concede autonomia para prosseguir com o trabalho de parto fora dos centros cirúrgicos, tendo a segurança de um ambiente hospitalar e o acolhimento de um ambiente domiciliar, utilizando-se de medidas alternativas, não invasivas e livres de fármacos.

A enfermeira obstetra está apto a compreender a dimensão humana do cuidado e participar ativamente nas transformações do cuidado materno e perinatal, tornando os recursos importantes no cuidado a mulher durante a gestação, parto e puerpério.

\section{Referências}

BARROS, L. M.; SILVA, R. M. da. Atuação da enfermeira na assistência à mulher no processo de parturição. Texto contexto - enferm., Florianópolis, v. 13, n. 3, p. 369-375, set. 2004. Disponível em:

http://www.scielo.br/scielo.php?script=sci_arttext\&pid=S010407072004000300006\&lng=en

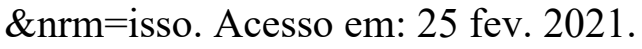

BRASIL. Ministério da Saúde. Secretaria de Políticos de Saúde. Área Técnica de Saúde da Mulher. Parto, aborto e puerpério: assistência humanizada à mulher/ Ministério da Saúde, Secretaria de Políticas de Saúde, Área Técnica da Mulher. - Brasília: Ministério da Saúde, 2001. Disponível em: https://bvsms.saude.gov.br/bvs/publicacoes/cd04_13.pdf. Acesso em: 25 fev. 2021. 
BRASIL. Ministério da Saúde. Ministério da Saúde, Secretaria de Ciência, Tecnologia e Insumos Estratégicos, Departamento de Gestão e Incorporação de Tecnologias em Saúde. Diretrizes nacionais de assistência ao parto normal. Brasília: Ministério da Saúde. 2016. Disponível em: http://biblioteca.cofen.gov.br/wp-content/uploads/2016/10/DiretrizNacional- de-Assist\%C3\%AAncia-ao-Parto-Normal.pdf. Acesso em: 25 fev. 2021.

BRASIL. Ministério da Saúde, Secretaria de Ciência, Tecnologia e Insumos Estratégicos, Departamento de Gestão e Incorporação de Tecnologias em Saúde. Diretrizes nacionais de assistência ao parto normal. Brasília: Ministério da Saúde; 2017. Disponível em: http://bvsms.saude.gov.br/bvs/publicacoes/diretrizes_nacionais_assistencia _parto_normal.pdf. Acesso em: 25 fev. 2021.

CAUS, E. C. M, SANTOS, E. K. A, NASSIF, A. A, MONTICELLI, M. O processo de parir assistido pela enfermeira obstétrica no contexto hospitalar: significados para as parturientes. Esc. Anna Nery [Internet]. 2012, mar; v. 16, n. 1, p. 34-40. Disponível em: http://www.scielo.br/pdf/ean/v16n1/v16n1a 05.pdf. Acesso em: 25 fev. 2021.

COUNCIL AHMA. Clinical Practice Guidelines: Antenatal Care - Module I. Canberra: Australian Government Department of Health and Ageing; 2012

FERREIRA P. J. O. Cuidando profissionalmente do ser humano em vigência de dor: uma abordagem compreensiva. In: CHAVES LD, LEÃO ER, editoras. Dor: $5^{\circ}$ sinal vital: reflexões e intervenções de enfermagem. Curitiba: Editora Maio; 2004. p.11-9.

FREIRE H. S. S, CAMPOS F. C, CASTRO R. C. M. B et. al, Parto normal assistido por enfermeira: experiência e satisfação de puérperas. Rev enferm UFPE on line., Recife, v. 11, n. 6, p. 2357-67, jun., 2017.

FREITAS, et. al, Rotinas em Ginecologia, 7. edição - Porto Alegre: Artmed, 2016.

FUJITA, J. A. L. M.; SHIMO, A. K. K. Parto humanizado: experiências no Sistema Único de Saúde. Rev. Min. Enferm., Belo Horizonte, v.18, n. 4, p. 1011-1015, out./dez. 2014.

MAGALHÃES, D. R. B. et. al, Assistências pré-concepcional e pré-natal. In: ALVES FILHO, N. et. al, (Ed.). Perinatologia básica. 3. ed. Rio de Janeiro: Guanabara Koogan, 2006. p. 37- 51.

MARTINS A. P. V. A ciência dos partos: visões do corpo feminino na constituição da obstetrícia científica no século XIX. Rev Estud Fem. 2005, set./dez., v. 13, n. 3, p. 645-65.

MENDES I. M. Ajustamento materno e paterno: experiências vivenciadas pelos pais no pós parto. Coimbra: Mar da Palavra; 2009

NAGAHAMA, E. E. I.; SANTIAGO, S. M. Parto humanizado e tipo de parto: avaliação da assistência oferecida pelo Sistema Único de Saúde em uma cidade do sul do Brasil. Rev.

Bras. Saude Mater. Infant., Recife, v. 11, n. 4, p. 415-425, dez. 2011. Disponível em: http://www.scielo.br/scielo.php?script=sci_arttext\&pid=S1519-

$38292011000400008 \& \operatorname{lng}=\mathrm{en} \& n \mathrm{~mm}=$ isso. Acesso em: 25 fev. 2021. 
OLIVEIRA, M. M. Sensibilização dos gestores e obstetras de uma maternidade do município de Aracaju para a inserção do enfermeiro obstetra na equipe multidisciplinar da sala de parto. Monografia, Aracajú, 2015. Disponível em: https://repositorio.ufmg.br/bitstream/1843/31847/1/MANUELLE\%20MENEZES\%20DE\%2 0OLIVEIRA\%20UFMG.pdf. Acesso em: 25 fev. 2021.

SANTOS, G. S; SOUSA, J. L. O; ALMEIDA, L. S; GUSMÃO, M. H. A importância do enfermeiro no atendimento humanizado no pré-parto. Revista Diálogos \& Ciência. Faculdade de Tecnologia e Ciência (FTC). Salvador - BA, Brasil, 2012. Disponível em http://dialogos.ftc.br/index.php?option=com_content\&task=328. Acesso em: 25 fev. 2021.

SESCATO, A. C, SOUSA, S. R. S. K, WALL, M. L. Os cuidados não-farmacológicos para alívio da dor no trabalho de parto: Orientações da equipe de enfermagem. Cogitare Enferm. 2008, v. 4, n. 13, p. 585-90.

SILVA, E. A. T. da. Gestação e preparo para o parto: programas de intervenção. O Mundo da Saúde, São Paulo - 2013, v. 37, n. 2, p. 208-215. Disponível em: http://www.saocamilosp.br/pdf/mundo_saude/102/10.pdf. Acesso em: 25 fev. 2021.

SILVA, R. S.; SILVA, M. J. P. Enfermagem e os Cuidados Paliativos. In: SILVA, R. S.; AMARAL, J. B.; MALAGUTTI, W. Enfermagem em Cuidados Paliativos: Cuidando para uma boa morte. 1. ed. São Paulo: Editora Martinari, 2013.

VEZO, G. M. S.; CORONEL, L. M.; ROSÁRIO, M. S. O. Assistência Humanizada de Enfermagem no Trabalho de Parto. Monografia, Escola Superior de Saúde, Mindelo, Cabo Verde, 2013.

VIEIRA B. D. G, MOURA M. A. V, ALVES V. A, RODRIGUES D. P. A prática dos enfermeiros obstetras egressos da especialização da escola de enfermagem Anna Nery. Rev. enferm. UERJ, Rio de Janeiro, 2012 dez; v. 20 (esp1), p. 579-84.

WINCK, D. R.; BRUGGEMANN, O. M. Responsabilidade legal do enfermeiro em obstetrícia. Rev. bras. enferm., Brasília, v. 63, n. 3, p. 464-469, jun. 2010. Disponível em http://www.scielo.br/scielo.php?script=sci_arttext\&pid=S0034-

$71672010000300019 \& \operatorname{lng}=\mathrm{en} \& \mathrm{nrm}=$ iso. Acesso em: 25 fev. 2021. 


\title{
DEFICIÊNCIAS MÚLTIPLAS E INTELECTUAIS
}

\section{MULTIPLE AND INTELLECTUAL DISABILITIES}

\author{
NOGUEIRA, Waldenice Ramos ${ }^{1}$ \\ GUIMAR ÃES, Nara Miranda²
}

\section{Resumo}

Objetivo: Este estudo tem por objetivo geral abordar o conceito de deficiente intelectual focando especificamente em: a) determinar como o diagnóstico da deficiência intelectual acontece e b) dissertar acerca das características da deficiência intelectual. A Deficiência intelectual é compreendida como uma menor capacidade de compreender, aprender e aplicar informações e tarefas novas ou complexas. Pessoas com deficiência intelectual têm um funcionamento mental abaixo da média esperada para a idade, o que provoca um atraso na aprendizagem e no desenvolvimento desses indivíduos. Orientar os pais e irmãos a reconhecerem as dificuldades e a lidar com seus filhos é fundamental nesse processo. Resultados: $\mathrm{O}$ estudo revelou a complexidade do processo de inclusão vivido pelas escolas, particularmente no que se refere ao currículo escolar e as práticas pedagógicas para o ensino e aprendizagem dos alunos com deficiência intelectual. Verificou-se que um dos maiores obstáculos para atender adequadamente esses alunos em salas de aula paira na falta de preparo dos professores. Conclusão: Pode-se concluir que a escola atua como elemento básico do processo de autonomia e integração social das pessoas com deficiências múltiplas ou intelectual.

Palavras-chave: Deficiência múltipla e Intelectual. Inclusão Social. Educação Inclusiva.

\begin{abstract}
Objective: This study has the general objective of addressing the concept of intellectual disability with a specific focus on: a) determining how the diagnosis of intellectual disability happens and b) talking about the characteristics of intellectual disability. Intellectual disability is understood as a lesser capacity to understand, learn and apply new or complex information and tasks. People with intellectual disabilities have a mental functioning below the average expected for their age, which causes a delay in the learning and development of these individuals. Guiding parents and siblings to recognize the difficulties and deal with their children is essential in this process. Results: The study revealed the complexity of the inclusion process experienced by schools, particularly with regard to the school curriculum and pedagogical practices for teaching and learning students with intellectual disabilities. It was found that one of the biggest obstacles to adequately assist these students in classrooms is due to the lack of preparation of teachers. Conclusion: It can be concluded that the school acts as a basic element of the process of autonomy and social integration of people with multiple or intellectual disabilities.
\end{abstract}

Keywords: Multiple and Intellectual Disability. Social inclusion. Inclusive education.

\footnotetext{
${ }^{1}$ Pedagogia. Grupo Educacional Faveni. E-mail: wal_promoter@hotmail.com

${ }^{2}$ Universidade Estadual de São Paulo - Unesp - Campus de Guaratinguetá
} 


\section{Introdução}

$\mathrm{Na}$ Antiguidade os deficientes intelectuais eram abandonados ou assassinados; na idade média foram considerados filhos de satanás, sendo queimados em fogueiras. Durante o Cristianismo foram protegidos como inocentes de Deus já que apresentavam inocência e pureza (CARVALHO, 2004).

Diante do exposto, a doutrina cristã pode trazer demasiadas melhorias em relação ao tratamento proporcionado as pessoas com deficiência, a sociedade da época começou a ter melhores perspectivas sobre elas e consequentemente passaram a aceita-las melhor, mas ainda assim mantendo essas pessoas longe da inserção social. Pessoas com deficiência já não eram vistas como "aberrações" e mesmo ainda descriminadas, passaram a ser ajudadas e solidarizadas por uma minoria (SÁNCHEZ, 2008).

Após esse conceito cristão e o temor à Deus, ao longo da história pessoas com deficiência têm sido estigmatizadas por inúmeros conceitos negativos que foram resistindo com o passar dos séculos, pois era mais fácil se ater as barreiras e as aparências do que as habilidade e capacidades de tais indivíduos. A organização da sociedade, desde seus primórdios, sempre considerou os portadores de deficiência como inabilitados, segregando-os e privando-os de liberdade, esses indivíduos sempre foram alvo de atitudes preconceituosas e ações malevolentes (CARVALHO, 2004).

Desde o surgimento da humanidade que a deficiência é uma questão a ser refletida, pois para cada época, os contextos histórico e social se mostram inerentes ao comportamento que as pessoas tinham frente aos deficientes, por se tratar de um assunto desconhecido resultou em misconcepções e exclusão, além de questionamentos que levaram a considerar as pessoas com deficiência como ignorantes, maldosas e preconceituosas, somente a partir do século XIX é que passaram a ser considerados hábeis de serem educados (ALVES; GOTTI, 2006).

Somente em 13 de dezembro de 1975, que os deficientes passaram a ter seus direitos estabelecidos por lei, conforme o artigo $4^{\circ}$ da declaração dos direitos dos deficientes aprovados pela ONU, lê-se que: "O deficiente tem os mesmos direitos civis e políticos dos demais seres humanos". Na história da humanidade, a deficiência sempre se fez presente das mais diversas formas: preconceituosa, omissa, escondida, ignorada, repreendida, julgada, condenada, 
parcialmente aceita, ou seja, de uma maneira ou de outra a deficiência sempre fez parte da história do homem, estando presente em suas concepções e preocupações, seja no sentindo de aceitação ou de negação" (BATISTA; MANTOAN, 2007).

O que se pode perceber atualmente é que mesmo com os avanços relevantes, no que diz respeito as questões sociais, políticas e legais, os indivíduos portadores de deficiência permanecem à margem do corpo social, sendo tidos como sendo inaptos, ineficientes e ainda popularmente denominados de pobrezinhos, coitadinhos e entre tanto outros adjetivos de inferioridade (ROSSATO; LEONARDO, 2011). Dessa maneira, começa-se um trabalho de conscientização global na sociedade com o intuito de incluir e integra o deficiente intelectual, de modo que o mesmo desenvolva autonomia e capacidade de socialização para exercer uma ou mais atividades da vida diária (SÁNCHEZ, 2008).

Sendo assim, essa pesquisa se justifica por trazer importantes implicações sobre o assunto tratado, uma vez que a deficiência intelectual não é um assunto abordado com frequência. $\mathrm{O}$ presente estudo tem por objetivo geral abordar o conceito de deficiente intelectual e como objetivos específicos: a) determinar como o diagnóstico da deficiência intelectual acontece e b) dissertar acerca das características da deficiência intelectual.

Adotou-se o método descritivo por meio de revisão bibliográfica, com abordagem qualitativa, conforme definido por Shank (2002 p. 5) como sendo "uma forma de investigação empírica sistemática sobre o significado".

\section{Fundamentação Teórica}

A maior conquista da UNESCO na área da deficiência foi, sem dúvida, a Conferência de Salamanca, na Espanha, de 1994 que resultou na Declaração de Acompanhamento e Quadro de Ação. A Inclusion International declarou explicitamente que os Objetivos de Desenvolvimento do Milênio não podem ser cumpridos até 2015 a menos que as crianças com deficiência sejam incluídas na educação.

Os oitenta e oito (NT - hoje já são 103) países que já ratificaram a Convenção da ONU sobre os Direitos das Pessoas com Deficiência estão agora sob a obrigação legal de criar ambientes de educação inclusiva para crianças com deficiência (artigo 24) e enviar relatório sobre o seu 
progresso para o Alto Comissariado das Nações em Direitos Humanos. Cabe agora às sociedades dos países membros assegurarem que sejam tomadas medidas para garantir que todos, sem exceção, sejam incluídos. Na verdade, o processo de inclusão está muito além da simples inserção dos alunos com deficiência no âmbito escolar regular ou na retenção de vagas destinadas para esses indivíduos em concursos públicos e estabelecimentos comerciais (ALVES; GOTTI, 2006).

Faz-se necessária uma transformação na estruturação do atual corpo social, na direção da organização de uma sociedade que esteja realmente apta a atender os reais interesses de todos os indivíduos sem fazer qualquer discriminação. Assim, a luta pela inclusão social deve não ser apenas uma responsabilidade individual, mas coletiva.

Analisando historicamente a etiologia da Deficiência Intelectual, constata-se que embora muitas pesquisas já tenham sido realizadas, essa deficiência ainda é motivo de impasse para muitos educadores devido ao alto grau de complexidade desse tipo de atendimento.

Com a Política de Inclusão, o termo Deficiência Mental foi substituído por Deficiência Intelectual (SÁNCHEZ, 2008). A justificativa dessa mudança foi que, no correr da história, a Deficiência intelectual, foi confundida com Doença Mental, o que até hoje, algumas pessoas, por preconceito ou por falta de informação, ainda confundem os termos. Esse conceito ou falta de informação desenvolvida prejudicam a inclusão e segundo Paulo Freire "A inclusão acontece quando se aprende com as diferenças e não as com as igualdades”, porém a capacitação do atendimento educacional está diretamente ligada ao ambiente escolar e a equipe docente que recebe o aluno.

O trabalho de parceria com a direção escolar, equipe docente e o profissional da Educação Especial tem o intuito de elaborar metodologias e preparar o aluno com deficiência para um ensino adaptado que potencialize suas capacidades, e que desenvolva maneiras de intervenção a fim de promover um ensino cooperativo, inclusivo e integrado para que este aluno tenha capacidade e autonomia para exercer uma ou mais atividades cotidianas (BATISTA; MANTOAN, 2007). Como incluir o aluno deficiente intelectual em uma turma de ensino regular? Segundo Mantoan (1997, p.15)

A escola se entupiu do formalismo da racionalidade e cindiram-se em modalidades de ensino, tipos de serviço, grades curriculares, burocracia. Uma ruptura de base em sua estrutura organizacional, como propõe a inclusão, é uma saída para que a escola possa fluir, novamente, espalhando sua ação formadora por todos os que dela participam. A 
inclusão, portanto, implica mudança desse atual paradigma educacional, para que se encaixe no mapa da educação escolar que estamos retraçando.

A inclusão exige que o conservadorismo seja deixado de lado e que as necessidades de todos os alunos sejam ponderadas e adaptadas de maneira que estes sejam integrados no ambiente escolar, fazendo-se necessário um trabalho e atendimento educacional sistematizado.

A deficiência intelectual ou mental sempre esteve atrelada a ideia de incapacidade e improdutividade, ou seja, ligada a uma imagem negativa das pessoas que compõem esse grupo. Várias áreas do conhecimento científico têm se dedicado à pesquisa com o objetivo de estabelecer um conceito único que defina essa deficiência (ROSSATO; LEONARDO, 2011).

Define-se que deficiência intelectual corresponde a presença de déficits cognitivos concomitantes ao funcionamento adaptativo, em pelo menos duas das seguintes áreas: comunicação, cuidados pessoais, vida doméstica, habilidades sociais / interpessoais, uso de recursos comunitários, independência, habilidades acadêmicas, trabalho, lazer, saúde e segurança.

Sendo que, a mesma, deve ser detectada antes dos 18 anos de idade. Anamnese consiste no histórico de todos os sintomas narrados pelo aluno sobre determinado caso de como se sente de forma global em diferentes ambientes. Também pode ser considerada uma lembrança incompleta ou a reminiscência de uma recordação. Estes relatos são vitais sendo um dos pontos mais importantes do diagnóstico (BATISTA; ENUMO, 2004).

É através dela que podemos buscar as raízes que impedem o aluno de progredir no processo de aprendizagem. A busca da reconstrução do passado e da vida presente nos dará Sustentação para um trabalho seguro e efetivo. Conforme Paim (1985 p. 43-45), “A família é o ponto principal, pois é ela quem, nos fornecerá dados imprescindíveis sobre a vida do aluno".

Considerando que todo sujeito é singular em suas características, como desafio surge à prática pedagógica objeto de estudo que respeita e considera as diferenças atuando de maneira interventora. Tal intervenção se faz necessária na evolução, e inclusão contínua dos indivíduos que apresentem transtornos de prejuízo na interação social e intelectual com seus pares (RIBEIRO, 2009). A Deficiência intelectual é uma menor capacidade de compreender, aprender e aplicar informações e tarefas novas ou complexas. Pessoas com deficiência intelectual têm um funcionamento mental abaixo da média esperada para a idade, o que provoca um atraso na aprendizagem e no desenvolvimento desses indivíduos. É necessário orientar os pais e irmãos a 
reconhecerem as dificuldades e a lidar com seus filhos, ensinando-lhes técnicas de interação com a criança e provendo informações sobre suas dificuldades de modo a facilitar a convivência e tornando o ambiente saudável para a criança. Além disso, buscar formas de atendimento que garantam a inclusão de qualidade dos Deficientes Intelectuais na rede de ensino regular (CASTRO; ALMEIDA; FERREIRA, 2010).

O diagnóstico é vinculado a diversos fatores: biomédicos, etológicos, comportamentos sociais e educacionais e a cargo de uma equipe especializada: médicos, psicológicos clínicos, professores da Educação Especial com especialização na área; profissionais esses habilitados que possam determinar a causa e um tratamento. Todavia, um dos maiores desafios é estabelecer a origem e a causa.

Pesquisas afirmam que em até 50\% dos casos não é possível determinar exatamente a causa. No entanto alguns fatores podem contribuir para que a deficiência seja desenvolvida, chamados de gatilho. Dados da Organização Mundial de Saúde (OMS) mostram que há 322 milhões de pessoas atualmente sofrendo algum tipo de transtorno mental.

- Fatores biomédicos: processos biológicos

- Fatores ambientais: criança maltratada, violentada, abusada, negligenciada.

- Fatores educacionais: não atendimento de apoio e suporte que certas crianças necessitam para o desenvolvimento social, intelectual e pessoal.

- Fatores sociais: interação familiar e social.

Os transtornos mentais implicam alterações no comportamento, na emoção e no sistema cognitivo do indivíduo, na maneira que a pessoa passa a não perceber e conhecer a realidade que a cerca.

Existem mais de 200 tipos de transtorno mentais, que foram classificados em 17 categorias, divididos em quatro grupos: Transtornos Psicóticos (alucinações), Transtornos Neuróticos (a pessoa permanece consciente, mas sofre disfunções como a fobia, por exemplo), Transtornos Orgânicos (doenças orgânicas e alterações cerebrais podem causar os transtornos mentais) e, por fim, os Transtornos Funcionais (aqueles em que não se consegue identificar a causa) (MANTOAN, 2006).

No entanto nenhuns desses fatores provocam a deficiência intelectual exclusivamente, mas definem situações de risco em que a criança pode ter sido colocada. A situação de risco é 
responsável pela redução do desenvolvimento cognitivo causando prejuízos nas funções cognitivas e em outras habilidades que são responsáveis pelo desenvolvimento do cérebro. Para iniciar um atendimento ou trabalho sistematizado é conveniente iniciarmos uma avaliação multidisciplinar e por um relato cronológico detalhado do desenvolvimento, anteriormente ao diagnóstico até a presente data, pois é embasado neste relato e estudos direcionados saber como atuar facilitando e adaptando o currículo para melhor compreensão do aluno com limitações de aprendizagem (DIAS, 2010).

É importante registrar que a teoria Vigotskiana é defendida por muitos estudiosos e profissionais da educação, porque entende-se que o desenvolvimento do aluno com deficiência intelectual não é determinado apenas pelas condições orgânicas ou pelo meio próximo, mas primordialmente pelas possibilidades oferecidas pela escola e pela mediação do professor, que através de uma ação intencionalmente planejada dos conteúdos científicos historicamente construídos, tornará possível o desenvolvimento intelectual do aluno (PALANGANA, 2001).

Normalmente a deficiência intelectual manifesta-se antes dos 18 anos de idade e caracteriza-se, sobretudo por alterações no desenvolvimento das funções cognitivas (raciocínio, memória, atenção, juízo), da linguagem, das habilidades motoras e da socialização. Causas de tais deficiências podem ser diversas e decorrente de múltiplos fatores.

Existem causas genéticas e causas relacionadas a problemas no parto e na gestação como: complicações durante a gravidez (rubéola, uso de drogas, abuso de álcool, desnutrição materna), problemas ao nascimento (prematuridade, falta de oxigênio, traumatismos) e ainda doenças e condições que afetam a saúde, como sarampo, meningite, desnutrição, exposição a metais pesados como chumbo e mercúrio, entre outras (LIMA, 2009).

As principais características da deficiência intelectual são a falta de concentração, a dificuldade em interagir e se comunicar e a baixa capacidade de compreensão linguística (não compreendem a escrita ou precisam de um sistema de aprendizado especial).

Em relação à área motora, há crianças que tem a deficiência intelectual em um nível leve e assim sendo, não apresentam quase diferenças significativas em comparação com crianças sem deficiência, porém é possível que elas apresentem alguma alteração na motricidade fina. Agora já nos casos mais graves, é possível que haja uma dificuldade motora mais notável, como dificuldades 
na coordenação, ao manipular objetos e também no equilíbrio do seu corpo, podendo inclusive começar a andar tardiamente (FLETCHER, 2009).

Já na área cognitiva, as crianças com deficiência intelectual podem mostrar uma certa dificuldade ao aprender conceitos abstratos, em ter a atenção voltada para o ensino, em memorizar o que é pedido e em resolver problemas em geral. Mesmo com essas dificuldades, os alunos com deficiência conseguem alcançar os mesmos objetivos que os outros alunos, porém, em alguns casos, com um pouco mais de lentidão.

As maiores dificuldades estão na concentração, memória e solução de problemas, o que torna o aprendizado mais lento. mas não os impede de atingir os objetivos. Quanto à área da comunicação, alguns alunos com deficiência intelectual tem uma certa dificuldade na comunicação, fazendo com que seja um pouco mais difícil suas relações, apresentando dificuldades para se expressar, dificultando assim que sejam compreendidas (CASTRO; ALMEIDA; FERREIRA, 2010).

Enquanto isso, na área socioeducacional, nas crianças com deficiência intelectual surge uma diferença entre a idade mental e a idade cronológica, por conta disso é importante deixar claro que para que haja uma melhor interação social, os alunos devem ser colocados em contato com crianças da mesma idade cronológica, uma vez que assim elas participam das mesmas atividades, aprendendo a se comportar, além dos valores e atitudes correspondentes a sua faixa etária.

Quando o aluno com deficiência colocado na mesma turma que crianças correspondentes à sua idade mental, ao invés de ajuda-las, pode causar efeito contrário, pois a criança irá se sentir inferior, o que afeta diretamente seu desenvolvimento psíquico-social. Não há uma regra para trabalhar com alunos em geral, tanto com deficiências quanto sem (LIMA, 2009).

Devemos ter em mente que cada aluno é um e que suas potencialidades, necessidades e conhecimentos ou experiências prévias devem ser levados sempre em consideração. Para Honora e Frizanco (2008, p. 107) “inseri-los no ambiente escolar tem como objetivo reforçar e facilitar o desenvolvimento das capacidades do indivíduo, fornecendo o apoio que ele precisa para superar as suas dificuldades".

\section{Considerações finais}


Se compreendermos a deficiência a partir desse modelo social, quando um estudante - tenha deficiência ou não - não consegue aprender, é preciso considerar que a origem do problema não está necessariamente nas características intelectuais, mas, sim, em possíveis barreiras presentes na escola. Na prática, quando alunos com hipótese ou diagnóstico de defíciência intelectual "não aprendem", nossa tendência é responsabilizá-los por isso. Por muito tempo, acreditou-se que a educação especial deveria ser organizada de forma paralela à educação comum e que esta seria a forma mais apropriada para garantir o direito à educação das pessoas com deficiência. No entanto, o desenvolvimento de estudos no campo da educação e a ampliação dos debates acerca dos direitos humanos mudaram essa lógica.

A ideia de que educação especial deve integrar a proposta pedagógica da escola regular está consolidada e assegurada por um amplo aparato legal, que garante a matrícula, em classes comuns, dos estudantes nas seguintes condições: alunos com transtornos globais do desenvolvimento, sendo aqueles que apresentam um quadro de alterações no desenvolvimento psicomotor, comprometimento nas relações sociais, na comunicação ou estereotipias motoras. Incluem-se nessa definição alunos com autismo clássico, síndrome de Asperger, síndrome de Rett, transtornos desintegrativos da infância e transtornos invasivos sem outra especificação.

O estudo revelou a complexidade do processo de inclusão vivido pelas escolas, particularmente no que se refere ao currículo escolar e as práticas pedagógicas para o ensino aprendizagem dos alunos com deficiência intelectual. Mostrou-se também que um dos maiores obstáculos para atender adequadamente esses alunos em sala de aula comum paira na falta de conhecimentos dos professores.

Pode-se concluir que a escola atua como elemento básico do processo de autonomia e integração social das pessoas com deficiência intelectual. Perceber onde estamos e para onde queremos ir é fundamental para realizarmos esse percurso. Nesse sentido, não se deve parar a busca por mecanismos de melhoria do ensino e da promoção desses alunos. E os professores não podem parar de buscar formação e troca de saberes para que se concretizem mediações pedagógicas que favoreçam o processo de ensino-aprendizagem dos alunos com deficiência intelectual, assim como dos demais alunos. Cada ser humano, inclusive as crianças são seres únicos, individualizados. As crianças com Deficiência Intelectual merecem um olhar mais atento, pois as mesmas têm limitações, necessidades diferentes demais, principalmente a bagagem intelectual que elas 
carregam. É necessário que seja levado em conta que mesmo pequenas, elas possuem autonomia para realizar suas atividades de forma individual.

A pessoa portadora da deficiência intelectual precisa ter um apoio pedagógico, atenção especial, além de adequações nos seus currículos, porém mesmo com essas dificuldades é essencial lembrar sempre que eles são capazes, precisam sim de intervenções, mas o que faz mais diferença em sua evolução é ter pessoas que acreditem nelas.

A educação é o ato de introduzir os mais jovens em um mundo que os precede e está em constante mudança, configura-se um desafio constante: olharmos criticamente nossos pensamentos e ações para responder à questão: como estou apresentando o mundo comum para os recémchegados no espaço público?

A principal norma da inclusão escolar é que as escolas precisam detectar as dificuldades dos alunos e possam promoverem a eles uma educação de qualidade, assim como para os alunos sem deficiência, através da modificação organizacional, do currículo de aprendizado apropriado, estratégias de ensino e aprendizagem, entre outras ferramentas educacionais.

Ainda nos dias atuais não são todas as pessoas deficientes intelectuais que conseguem se incluir na sociedade, porém mesmo com essa dificuldade, para muitos isso já é uma realidade, superando os preconceitos e barreiras. Assim, é possível que as pessoas entendam que há diversidades, mas não há diferenças entre os seres humanos, fazendo com que aos poucos a sociedade se torne igualitária.

A deficiência, aos poucos, está fazendo parte da vida das pessoas de uma forma positiva gerando mais oportunidades a todos, e promovendo o real sentido da palavra inclusão. Não devemos ignorar ou tentar nos desvencilhar do mundo de diversidades, já que elas estão presentes por todos os lados.

\section{Referências}

ALVES, D. O.; GOTTI, M. O. O. Atendimento educacional especializado: concepção, princípios e aspectos organizacionais. In: BRASIL. Ministério da Educação. Ensaios pedagógicos. Brasília: MEC/SEESP, 2006. p. 267-272.

BATISTA, C. A. M.; MANTOAN, M. T. E. Atendimento educacional especializado em deficiência mental. In: BRASIL. Ministério da Educação. Secretaria de Educação Especial. 
Formação continuada a distância de professores para o atendimento educacional especializado: deficiência mental. Elaboração de Adriana L. Limaverde Gomes et al. Brasília: MEC/SEED/SEESP, 2007. p. 13-42.

BATISTA, M. W.; ENUMO, S. R. F. Inclusão escolar e deficiência mental: análise da interação social entre companheiros. Estudos de Psicologia, Natal, v. 9, n. 1, p. 101-111, 2004.

CASTRO, J. C. V.; ALMEIDA, M. J. M.; FERREIRA, V. Q. Os benefícios das intervenções pedagógicas para o desenvolvimento cognitivo do estudante com déficit intelectual. Anais das Jornadas de Pós-Graduação da Faculdade Integrada Brasil Amazônia - FIBRA, Belém, n. 3, p. 21-33, set. 2010 .

DENZIN, N.; LINCOLN, Y. Handbook of Qualitative Research. London: Sage Publication Inc, 2000.

DIAS, M. C. Atendimento educacional especializado complementar e a deficiência intelectual: considerações sobre a efetivação do direito à educação. Dissertação (Mestrado) Universidade de São Paulo, São Paulo, 2010.

FLETCHER, J. M. Transtornos de aprendizagem. Porto Alegre: Artmed, 2009.

HONORA, M.; FRIZANCO, M. L. Esclarecendo as Deficiências: aspectos teóricos e práticas para contribuir com uma sociedade inclusiva. São Paulo: Ciranda Cultural Editora e Distribuidora Ltda., 2008.

KÖCHE, J. C. Fundamentos de Metodologia Científica: teoria da ciência e iniciação à pesquisa. 29. ed. Petrópolis: Vozes, 2011.

LIMA, S. R. Escolarização da pessoa com deficiência intelectual: terminalidade específica e expectativas familiares. Tese (Doutorado) - Universidade Federal de São Carlos, São Carlos, 2009.

MANTOAN, M. T. E. A integração de pessoas com deficiência. São Paulo: Memnon. SENAC, 1997.

MANTOAN, M. T. E. Inclusão escolar: O que é? Por quê? Como fazer? São Paulo: Moderna, 2006.

MARCONI, M. A.; LAKATOS, E. M. Fundamentos de metodologia científica. 7. Ed. São Paulo: Atlas, 2010.

PAÍN, S. Diagnóstico e tratamento dos problemas de aprendizagem. Porto Alegre: Artes Médicas, 1985. 
PALANGANA, I. C. Desenvolvimento e aprendizagem em Piaget e Vygotsky: a relevância do social. São Paulo: Summus, 2001.

RIBEIRO, S. C. M. Inclusão social dos jovens com deficiência mental: o papel da formação profissional. Dissertação (Mestrado) - Escola Superior de Educação de Paula Frassinett, Porto, 2009.

ROSSATO, S. P. M.; LEONARDO, N. S. T. A deficiência intelectual na concepção de educadores da educação especial: contribuições da psicologia históricas culturais. Revista Brasileira de Educação Especial, Marília, v. 17, n. 1, p. 71-86, jan./abr. 2011.

SÁNCHEZ, J. G. Dificuldades de aprendizagem e intervenção psicopedagógica. Porto Alegre: Artmed, 2008.

SHANK, G. Qualitative Research. A Personal Skills Aproach. New Jersey: Merril Prentice Hall. 2002. 